\title{
HYDROCHEMICAL AND SEDIMENT DATA FOR THE OLD LEAD BELT, SOUTHEASTERN MISSOURI--1988-89
}

U.S. GEOLOGICAL SURVEY

Open-File Report 91-211

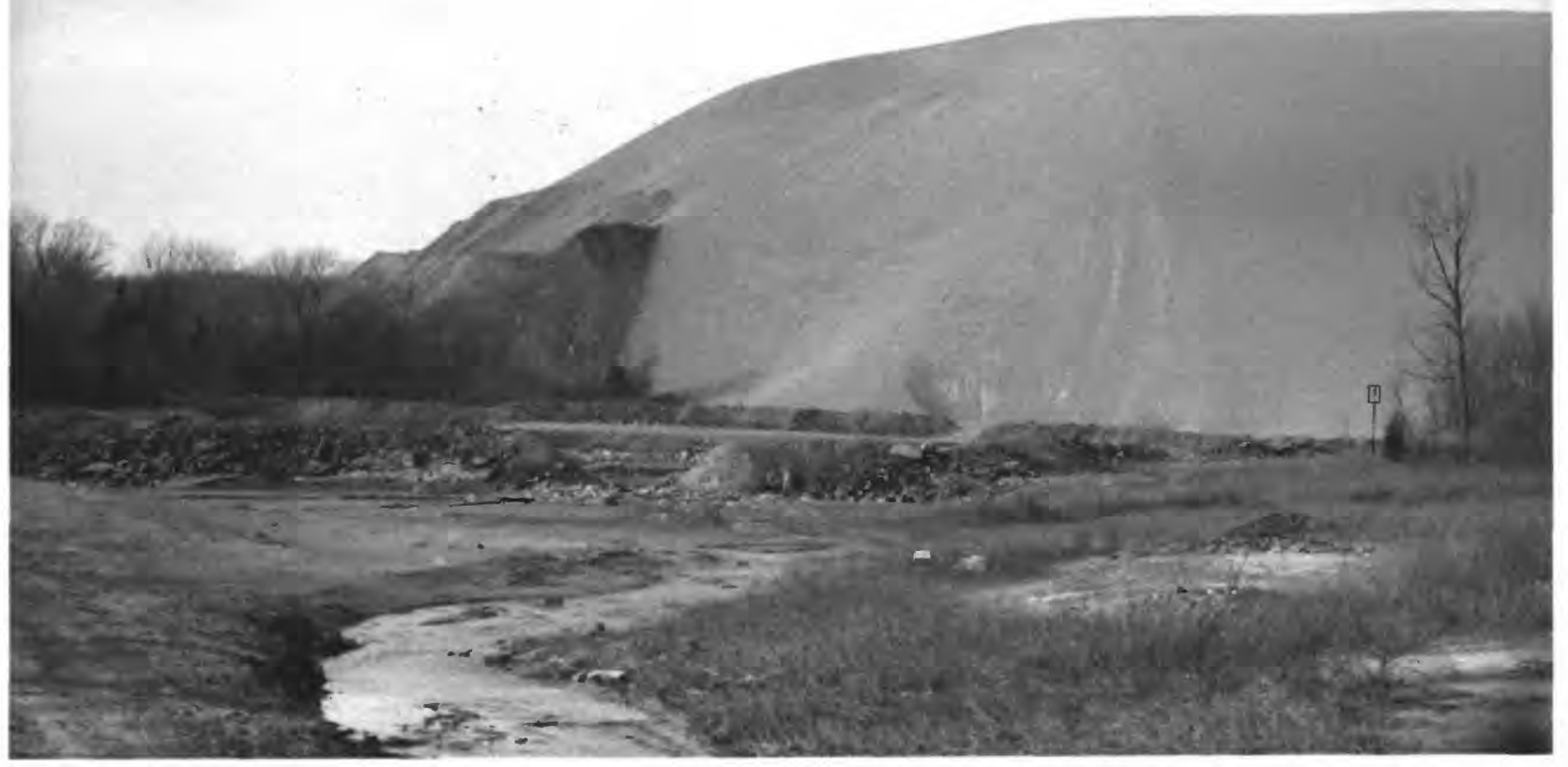

Prepared in cooperation with the MISSOURI DEPARTMENT OF NATURAL RESOURCES, LAND RECLAMATION COMMISSION

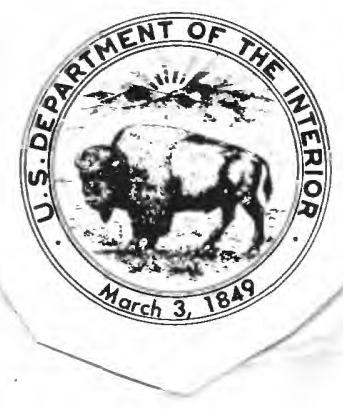




\section{HYDROCHEMICAL AND SEDIMENT DATA FOR THE OLD LEAD BELT, SOUTHEASTERN MISSOURI--1988-89}

By B.J. Smith and J.G. Schumacher

U.S. GEOLOGICAL SURVEY

Open-File Report 91-211

Prepared in cooperation with the

MISSOURI DEPARTMENT OF NATURAL RESOURCES, LAND RECLAMATION COMMISSION

Rolla, Missouri

1991 


\section{U.S. DEPARTMENT OF THE INTERIOR}

MANUEL LUJAN, JR., Secretary

U.S. GEOLOGICAL SURVEY

Dallas L. Peck, Director

For additional information write to:

District Chief

U.S. Geological Survey

1400 Independence Road

Mail Stop 200

Rolla, Missouri 65401
Copies of this report can be purchased from:

U.S. Geological Survey Books and Open-File Reports Section Federal Center, Building 810

Box 25425

Denver, Colorado 80225 


\section{CONTENTS}

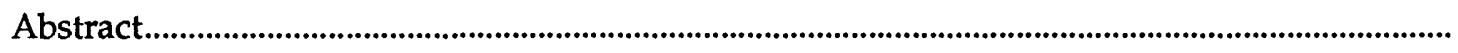

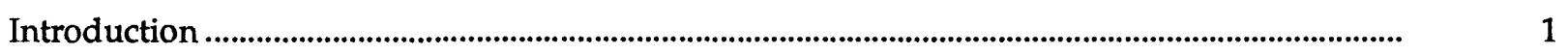

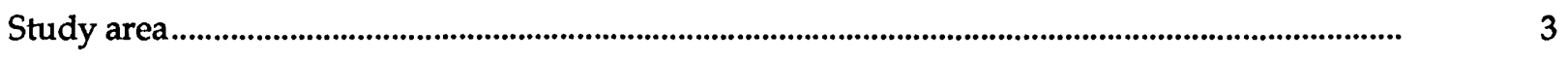

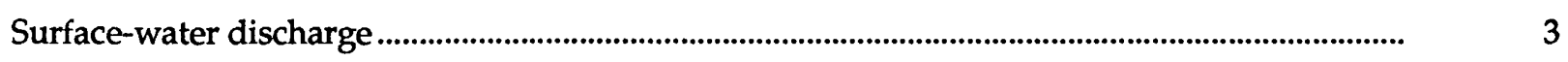

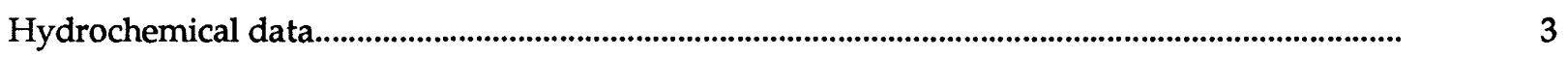

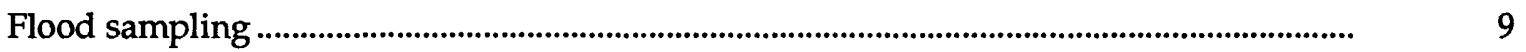

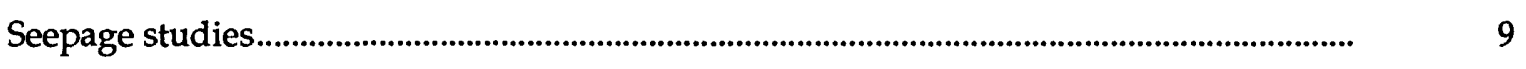

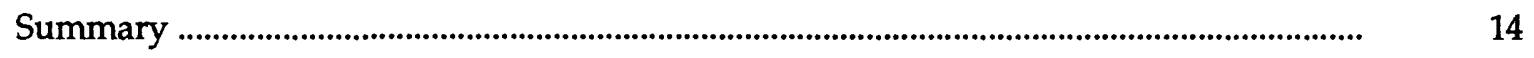

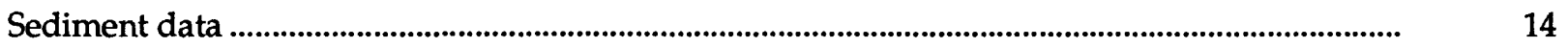

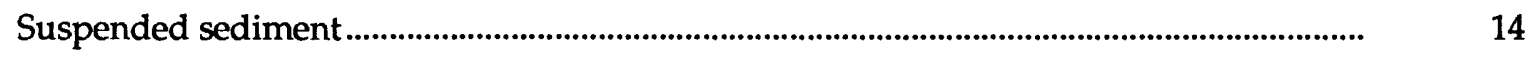

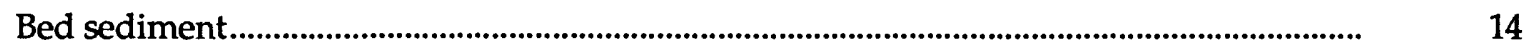

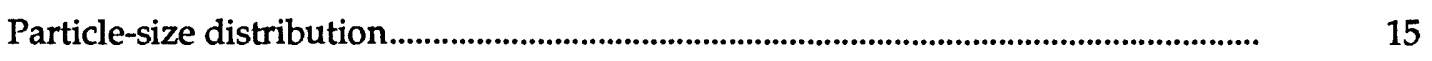

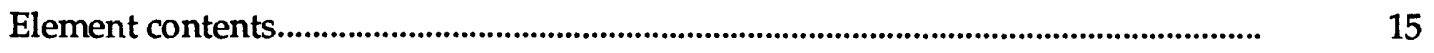

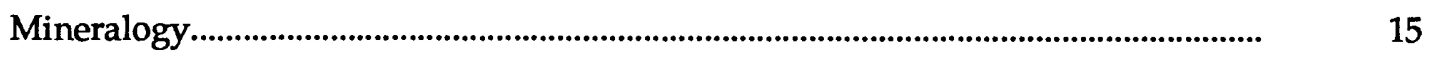

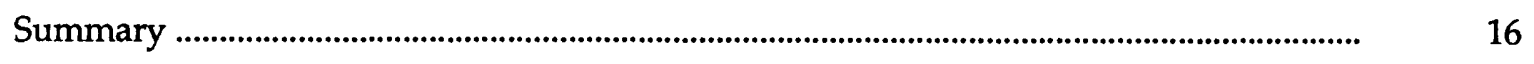

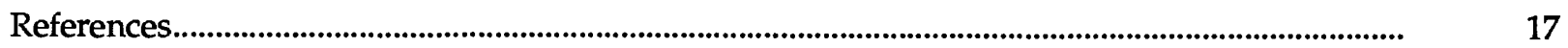




\section{ILLUSTRATIONS}

Page

Figure 1. Map showing mined areas in the Old Lead Belt.................................................. 2

2. Map showing location of study area, continuous-record gaging stations, water-quality sampling sites, and sediment sampling sites

3-6. Hydrographs showing:

3. Daily mean discharge for the Big River at Irondale .......................................

4. Daily mean discharge for the Big River below Desloge ............................... 6

5. Daily mean discharge for the Flat River at National tailings pile .............. $\quad 7$

6. Daily mean discharge for the Big River near Richwoods............................. 8

7-9. Maps showing:

7. Results of seepage run in the Big River upstream from State Highway 8 to the Leadwood Public Access, September 13, 1989

8. Results of seepage run in the Flat River, September 13, 1989 .....................

9. Results of seepage run in the Big River from the Leadwood Public Access to the Big River below Desloge, November 6-8, 1989.

\section{TABLES}

Table 1. Water-quality and sediment sampling sites

2. Daily mean discharge for the Big River below Desloge

3. Daily mean discharge for the Flat River at National tailings pile.

4. Water-quality data

5. Water-quality data for flood samples

6. Particle-size distribution of suspended sediment for flood samples.

7. Total element contents of suspended sediment for flood samples (inductively coupled plasma)

8. Water-quality sampling sites for seepage runs in the Big River . 


\section{TABLES--Continued}

Table 9. Water-quality data for seepage run sites in the Big River upstream from State Highway 8 to the Leadwood Public Access, September 13, 1989.

10. Water-quality data for seepage run sites in the Big River from the Leadwood Public Access to the Big River below Desloge, November 6-8, 1989

11. Particle-size distribution of bed sediment

12. Particle-size distribution of bed sediment for seepage run sites in the Big River.

13. Total element contents of bed sediment (inductively coupled plasma).

14. Total element contents of bed sediment for seepage run sites (inductively coupled plasma)

15. Semiquantitative emission spectrograph analyses of bed sediment

16. Semiquantitative emission spectrograph analyses of bed sediment for seepage run sites.

17. Mineralogy of bulk samples from bed sediment

18. Mineralogy of bulk samples from bed sediment for seepage run sites.................

19. Weight percentages of heavy mineral concentrates from bed sediment .............. 80

20. Mineralogy of C-2 fraction from bed sediment ......................................................

21. Mineralogy of C-2 fraction from bed sediment for seepage run sites .................... 83

22. Semiquantitative emission spectrograph analyses of $\mathrm{C}-3$ fraction from bed sediment

23. Semiquantitative emission spectrograph analyses of C-3 fraction from bed sediment for seepage run sites..

24. Mineralogy of C-3 fraction from bed sediment

25. Mineralogy of C-3 fraction from bed sediment for seepage run sites.

26. Phase associations of bed sediment (scanning electron microscope) 


\section{CONVERSION FACTORS AND VERTICAL DATUM}

\section{Multiply}

acre

mile

square mile

foot

ton, short

foot per second

gallon

pound

cubic foot per second
By

0.4047

1.609

2.590

0.3048

0.9072

0.3048

3.785

0.4536

0.02832
To obtain

hectare

kilometer

square kilometer

meter

megagram

meter per second

liter

kilogram

cubic meter per second

To convert degrees Celsius $\left({ }^{\circ} \mathrm{C}\right)$ to Fahrenheit $\left({ }^{\circ} \mathrm{F}\right)$, use the following:

$$
{ }^{\circ} \mathrm{F}=\frac{9}{5}{ }^{\circ} \mathrm{C}+32
$$

Sea level: In this report, "sea level" refers to the National Geodetic Vertical Datum of 1929-a geodetic datum from a general adjustment of the first-order level nets of the United States and Canada, formerly called Sea Level Datum of 1929. 


\title{
HYDROCHEMICAL AND SEDIMENT DATA FOR THE OLD LEAD BELT, SOUTHEASTERN MISSOURI-1988-89
}

\author{
By \\ B.J. Smith and J.G. Schumacher
}

\begin{abstract}
This report presents hydrochemical and sediment data collected during an investigation of the Old Lead Belt in southeastern Missouri from 1988 to 1989 . The data consist of water-quality analyses of samples collected from 12 sites, which includes 6 sites on the Big and Flat Rivers, 5 seepage sites related to tailings piles, and discharge from an abandoned exploration drill hole. Also included in this report are analyses of flood samples and the results of seepage runs on the Big and Flat Rivers. Analyses of bed sediment samples are included from all sites except discharge from the drill hole.
\end{abstract}

Specific conductance values in water samples from the Big River ranged from 209 to 690 microsiemens per centimeter at 25 degrees Celsius, from the Flat River-241 to 990 microsiemens per centimeter, and from seepage sites478 to 1,540 microsiemens per centimeter. The largest dissolved sulfate concentration detected was 850 milligrams per liter at a seepage site. Most trace-element concentrations were largest at seepage sites, including dissolved zinc, 18,000 micrograms per liter, dissolved cobalt, 610 micrograms per liter, and dissolved lead, 80 micrograms per liter.

Total trace-element contents in bed sediment increased from the upstream reaches of the Big and Flat Rivers throughout the mining area and decreased downstream from the study area. The largest lead content detected was 38,000 micrograms per gram at a seepage site. The largest zinc content was more than 100,000 micrograms per gram at a seepage site. Most trace elements were associated with either the oxide or sulfide phase in the bed sediment.

\section{INTRODUCTION}

Lead was discovered in southeastern Missouri about 1700 (Kramer, 1976). Before the mid-1860's, lead mining consisted of individual, shallow workings scattered throughout the area. The St. Joseph Lead Co. acquired 964 acres in 1864 and began mining at Bonne Terre. In 1869 diamond-bit core drilling indicated lead deposits underlying Bonne Terre, Desloge, Flat River, Leadwood, and Elvins (fig. 1). From the late $1800^{\prime}$ s to the early 1900 's as many as 15 companies operated mines in the area. By 1933 the St. Joseph Lead Co. had acquired the properties of the other mining companies in the area. The St. Joseph Lead Co. mined at Bonne Terre from 1864 to 1961, at Desloge from 1929 to 1958, and at Leadwood from 1915 to 1962 (U.S. Geological Survey and Missouri Division of Geology and Land Survey, 1967). The mines were gradually shut down during the late 1950's and early 1960's as the ore deposits were depleted and production from other mines in the State exceeded that of the Old Lead Belt. In October 1972, the Federal Division of the St. Joseph Lead Co., the last mining operation in the Old Lead Belt, closed (Kramer, 1976).

A Statewide assessment of water quality was completed in non-coal mining areas during 1988 to determine those areas where mining had affected water resources (Smith, 1988); therefore, a hydrologic investigation of the Old Lead Belt was begun by the U.S. Geological Survey in cooperation with the Missouri Department of Natural Resources, Land Reclamation Commission. This report contains data collected during the investigation from 1988 to 1989. Samples were collected and analyzed to assess the effects of mining on the quality of surface water in the area, including dissolved trace-element concentrations, and to determine the particle-size distribution, total-element content, and mineralogy of suspended and bed sediment.

Support of this study by the U.S. Department of the Interior, Office of Surface Mining Reclamation and Enforcement is acknowledged. However, the contents of this publication do not necessarily reflect the views and policies of this agency. 


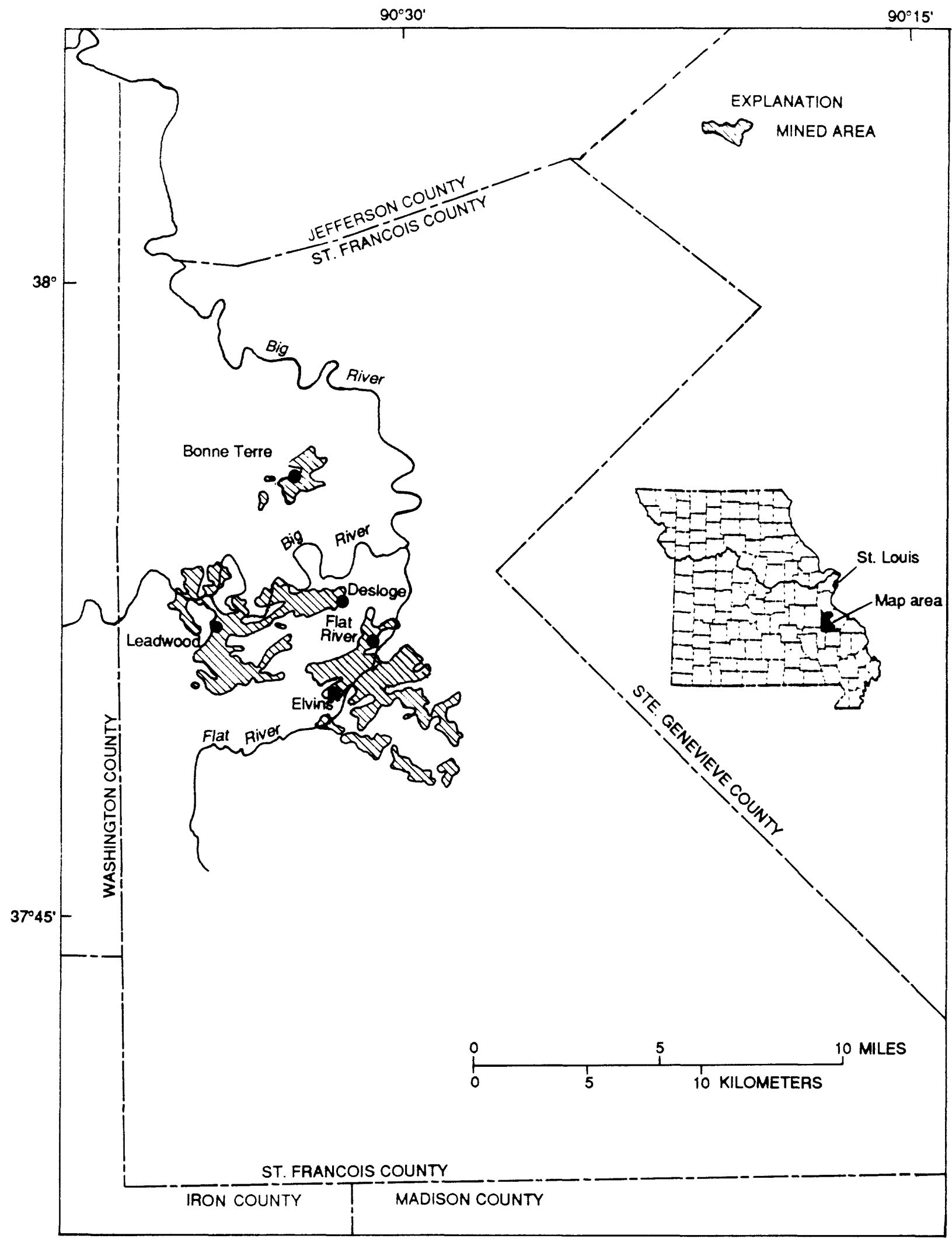

Figure 1.--Mined areas in the Old Lead Belt (modified from Association of Missouri Geologists, 1969). 


\section{STUDY AREA}

The Old Lead Belt is in southeastern Missouri, about 70 miles south of St. Louis (fig. 1). It encompasses about 110 square miles located entirely within St. Francois County.

The Old Lead Belt is located within the Salem Plateau of the Ozark Plateaus physiographic province (Fenneman, 1938). The topography is hilly with several hundred feet of relief. Altitudes range from about 700 to 1,000 feet. The main stream in the area is the Big River, which flows eastward and northward through the study area. The largest tributary to the Big River is the Flat River. The Big River is a perennial, gaining stream, whereas Flat River is an intermittent stream (Kramer, 1976) that probably loses water to the groundwater system immediately after dry periods. The study area in this report (fig. 2 ) includes sampling sites (table 1, at the back of this report) on the Big and Flat Rivers both upstream and downstream from the mined areas in the Old Lead Belt.

About 250 million tons of tailings were produced in the Old Lead Belt and were placed directly on the land surface in large piles covering hundreds of acres (Kania and Nash, 1986). Some of the largest tailings areas are abandoned settling ponds that were formed by damming small stream valleys. Others were formed by construction and subsequent filling of ring-shaped dikes along streams. The Big River basin is estimated to contain 3,000 acres of tailings (Kania and Nash, 1986). There are six major tailings piles in the area that contain unremoved particles of ore minerals that contribute cadmium, iron, lead, sulfate, zinc, and possibly copper to the environment (Smith, 1988). Physical mechanisms of contamination are dispersal of tailings by wind and runoff and slumping of tailings into streams and subsequent transport downstream. Chemical mechanisms of contamination would include the oxidation and dissolution of sulfide minerals, and subsequent aqueous transport to the streams.

\section{SURFACE-WATER DISCHARGE}

Discharge was determined on the Big and Flat Rivers at sites 1, 6, 11, and 12 (fig. 2). Gages at sites 1 (07017200) and $12(07018100)$ are long term, continuous-record gages operated by the U.S. Geological Survey. Gages at sites $6(07017260)$ and $11(07017350)$ were installed for this study. Stream stages (gage height) were continually recorded by digital recorders every 15 minutes. The stage-discharge relation for the gaged sites was developed by current-meter measurements made at varying stages and plotted on a log$\log$ scale to create a rating table. When the stage-discharge relation changed because of a change in the physical features that form the control or changed temporarily because of debris on the control, the daily mean discharge was computed by the shifting-control method. Using this method, correction factors based on individual discharge measurements were applied to the gage height. Daily mean discharge data for sites 1 and 12 are available in Waite and others $(1989,1990)$ and for sites 6 and 11 are listed in tables 2 and 3 , at the back of this report. Hydrographs for the four gaged sites are shown in figures 3 to 6 .

\section{HYDROCHEMICAL DATA}

Water-quality samples were collected at 12 sites quarterly from January 1988 to September 1989 (fig. 2). The sites included those on the Big River (sites 1, 3, 6, and 12) and Flat River (sites 7 and 11), seeps from tailings piles (sites 2,5,9, and 10), discharge from an abandoned exploration drill hole (site 4), and a site at the base of a tailings pile (site 8). Locations of sampling sites are listed in table 1 and shown on figure 2. Water-quality data for all sites are listed in table 4 (at the back of this report).

Discharge measurements were made according to methods described by Buchanan and Somers (1969). Water-quality samples were collected according to methods described by Edwards and Glysson (1988). 


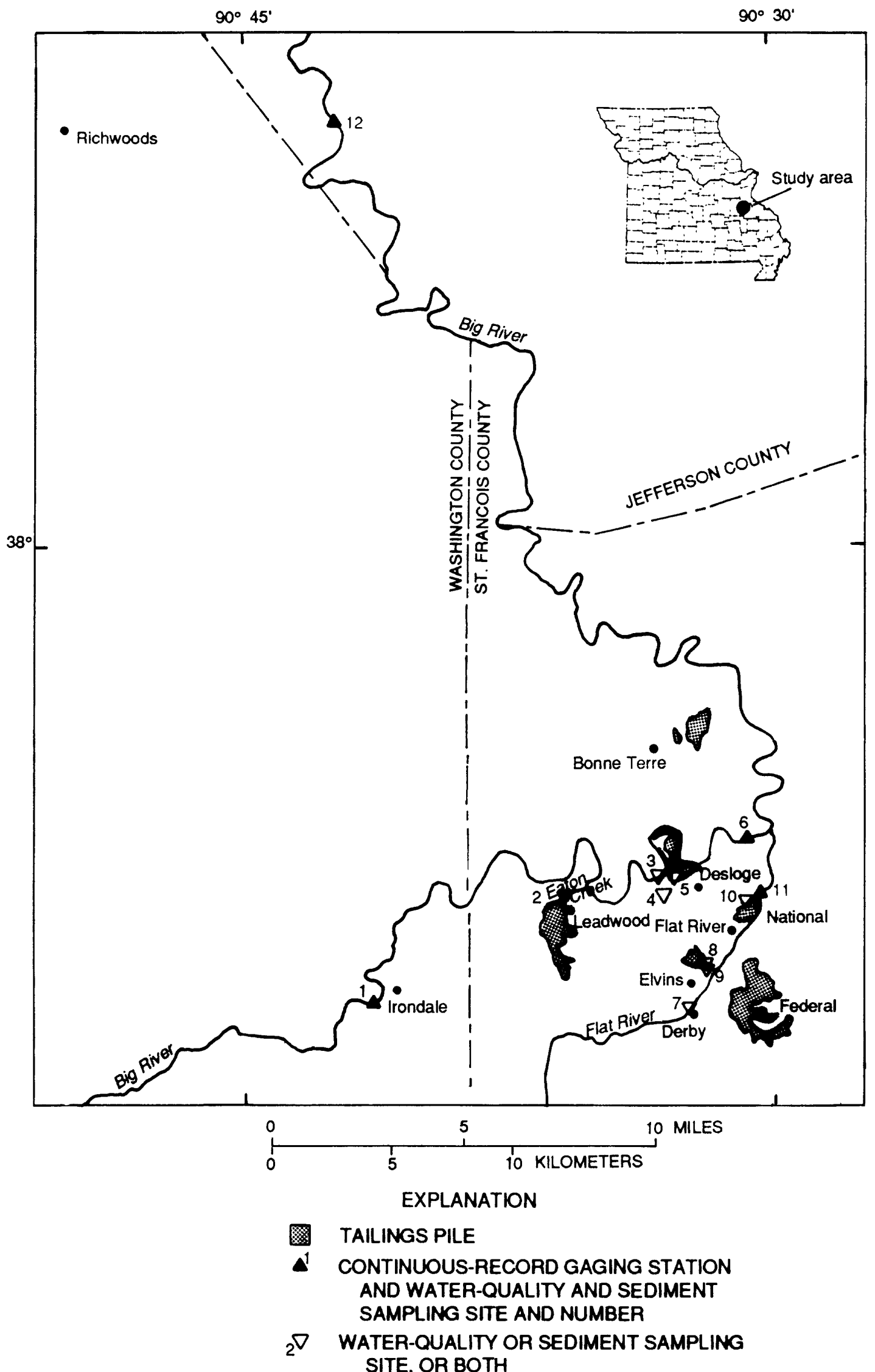

Figure 2.--Location of study area, continuous-record ganging stations, water-quality sampling sites, and sediment sampling sites.

4 


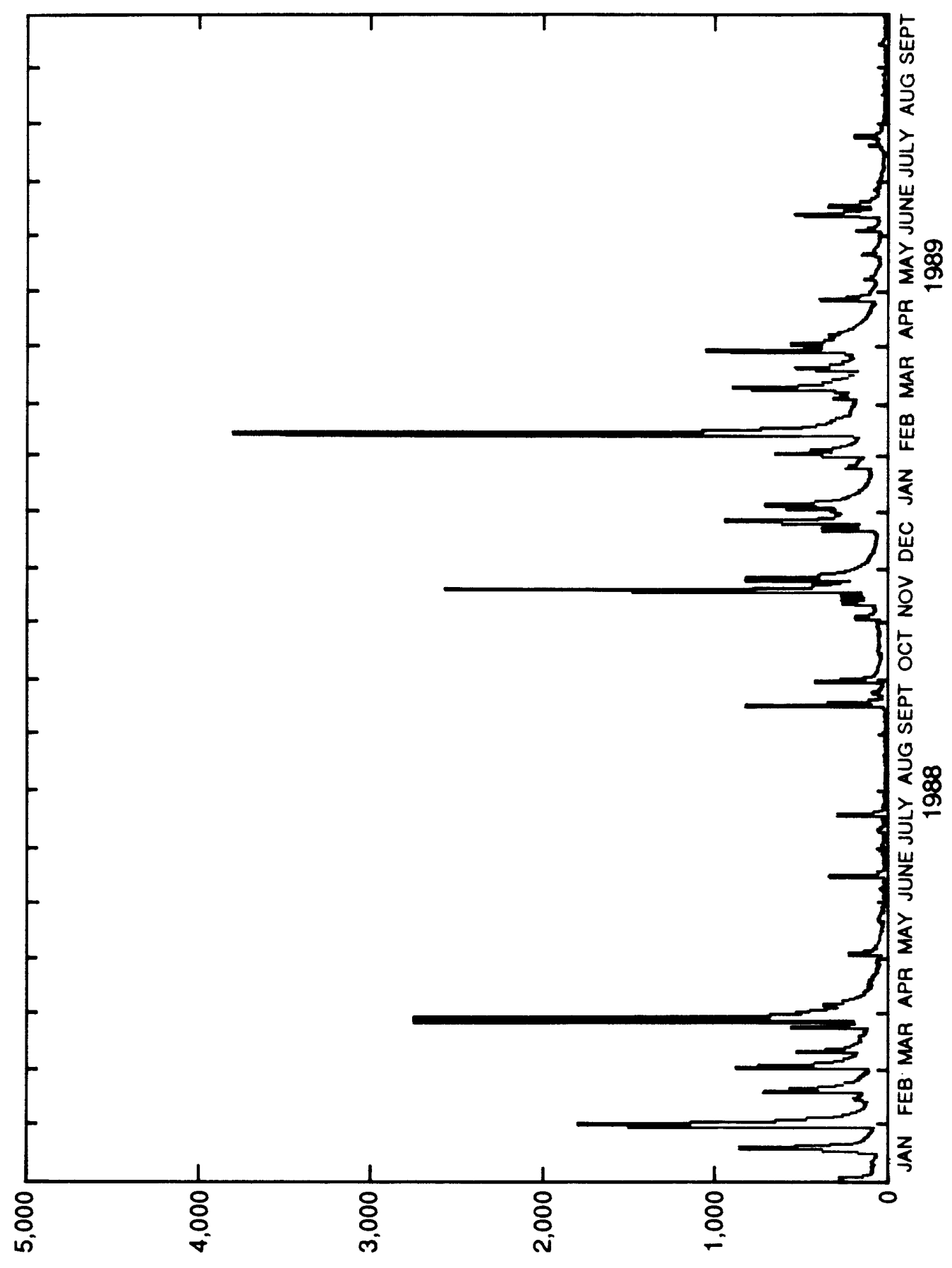

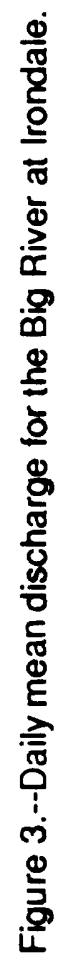

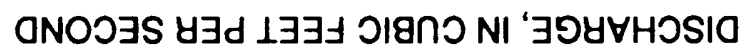




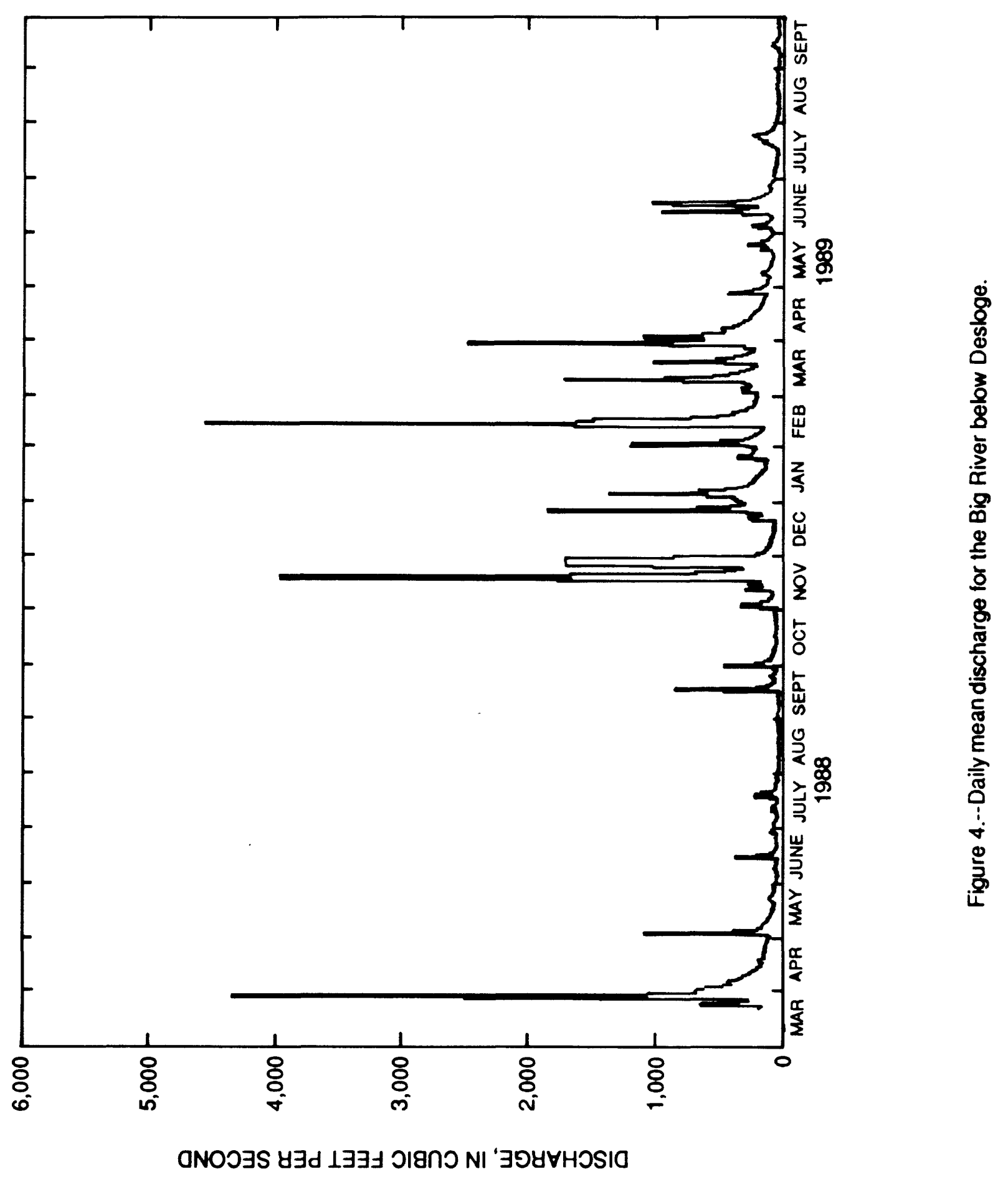




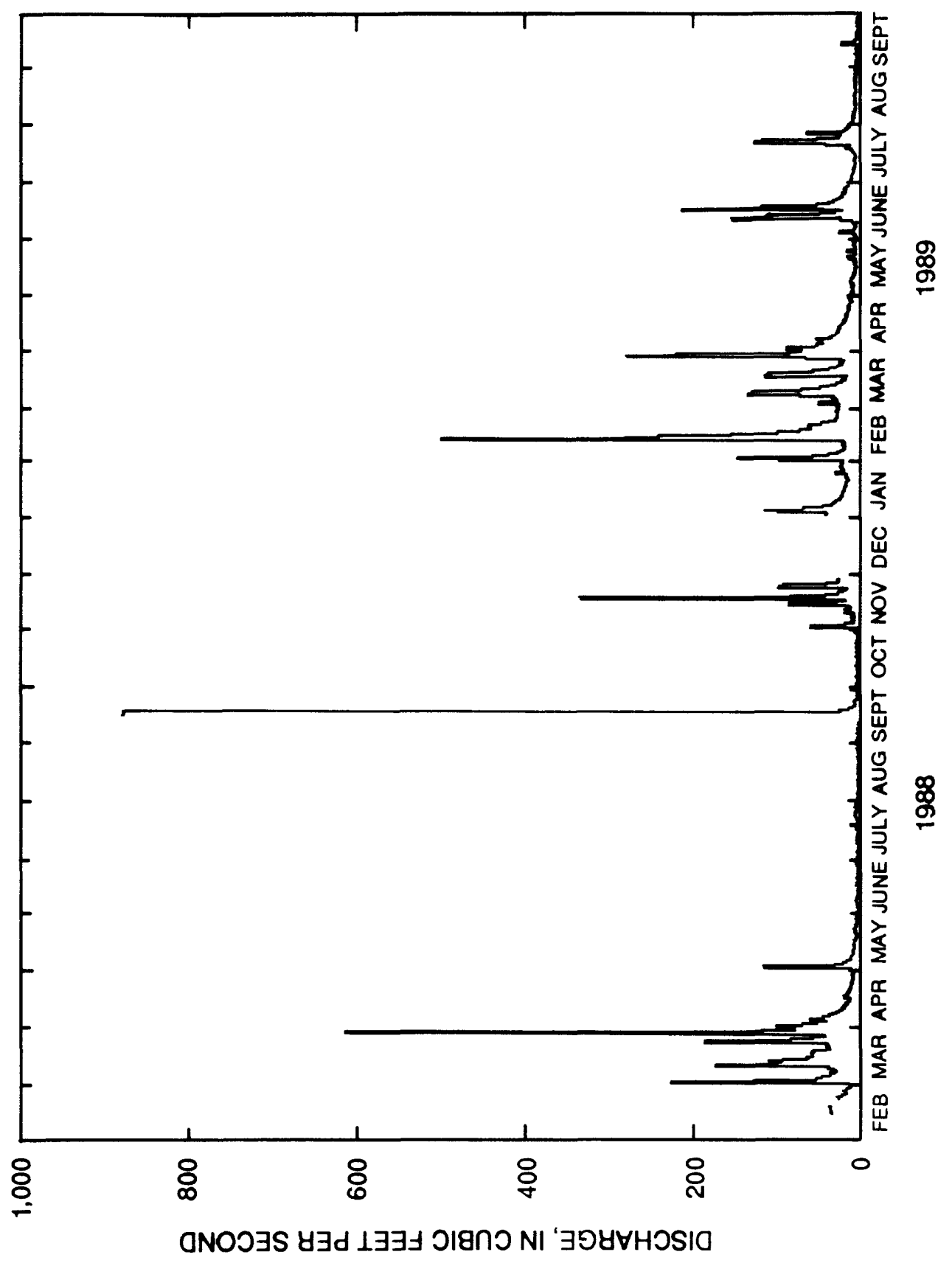

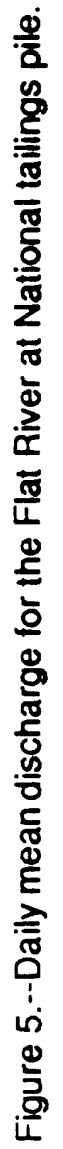




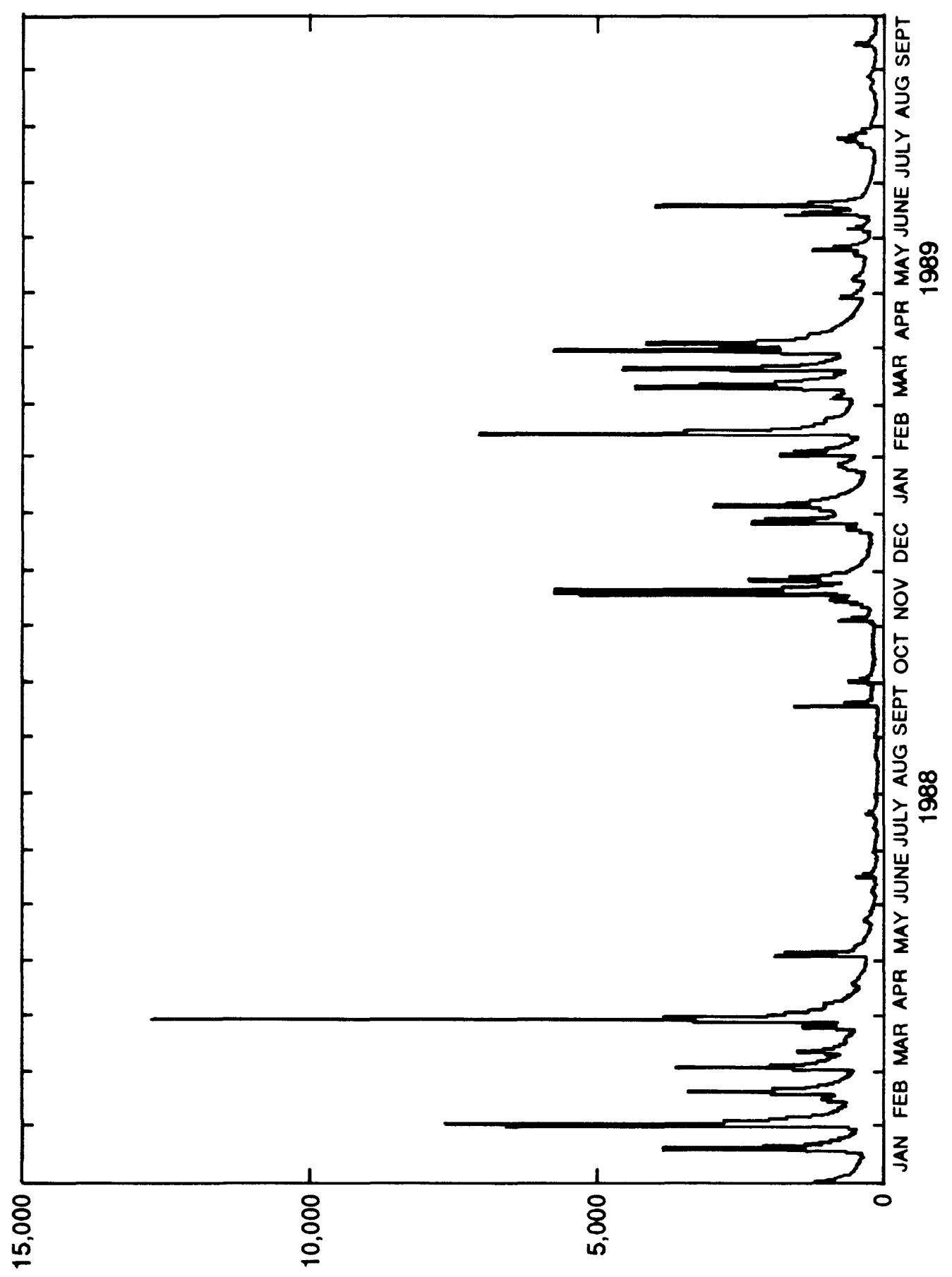

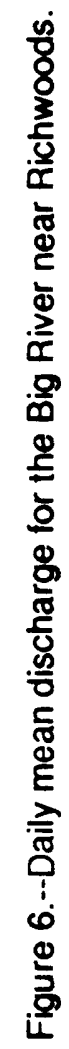

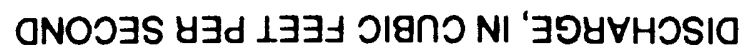


All samples were submitted to the U.S. Geological Survey national water-quality laboratory in Arvada, Colorado, for analysis. Samples were analyzed for inorganic constituents according to methods described by Fishman and Friedman (1989). Chemical constituents referred to as "dissolved" were determined from samples that were filtered at the time of sampling through a 0.1 micrometer membrane filter between leucite plates, using a peristaltic pump as the pressure source.

Values of specific conductance, $\mathrm{pH}$, water temperature, and alkalinity were determined at the time of sampling. Specific conductance was measured using a portable conductivity meter with temperature compensation designed to express readings in microsiemens per centimeter at 25 degrees Celsius. The potentiometric method was used to determine the $\mathrm{pH}$ value and alkalinity. The $\mathrm{pH}$ values were measured using a portable $\mathrm{pH}$ meter calibrated with standard buffers bracketing the expected sample $\mathrm{pH}$ value. Alkalinity was determined by incremental titration with 0.16 normal sulfuric acid to the bicarbonatecarbonic acid end point of approximately $\mathrm{pH}$ 4.5. Water temperature was measured using a thermistor attached to the $\mathrm{pH}$ meter.

\section{Flood Sampling}

Water-quality and suspended-sediment samples were collected at high flow at sites 6 and 11 (fig. 2). Water-quality samples were collected using a U.S. Geological Survey DH-48-TM sampler if the stream could be waded or a U.S. Geological Survey D-74-TM sampler with cable-and-reel suspension if the stream could not be waded. Samples were composited from at least seven vertical sections. Suspended-sediment samples were collected according to methods described by Guy and Norman (1970). Results of waterquality analyses of flood samples, including suspended-sediment concentrations, are in table 5 (at the back of this report). Particle-size distribution of suspended-sediment samples is in table 6 (at the back of this report).

Additional suspended-sediment samples were collected and placed in 1-gallon polyethylene containers. The sediment was allowed to settle in a darkened environment at room temperature for about 2 weeks. The settling time was determined using Stokes law (Guy, 1969). Excess water was drawn off through an 18-gauge stainless steel needle with nylon tubing attached that had been inserted into the container 2 centimeters above the bottom of the container so as not to disturb any of the settled sediment. The container was then dried at 60 degrees Celsius until the remaining water evaporated and the sediment was completely dry. The dried sediment was digested by nitric, hydrofluoric, and perchloric acids, and then analyzed for total-element contents by inductively coupled plasma by the U.S. Geological Survey, geochemistry laboratory, Denver, Colorado. Analyses were done according to methods described in Fishman and Friedman (1989). The results are shown in table 7 (at the back of this report).

\section{Seepage Studies}

Two seepage runs were made in the study area. The first was on September 13,1989, on the reach of the Big River upstream from State Highway 8 to the Leadwood Public Access (fig. 7) and also on the Flat River from Derby to the gaging station below the National tailings pile (fig. 8). The second seepage run was made November 6-8, 1989, on the Big River from the Leadwood Public Access to the Big River below Desloge (fig. 9). Discharge measurements were made to locate stream reaches where surface flow is lost to or gained from the subsurface and water-quality samples were collected to assess the effects of miningrelated discharges, such as discharge from abandoned drill holes and tailings piles, on the river systems. No measurable precipitation had fallen 7 to 14 days before each seepage run. Location of seepage sites on the Big River where water-quality analyses are available is given in tables 1 and 8 (at the back of this report). Water-quality analyses for the September seepage run are in table 9 (at the back of this report) and analyses for the November seepage run are in table 10 (at the back of this report). 

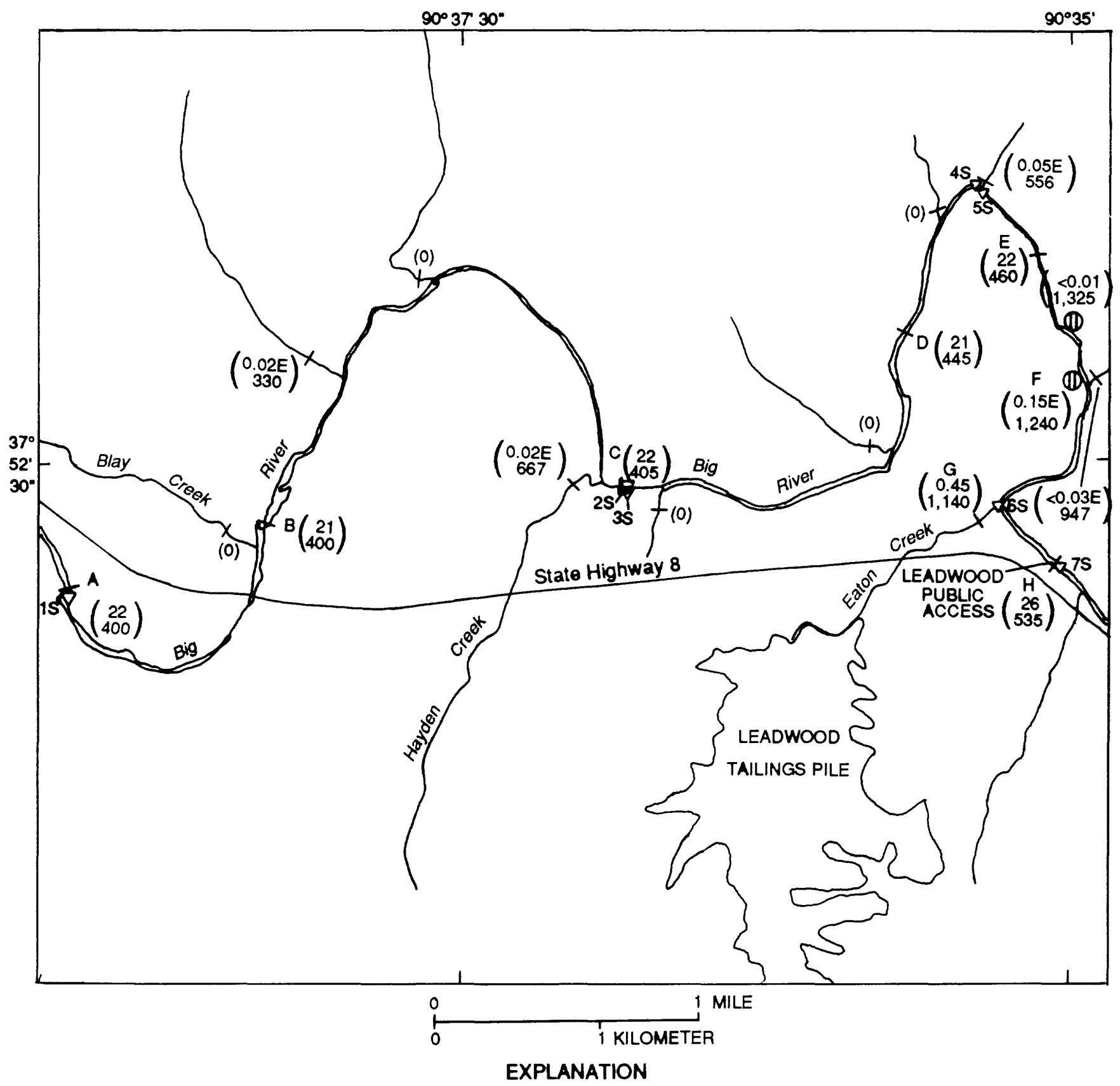
A STREAM MEASUREMENT SITE-- Letter refers to table 8 + and water-quality analysis in table 9
FDI SEEP MEASUREMENT SITE--Letter refers to table 8 and water-quality analysis in table 9
(22) Upper number is discharge, in cubic feet per second; lower number is specific conductance, in microsiomens per centimoter at 25 degrees Celsius; (0), no discharge present; $E$ following discharge value, estimated; $<$, less than

is $\nabla$ BED SEDIMENT SAMPLING SITE

Figure 7.--Results of seepage run in the Big River upstream from State Highway 8 to the Leadwood Public Access, September 13, 1989. 


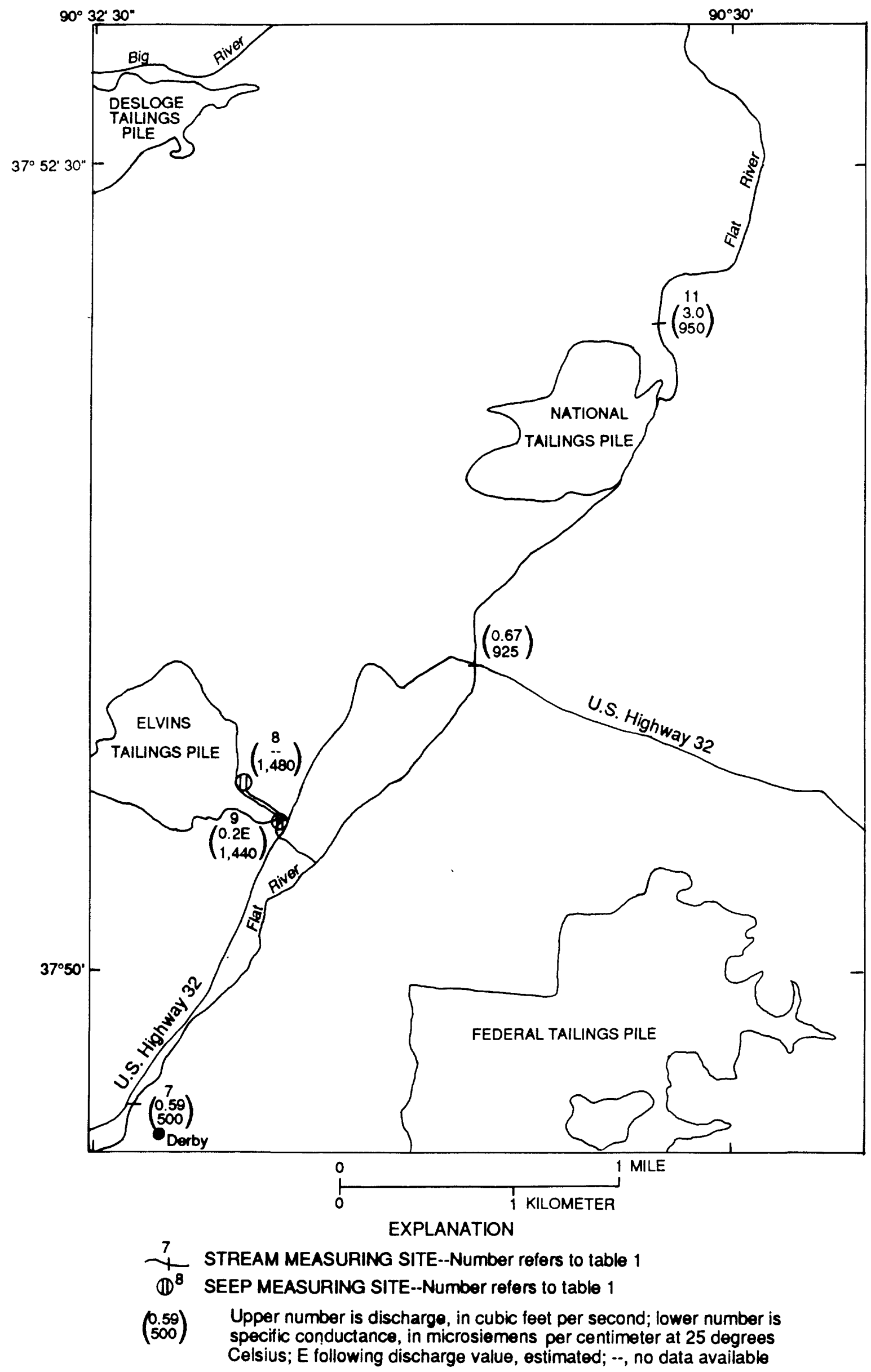

Figure 8.--Results of seepage run in the Flat River, September 13, 1989. 


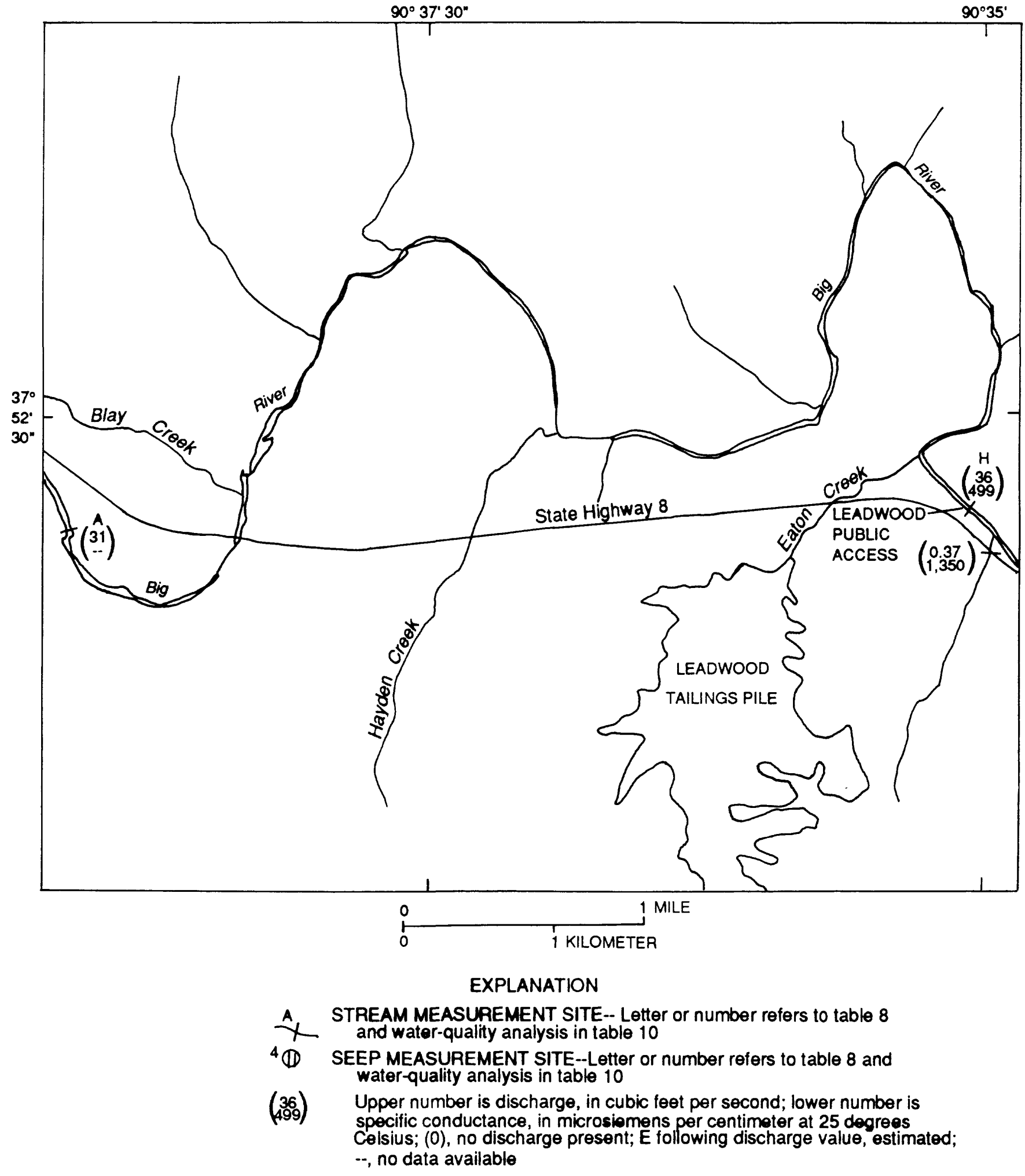

Figure 9.--Results of seepage run in the Big River from the Leadwood Public Access to the Big River below Desloge, November 6-8, 1989. 


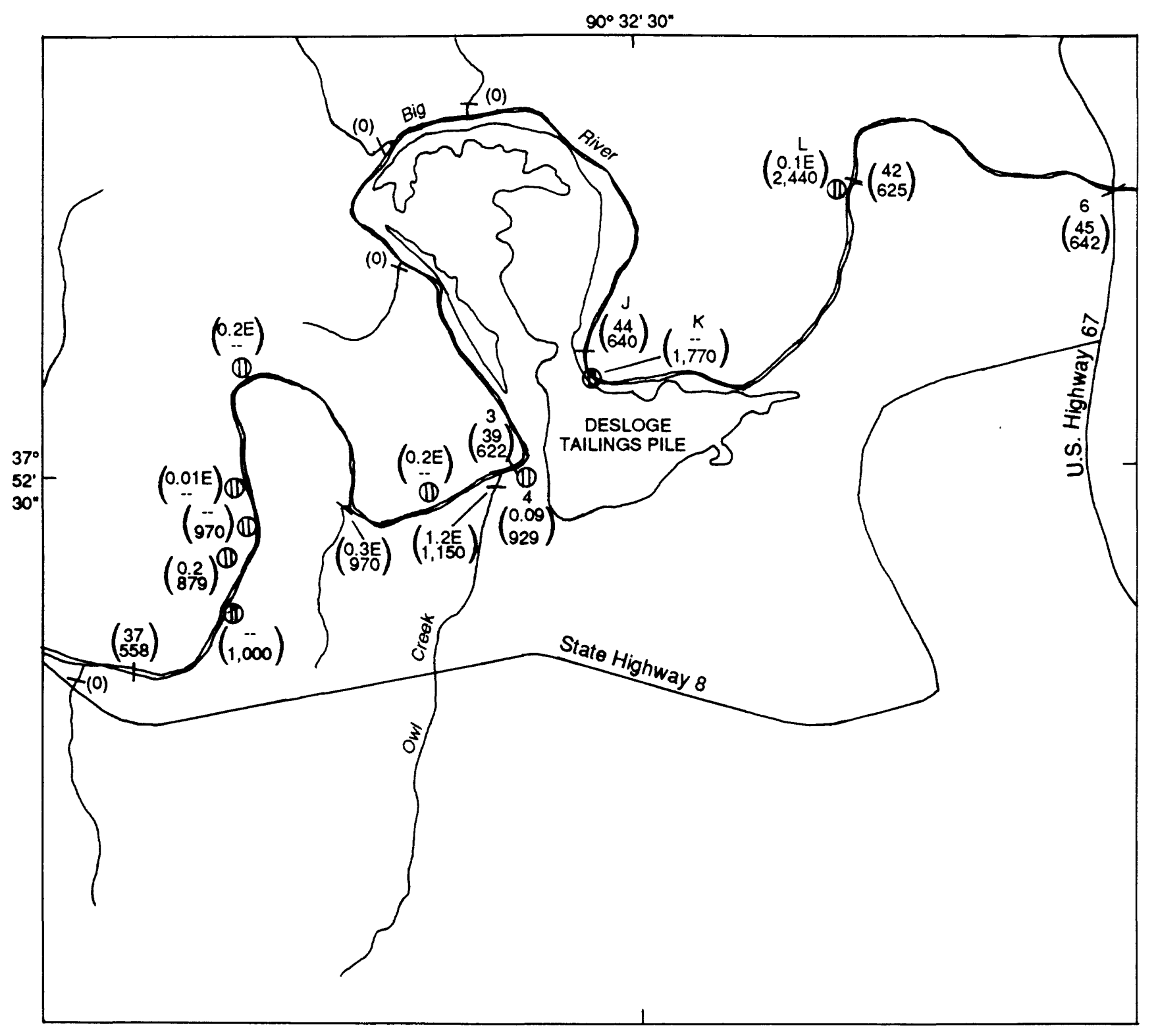

Figure 9.--Results of seepage run in the Big River from the Leadwood Public Access to the Big River below Desloge, November 6-8, 1989 -- Continued. 


\section{Summary}

At sites on the Big River (sites 1, 3, 6, and 12, fig. 2), specific conductance values ranged from 209 to 690 microsiemens per centimeter and on the Flat River (sites 7 and 11) from 241 to 990 microsiemens per centimeter. Dissolved sulfate concentrations for both rivers were 140 milligrams per liter or less, except at site 11. Dissolved cadmium, cobalt, and copper concentrations generally were less than the detection limit for each element at all river sites. Dissolved iron concentrations generally were less than 10 micrograms per liter, and dissolved lead concentrations generally were less than or equal to 10 micrograms per liter at all river sites, except for one sample from site 11 that had a dissolved lead concentration of 50 micrograms per liter. Dissolved zinc concentrations were 160 micrograms per liter or less for all river sites except at site 11 where they ranged from 110 to 400 micrograms per liter.

At seepage sites related to tailings piles (sites 2,5,9, and 10, fig. 2) and at the site at the base of a tailings pile (site 8), specific conductance values ranged from 478 to 1,540 microsiemens per centimeter, and dissolved sulfate concentrations ranged from 130 to 850 milligrams per liter. Dissolved cadmium concentrations generally were above the detection limit of 1 microgram per liter at sites 2,8 , and 9, where they ranged to 28 micrograms per liter. Dissolved cobalt concentrations were less than 100 micrograms per liter, except at sites 8 and 9, where they ranged to 610 micrograms per liter. Dissolved copper concentrations generally were less than the detection limit of 10 micrograms per liter. The maximum dissolved iron concentration was 60 micrograms per liter at site 8 . Dissolved lead concentrations were 80 micrograms per liter or less. Dissolved zinc concentrations ranged from about 50 to 18,000 micrograms per liter and were largest at site 8.

Discharge from the drill hole (site 4, fig. 2) had specific conductance values that ranged from 921 to 970 microsiemens per centimeter. Dissolved sulfate concentrations ranged from 250 to 270 milligrams per liter. Dissolved cadmium concentrations were 2 micrograms per liter or less. Dissolved cobalt concentrations ranged from 20 to 30 micrograms per liter. Dissolved copper concentrations were less than the detection limit of 10 micrograms per liter. Dissolved iron concentrations ranged from less than 3 to 19 micrograms per liter; dissolved lead concentrations ranged from 18 to 30 micrograms per liter. Dissolved zinc concentrations ranged from 170 to 310 micrograms per liter.

\section{SEDIMENT DATA}

\section{Suspended Sediment}

Suspended-sediment samples generally were collected quarterly at sites on the Big and Flat Rivers and at seepage sites 2, 9, and 10 beginning in September 1988. They were collected according to methods described by Guy and Norman (1970). Concentrations of suspended sediment were determined using methods described by Guy (1969) and are given in table 4.

\section{Bed Sediment}

Bed sediment was either collected quarterly from January 1988 to September 1989 or was collected three times during 1988 and 1989 at all sites shown in figure 2, with the exception of site 4 . Samples consisted of the upper 2 centimeters of sediment, which was removed in a plastic scoop. At each site, 3 transects, spaced about 150 feet apart, were made and 10 subsamples were collected along each transect, composited, and mixed thoroughly before analysis. About 10 to 20 pounds of sediment were collected at each site.

Bed sediment also was collected during the seepage run on the Big River, September 13, 1989. Sample collection sites are shown in figure 7. 


\section{Particle-Size Distribution}

Particle-size distribution of bed sediment was determined by sieve and pipet analysis by the U.S. Geological Survey sediment laboratory in Iowa City, Iowa. Size distributions were made according to methods described by Guy (1969). Results of these analyses for quarterly or triannual samples are listed in table 11 (at the back of this report). Results of analyses of samples from seepage run sites are listed in table 12 (at the back of this report).

\section{Element Contents}

Total element contents in bed sediment were determined by inductively coupled plasma at the U.S. Geological Survey geochemistry laboratory, Denver, Colorado. The samples underwent total digestion with hydrofluoric, nitric, and perchloric acids. Analyses were made according to methods described in Fishman and Friedman (1989). The analyses were made on the fine or clay/silt-size (less than 63 micrometers) and the coarse or sand-size (63 to 180 micrometers) fractions.

Results of the analyses for quarterly or triannual samples are listed in table 13 (at the back of this report). The results of the analyses for bed sediment collected during the seepage run are listed in table 14 (at the back of this report).

\section{Mineralogy}

Mineralogical analysis was done on bed sediment to confirm the presence of selected elements by semiquantitative emission spectrograph analyses by the U.S. Geological Survey, geochemistry laboratory, Denver, Colorado. Analyses were made according to methods described in Fishman and Friedman (1989). Analyses were made on the less than 45-micrometers and the less than 63-micrometers fractions. Results of the analyses for quarterly or triannual samples are listed in table 15 (at the back of this report). Results of the analyses for the seepage run samples are listed in table 16 (at the back of this report).

Semiquantitative mineralogical analyses of bed sediment were done using $\mathrm{X}$-ray diffraction techniques by the U.S. Geological Survey, geochemistry laboratory. Samples were sieved and the bulk samples (less than 180 micrometers) were analyzed. Results for the quarterly or triannual samples are shown in table 17 (at the back of this report) and the results for the seepage run samples are listed in table 18 (at the back of this report).

Heavy mineral concentrates were obtained from the bed sediment. The bulk sample was passed through a modified Frantz Isodynamic Magnetic Separator ${ }^{1}$ to produce three separate fractions based on their magnetic properties. The mineralogy for all three fractions was determined by optical techniques by the U.S. Geological Survey geochemistry laboratory. The C-1 fraction contains the highly magnetic minerals. Magnetite was the only mineral detected in this fraction. The $\mathrm{C}-2$ fraction is the moderately to weakly magnetic, mostly non-ore minerals. The C-3 fraction contains the non-magnetic ore and non-ore minerals. The weight percentages of each of the fractions from the heavy mineral concentrates for the quarterly or triannual samples are given in table 19 (at the back of this report). Mineralogy of the C-2 fraction for quarterly or triannual samples is listed in table 20 (at the back of this report) and for the seepage run sample in table 21 (at the back of this report). Results of emission spectrograph analyses of the C-3 fraction for the quarterly or triannual samples are listed in table 22 (at the back of this report) and for the samples from the seepage run sites in table 23 (at the back of this report). The mineralogy of the C-3 fraction for quarterly or triannual samples is listed in table 24 (at the back of this report) and for the seepage run samples in table 25 (at the back of this report). Elemental composition of carbonate minerals in the C-3 fraction was determined by laser spectrometry.

${ }^{1}$ Use of trade names in this report is for identification purposes only and does not constitute endorsement by the U.S. Geological Survey. 
To determine solid-phase association of trace elements, selected bed sediment samples also were analyzed by scanning electron microscope using energy dispersive and wavelength dispersive $X$-ray at the U.S. Bureau of Mines, Rolla, Missouri. Polished mounts were analyzed for the fine and the coarse fractions. Results of these analyses are listed in table 26 (at the back of this report).

\section{Summary}

The combined gravel- and sand-size component (larger than 0.062 millimeter) generally was the dominant fraction in bed sediment. Total element contents in both the fine and coarse fractions for lead and zinc in bed sediment increased downstream from site 1 on the Big River and downstream from site 7 on the Flat River. Lead and zinc contents decreased on the Big River from site 6 to site 12.

The largest lead content detected in the quarterly or triannual samples was at seepage site $8(38,000$ micrograms per gram). The largest zinc contents were at seepage sites 8 and $9(78,000$ and more than 100,000 micrograms per gram).

Quartz was the predominant mineral in the bulk sample (less than 180 micrometers) at sites 1, 7, and 12 and carbonate minerals were predominant at all other sites. For the heavy mineral concentrates, the C2 fraction generally was the largest by weight percent. This fraction predominately was carbonate and oxidized minerals, with galena and pyrite as the sulfides most often present. Some C- 3 fractions were as much as 80 percent sulfide minerals, but generally were less than 50 percent sulfide minerals. Galena, pyrite, and sphalerite were the most commonly detected sulfide minerals. Most trace elements generally were either in the oxide or sulfide phase in bed sediment; however, at seepage sites 8 and 9 zinc was associated predominantly with the carbonate phase. 


\section{REFERENCES}

Association of Missouri Geologists, 1969, Major geologic features of lead and barite districts of southeast Missouri-16th annual field trip guide: Viburnum, Mo., $24 \mathrm{p}$.

Buchanan, T.J., and Somers, W.P., 1969, Discharge measurements at gaging stations: U.S. Geological Survey Techniques of Water-Resources Investigations, Book 5, Chapter A3, 40 p.

Edwards, T.K., and Glysson, G.D., 1988, Field methods for measurement of fluvial sediment: U.S. Geological Survey Open-File Report 86-531, 118 p.

Guy, H.P., 1969, Laboratory theory and methods for sediment analysis: U.S. Geological Survey Techniques of Water-Resources Investigations, Book 5, Chapter C1, $58 \mathrm{p}$.

Guy, H.P., and Norman, V.W., 1970, Field methods for measurement of fluvial sediment: U.S. Geological Survey Techniques of Water-Resources Investigations, Book 3, Chapter C2, 59 p.

Fenneman, N.M., 1938, Physiography of eastern United States: New York, McGraw Hill, 714 p.

Fishman, M.J., and Friedman, L.C., eds., 1989, Methods for determination of inorganic substances in water and fluvial sediments: U.S. Geological Survey Techniques of Water-Resources Investigations, Book 5, Chapter A1, 545 p.

Kania, D.M., and Nash, Tom, 1986, Impact of lead on migratory birds in Missouri: Columbia, Mo., U.S. Fish and Wildlife Service, $41 \mathrm{p}$.

Kramer, R.L., 1976, Effects of a century old Missouri lead mining operation upon the water quality, sediments and biota of Flat River Creek: University of Missouri-Rolla, unpublished M.S. thesis, $111 \mathrm{p}$.

Smith, B.J., 1988, Assessment of water quality in non-coal mining areas of Missouri: U.S. Geological Survey Water-Resources Investigations Report 87-4286, $50 \mathrm{p}$.

U.S. Geological Survey, and Missouri Division of Geology and Land Survey, 1967, Mineral and water resources of Missouri: U.S. 90th Congress, 1st Session, Senate Document 19, 399 p.; also Missouri Division of Geology and Land Survey, v. XLIII. 2nd ser., 399 p.

Waite, L.A., Davis, J.V., Reed, H.L., Hatten, D.O., and Perkins, T.J., 1989, Water resources data, Missouri, Water year 1988: U.S. Geological Survey Water-Data Report MO-88-1, 289 p. (published annually).

1990, Water resources data, Missouri, Water year 1989: U.S. Geological Survey Water-Data Report MO-89-1, 353 p. (published annually).

pirye $19^{17}$ follows 
Table 1.--Water-quality and sediment sampling sites

[DDMMSS, degrees minutes seconds; --, no downstream order number available]

\begin{tabular}{rlccc}
\hline & & \multicolumn{3}{c}{ Site identification number } \\
\cline { 3 - 5 } $\begin{array}{l}\text { Site no. } \\
\text { (fig. 2) }\end{array}$ & Name & $\begin{array}{c}\text { Downstream order } \\
\text { number }\end{array}$ & $\begin{array}{c}\text { Latitude } \\
\text { DDMMSS }\end{array}$ & $\begin{array}{c}\text { Longitude } \\
\text { DDMMSS }\end{array}$ \\
\hline 1 & Big River at Irondale & 07017200 & 374948 & 0904127 \\
2 & Eaton Creek at Leadwood & - & 375200 & 0903554 \\
3 & Big River at Bonehole & - & 375232 & 0903258 \\
4 & Drill hole at Bonehole & - & 375231 & 0903259 \\
5 & Tunnel seep at Desloge & -- & 375232 & 0903255 \\
6 & Big River below Desloge & 07017260 & 375322 & 0903107 \\
7 & Flat River at Derby & 07017270 & 374936 & 0903222 \\
8 & Elvins seep at pile & -- & 375032 & 0903158 \\
9 & Elvins seep at Highway 32 & -- & 375028 & 0903146 \\
10 & National seep at railroad & -- & 375135 & 0903031 \\
11 & Flat River at National tailings pile & 07017350 & 375201 & 0903019 \\
12 & Big River near Richwoods & 07018100 & 380934 & 0904222 \\
& & & & \\
\hline
\end{tabular}


Table 2.--Daily mean discharge for the Big River below Desloge

[Site location-site 6, fig. 2; values, in cubic feet per second; --, no data available]

\begin{tabular}{|c|c|c|c|c|c|c|c|c|c|c|}
\hline \multirow[b]{2}{*}{ DAY } & \multicolumn{9}{|c|}{1988} & \multirow[b]{2}{*}{ Dec. } \\
\hline & Mar. & Apr. & May & June & July & Aug. & Sept. & Oct. & Nov. & \\
\hline 1 & -- & 675 & 104 & 51 & 82 & 36 & 23 & 85 & 40 & 260 \\
\hline 2 & -- & 667 & 100 & 48 & 67 & 35 & 25 & 446 & 39 & 231 \\
\hline 3 & -- & 609 & 112 & 45 & 69 & 33 & 32 & 210 & 38 & 203 \\
\hline 4 & -- & 466 & 1,080 & 45 & 72 & 32 & 33 & 135 & 178 & 176 \\
\hline 5 & -- & 403 & 382 & 43 & 60 & 31 & 34 & 101 & 308 & 153 \\
\hline 6 & -- & 428 & 237 & 42 & 52 & 30 & 31 & 83 & 158 & 139 \\
\hline 7 & -- & 412 & 186 & 40 & 47 & 29 & 28 & 72 & 110 & 126 \\
\hline 8 & - & 353 & 159 & 42 & 44 & 28 & 26 & 65 & 87 & 115 \\
\hline 9 & -- & 318 & 152 & 55 & 41 & 27 & 25 & 60 & 74 & 105 \\
\hline 10 & -- & 290 & 140 & 59 & 39 & 26 & 24 & 56 & 70 & 98 \\
\hline 11 & -- & 265 & 121 & 48 & 39 & 25 & 24 & 52 & 69 & 92 \\
\hline 12 & -- & 245 & 110 & 43 & 77 & 25 & 25 & 48 & 84 & 87 \\
\hline 13 & -- & 224 & 103 & 41 & 89 & 25 & 26 & 44 & 289 & 82 \\
\hline 14 & - & 207 & 97 & 38 & 63 & 25 & 26 & 42 & 216 & 81 \\
\hline 15 & -- & 190 & 90 & 35 & 51 & 24 & 24 & 40 & 158 & 78 \\
\hline 16 & -- & 173 & 84 & 361 & 44 & 24 & 22 & 40 & 263 & 73 \\
\hline 17 & -- & 157 & 76 & 203 & 39 & 24 & 22 & 41 & 258 & 70 \\
\hline 18 & - & 171 & 73 & 96 & 37 & 23 & 471 & 43 & 179 & 67 \\
\hline 19 & -- & 176 & 70 & 65 & 36 & 31 & 841 & 44 & 1,760 & 66 \\
\hline 20 & -- & 156 & 67 & 53 & 90 & 32 & 187 & 45 & 3,970 & 66 \\
\hline 21 & -. & 142 & 65 & 47 & 215 & 25 & 111 & 44 & 1,680 & 66 \\
\hline 22 & -- & 139 & 67 & 43 & 110 & 26 & 75 & 42 & 681 & 66 \\
\hline 23 & 172 & 137 & 88 & 40 & 73 & 28 & 63 & 44 & 462 & 254 \\
\hline 24 & 161 & 133 & 108 & 39 & 57 & 27 & 62 & 45 & 368 & 291 \\
\hline 25 & 639 & 129 & 95 & 41 & 49 & 26 & 81 & 45 & 312 & 224 \\
\hline 26 & 489 & 131 & 80 & 43 & 44 & 26 & 96 & 43 & 912 & 184 \\
\hline 27 & 332 & 125 & 70 & 39 & 41 & 24 & 70 & 42 & 740 & 273 \\
\hline 28 & 262 & 118 & 65 & 36 & 39 & 24 & 57 & 42 & 600 & 1,840 \\
\hline 29 & 2,500 & 114 & 61 & 44 & 37 & 24 & 51 & 43 & 440 & 679 \\
\hline 30 & 4,330 & 109 & 58 & 85 & 36 & 25 & 47 & 42 & 350 & 414 \\
\hline 31 & 1,060 & -- & 53 & -- & 37 & 24 & -- & 41 & -- & 327 \\
\hline TOTAL & -- & 7,862 & 4,353 & 1,910 & 1,876 & 844 & 2,662 & 2,225 & 14,893 & 6,986 \\
\hline MEAN & -- & 262 & 140 & 63.7 & 60.5 & 27.2 & 88.7 & 71.8 & 496 & 225 \\
\hline MAXIMUM & -- & 675 & 1,080 & 361 & 215 & 36 & 841 & 446 & 3,970 & 1,840 \\
\hline MINIMUM & -- & 109 & 53 & 35 & 36 & 23 & 22 & 40 & 38 & 66 \\
\hline
\end{tabular}


Table 2.--Daily mean discharge for the Big River below Desloge--Continued

\begin{tabular}{|c|c|c|c|c|c|c|c|c|c|}
\hline \multirow[b]{2}{*}{ DAY } & \multicolumn{8}{|c|}{1989} & \multirow[b]{2}{*}{ Sept. } \\
\hline & Jan. & Feb. & Mar. & Apr. & May & June & July & Aug. & \\
\hline 1 & 296 & 152 & 189 & 874 & 198 & 82 & 83 & 67 & 37 \\
\hline 2 & 329 & 228 & 183 & 618 & 172 & 80 & 80 & 63 & 37 \\
\hline 3 & 354 & 1,190 & 183 & 749 & 156 & 80 & 80 & 58 & 36 \\
\hline 4 & 370 & 496 & 187 & 1,100 & 146 & 84 & 77 & 54 & 36 \\
\hline 5 & 588 & 352 & 319 & 630 & 140 & 186 & 71 & 51 & 35 \\
\hline 6 & 1,370 & 299 & 313 & 469 & 130 & 238 & 67 & 47 & 34 \\
\hline 7 & 649 & 250 & 268 & 460 & 120 & 159 & 62 & 43 & 34 \\
\hline 8 & 433 & 224 & 248 & 476 & 121 & 124 & 58 & 41 & 32 \\
\hline 9 & 328 & 190 & 298 & 451 & 179 & 105 & 54 & 38 & 32 \\
\hline 10 & 279 & 176 & 784 & 369 & 188 & 94 & 50 & 37 & 33 \\
\hline 11 & 245 & 160 & 1,720 & 327 & 154 & 87 & 47 & 37 & 34 \\
\hline 12 & 224 & 146 & 934 & 300 & 136 & 95 & 45 & 36 & 35 \\
\hline 13 & 190 & 1,640 & 543 & 276 & 125 & 329 & 45 & 35 & 38 \\
\hline 14 & 165 & 4,560 & 418 & 256 & 118 & 952 & 47 & 34 & 69 \\
\hline 15 & 158 & 1,630 & 345 & 249 & 111 & 383 & 46 & 34 & 92 \\
\hline 16 & 140 & 1,500 & 286 & 239 & 105 & 267 & 43 & 38 & 75 \\
\hline 17 & 126 & 724 & 252 & 220 & 99 & 199 & 43 & 39 & 60 \\
\hline 18 & 117 & 517 & 226 & 206 & 96 & 816 & 46 & 47 & 52 \\
\hline 19 & 107 & 423 & 200 & 195 & 93 & 1,030 & 52 & 44 & 46 \\
\hline 20 & 98 & 377 & 452 & 183 & 89 & 356 & 68 & 41 & 42 \\
\hline 21 & 91 & 400 & 1,020 & 175 & 84 & 240 & 102 & 42 & 40 \\
\hline 22 & 85 & 339 & 530 & 167 & 99 & 186 & 146 & 45 & 39 \\
\hline 23 & 82 & 278 & 382 & 159 & 192 & 155 & 123 & 54 & 37 \\
\hline 24 & 79 & 240 & 319 & 152 & 179 & 134 & 171 & 51 & 35 \\
\hline 25 & 79 & 225 & 278 & 145 & 143 & 119 & 203 & 44 & 34 \\
\hline 26 & 158 & 216 & 247 & 138 & 277 & 105 & 235 & 42 & 34 \\
\hline 27 & 292 & 214 & 222 & 131 & 174 & 98 & 190 & 45 & 34 \\
\hline 28 & 217 & 200 & 219 & 425 & 132 & 118 & 124 & 47 & 34 \\
\hline 29 & 199 & -- & 298 & 313 & 114 & 110 & 97 & 42 & 34 \\
\hline 30 & 189 & -- & 893 & 247 & 104 & 92 & 80 & 38 & 34 \\
\hline 31 & 169 & -- & 2,470 & -- & 91 & -- & 73 & 37 & -- \\
\hline TOTAL & 8,206 & 17,346 & 15,226 & 10,699 & 4,265 & 7,103 & 2,708 & 1,371 & 1,244 \\
\hline MEAN & 265 & 619 & 491 & 357 & 138 & 237 & 87.4 & 44.2 & 41.5 \\
\hline MAXIMUM & 1,370 & 4,560 & 2,470 & 1,100 & 277 & 1,030 & 235 & 67 & 92 \\
\hline MINIMUM & 79 & 146 & 183 & 131 & 84 & 80 & 43 & 34 & 32 \\
\hline
\end{tabular}


Table 3.--Daily mean discharge for the Flat River at National tailings pile

[Site location-site 11, fig. 2; values, in cubic feet per second; --, no data available]

\begin{tabular}{|c|c|c|c|c|c|c|c|c|c|c|}
\hline \multirow[b]{2}{*}{ DAY } & \multicolumn{9}{|c|}{1988} & \multirow[b]{2}{*}{ Nov. } \\
\hline & Feb. & Mar. & Apr. & May & June & July & Aug. & Sept. & Oct. & \\
\hline 1 & -- & 13 & 76 & 6.9 & 4.0 & 3.6 & 3.0 & 2.7 & 8.4 & 3.3 \\
\hline 2 & -- & 14 & 99 & 6.8 & 3.8 & 3.3 & 2.8 & 5.6 & 7.7 & 3.2 \\
\hline 3 & -- & 227 & 69 & 11 & 4.1 & 3.0 & 2.6 & 6.0 & 3.9 & 3.4 \\
\hline 4 & -- & 127 & 52 & 116 & 3.1 & 3.1 & 3.1 & 3.4 & 3.2 & 57 \\
\hline 5 & -- & 52 & 40 & 30 & 3.1 & 2.8 & 2.3 & 2.5 & 2.8 & 15 \\
\hline 6 & -- & 47 & 60 & 19 & 3.1 & 2.7 & 2.4 & 2.2 & 2.6 & 8.0 \\
\hline 7 & -- & 36 & 44 & 14 & 2.9 & 2.6 & 2.4 & 2.2 & 2.6 & 6.6 \\
\hline 8 & -- & 32 & 35 & 12 & 4.9 & 2.6 & 2.3 & 2.2 & 2.4 & 5.9 \\
\hline 9 & -- & 33 & 30 & 12 & 4.3 & 2.4 & 2.4 & 2.3 & 2.5 & 5.6 \\
\hline 10 & -- & 33 & 25 & 9.5 & 3.2 & 2.3 & 2.5 & 2.3 & 2.3 & 9.0 \\
\hline 11 & -- & 39 & 22 & 8.4 & 2.9 & 2.3 & 2.6 & 2.4 & 2.0 & 7.3 \\
\hline 12 & -- & 174 & 19 & 7.9 & 2.9 & 5.1 & 2.7 & 2.4 & 1.9 & 18 \\
\hline 13 & -- & 99 & 17 & 7.3 & 3.3 & 3.3 & 2.8 & 2.3 & 1.9 & 16 \\
\hline 14 & -- & 109 & 15 & 6.9 & 2.7 & 3.1 & 2.6 & -- & 2.0 & 11 \\
\hline 15 & -- & 92 & 14 & 6.9 & 2.8 & 3.0 & 2.6 & -- & 2.0 & 13 \\
\hline 16 & 35 & 64 & 12 & 5.9 & 3.8 & 3.3 & 2.8 & - & 2.4 & 83 \\
\hline 17 & 35 & 58 & 12 & 6.0 & 3.5 & 3.5 & 2.8 & -- & 2.6 & 27 \\
\hline 18 & 35 & 58 & 19 & 5.3 & 3.1 & 3.7 & 2.9 & 878 & 3.3 & 19 \\
\hline 19 & -- & 55 & 17 & 5.5 & 2.8 & 4.2 & 3.1 & 23 & & \\
\hline 20 & -- & 41 & 14 & 4.9 & 3.3 & 12 & 2.4 & 11 & & \\
\hline 21 & -- & 35 & 13 & 4.7 & 2.6 & 4.0 & 2.4 & 6.8 & 2.6 & 82 \\
\hline 22 & -- & 39 & 12 & 5.1 & 2.7 & 3.3 & 2.3 & 5.3 & 2.4 & 38 \\
\hline 23 & 26 & 38 & 10 & 5.5 & 2.7 & 3.8 & 2.8 & 5.6 & 3.5 & 25 \\
\hline 24 & 27 & 39 & 9.1 & 7.6 & 2.8 & 4.4 & 2.4 & 5.5 & 2.6 & 19 \\
\hline 25 & 23 & 185 & 8.7 & 5.3 & 2.9 & 5.0 & 2.5 & 5.0 & 2.5 & 16 \\
\hline 26 & 19 & 81 & 9.8 & 4.8 & 3.1 & 4.8 & 2.7 & 3.6 & 2.6 & 98 \\
\hline 27 & 19 & 55 & 9.0 & 4.6 & 3.0 & 4.4 & 2.6 & 2.7 & 4.1 & 90 \\
\hline 28 & 17 & 40 & 7.9 & 4.3 & 3.2 & 4.1 & 2.6 & 2.5 & 3.4 & 38 \\
\hline 29 & 13 & 615 & 7.8 & 4.6 & 5.5 & 3.7 & 2.6 & 2.3 & 3.4 & 25 \\
\hline 30 & -- & 248 & 7.3 & 4.1 & 4.4 & 3.5 & 2.6 & 2.2 & 2.9 & -- \\
\hline 31 & - & 113 & - & 4.1 & -- & 3.3 & 2.8 & - & 3.1 & - \\
\hline TOTAL & - & 2,891 & 786 & 357 & 100 & 116 & 81.4 & -- & 95.8 & - \\
\hline MEAN & -- & 93.3 & 26.2 & 11.5 & 3.35 & 3.75 & 2.63 & -- & 3.09 & -- \\
\hline MAXIMUM & -- & 615 & 99 & 116 & 5.5 & 12 & 3.1 & -- & 8.4 & -- \\
\hline MINIMUM & -- & 13 & 7.3 & 4.1 & 2.6 & 2.3 & 2.3 & -- & 1.9 & -- \\
\hline
\end{tabular}


Table 3.--Daily mean discharge for the Flat River at National tailings pile--Continued

\begin{tabular}{|c|c|c|c|c|c|c|c|c|c|c|}
\hline \multirow[b]{2}{*}{ DAY } & \multirow{2}{*}{$\frac{1988}{\text { Dec. }}$} & \multicolumn{9}{|c|}{1989} \\
\hline & & Jan. & Feb. & Mar. & Apr. & May & June & July & Aug. & Sept. \\
\hline 1 & -. & -- & 19 & 26 & 82 & 8.9 & 3.7 & 13 & 11 & 3.7 \\
\hline 2 & -- & -- & 94 & 24 & 69 & 8.1 & 3.4 & 14 & 9.9 & 3.4 \\
\hline 3 & -- & - & 146 & 24 & 86 & 7.8 & 3.2 & 11 & 8.9 & 3.2 \\
\hline 4 & -- & 39 & 55 & 24 & 87 & 7.8 & 4.9 & 9.9 & 8.0 & 3.1 \\
\hline 5 & -- & 95 & 36 & 48 & 51 & 7.4 & 25 & 8.9 & 7.0 & 3.1 \\
\hline 6 & -- & 114 & 26 & 31 & 43 & 6.7 & 9.0 & 9.2 & 6.2 & 2.9 \\
\hline 7 & -- & 66 & 21 & 26 & 45 & 6.4 & 6.2 & 8.9 & 5.4 & 2.9 \\
\hline 8 & -- & 44 & 19 & 29 & 50 & 8.7 & 5.4 & 8.0 & 5.0 & 2.7 \\
\hline 9 & -- & 33 & 16 & 71 & 38 & 11 & 4.9 & 7.2 & 5.0 & 2.9 \\
\hline 10 & -- & 29 & 16 & 133 & 32 & 9.7 & 4.0 & 6.8 & 4.6 & 3.1 \\
\hline 11 & -- & 26 & 18 & 128 & 28 & 7.4 & 9.2 & 6.3 & 4.5 & 3.2 \\
\hline 12 & -- & 24 & 17 & 68 & 26 & 7.0 & 23 & 6.8 & 4.4 & 2.9 \\
\hline 13 & -- & 21 & 500 & 46 & 24 & 6.2 & 154 & 6.3 & 4.2 & 4.4 \\
\hline 14 & - & 20 & 278 & 35 & 23 & 5.8 & 108 & 5.7 & 4.2 & \\
\hline 15 & -- & 20 & 239 & 27 & 23 & 5.5 & 47 & 5.6 & 4.0 & 7.2 \\
\hline 16 & -- & 18 & 153 & 21 & 21 & 5.4 & 30 & 5.1 & 5.9 & 5.1 \\
\hline 17 & -- & 18 & 96 & 19 & 19 & 5.3 & 22 & 5.0 & 5.0 & 4.6 \\
\hline 18 & -- & 17 & 71 & 17 & 18 & 5.0 & 212 & 5.4 & 4.4 & 4.4 \\
\hline 19 & -- & 16 & 58 & 15 & 17 & 4.8 & 118 & 7.1 & 4.2 & 3.8 \\
\hline 20 & -- & 16 & 59 & 114 & 16 & 4.4 & 52 & 12 & 3.9 & 3.6 \\
\hline 21 & -- & 14 & 60 & 108 & 16 & 3.8 & 37 & 17 & 4.7 & 3.1 \\
\hline 22 & -- & 14 & 46 & 53 & 14 & 14 & 30 & 11 & 6.3 & 3.0 \\
\hline 23 & -- & 14 & 35 & 37 & 14 & 14 & 25 & 42 & 5.0 & 2.8 \\
\hline 24 & -- & 14 & 28 & 29 & 13 & 7.4 & 23 & 125 & 4.0 & 2.6 \\
\hline 25 & -- & 15 & 27 & 24 & 12 & 6.0 & 19 & 117 & 3.9 & 2.5 \\
\hline 26 & -- & 28 & 27 & 21 & 12 & 16 & 18 & 50 & 4.8 & 2.5 \\
\hline 27 & -- & 22 & 26 & 18 & 11 & 6.7 & 17 & 25 & 4.7 & 2.4 \\
\hline 28 & -. & 20 & 24 & 23 & 11 & 5.2 & 16 & 21 & 4.4 & 2.5 \\
\hline 29 & -- & 22 & -- & 66 & 10 & 5.0 & 15 & 63 & 3.7 & 2.5 \\
\hline 30 & -- & 21 & -- & 279 & 9.1 & 4.9 & 13 & 19 & 4.1 & 2.6 \\
\hline 31 & -- & 20 & -- & 218 & -- & 3.9 & -- & 14 & 3.9 & -- \\
\hline TOTAL & -- & -- & 2,210 & 1,802 & 920.1 & 226.2 & $1,057.9$ & 666.2 & 165.2 & 116.7 \\
\hline MEAN & -- & -- & 78.9 & 58.1 & 30.7 & 7.30 & 35.3 & 21.5 & 5.33 & 3.89 \\
\hline MAXIMUM & -- & -- & 500 & 279 & 87 & 16 & 212 & 125 & 11 & 20 \\
\hline MINIMUM & -- & -- & 16 & 15 & 9.1 & 3.8 & 3.2 & 5.0 & 3.7 & 2.4 \\
\hline
\end{tabular}




\section{TABLES 4 AND 5}

\section{ABBREVIATIONS AND REPORTING UNITS FOR CHEMICAL CONSTITUENTS AND NOTATIONS USED IN TABLES}

Q Instantaneous discharge, in cubic feet per second

SC Specific conductance, in microsiemens per centimeter at 25 degrees Celsius

$\mathrm{pH} \quad$ In standard units

WT Water temperature, in degrees Celsius

$\mathrm{H}$ Total hardness, in milligrams per liter as $\mathrm{CaCO}_{3}$

$\mathrm{NH}$ Noncarbonate hardness, in milligrams per liter as $\mathrm{CaCO}_{3}$

Ca Dissolved calcium, in milligrams per liter

$\mathrm{Mg}$ Dissolved magnesium, in milligrams per liter

$\mathrm{Na}$ Dissolved sodium, in milligrams per liter

$\mathrm{K}$ Dissolved potassium, in milligrams per liter

$\mathrm{HCO}_{3}$ Bicarbonate, in milligrams per liter

$\mathrm{CO}_{3}$ Carbonate, in milligrams per liter

Alk Total alkalinity, in milligrams per liter as $\mathrm{CaCO}_{3}$

$\mathrm{SO}_{4} \quad$ Dissolved sulfate, in milligrams per liter

$\mathrm{Cl}$ Dissolved chloride, in milligrams per liter

$\mathrm{SiO}_{2}$ Dissolved silica, in milligrams per liter

DS Dissolved solids, residue at 180 degrees Celsius, in milligrams per liter

DSS Dissolved solids, sum of constituents, in milligrams per liter

P Dissolved phosphorous, in milligrams per liter
$\mathrm{PO}_{4}$ Dissolved orthophosphate, in milligrams per liter

Al Dissolved aluminum, in micrograms per liter

Ba Dissolved barium, in micrograms per liter

$\mathrm{Be}$ Dissolved beryllium, in micrograms per liter

Cd Dissolved cadmium, in micrograms per liter

Cr Dissolved chromium, in micrograms per liter

Co Dissolved cobalt, in micrograms per liter

$\mathrm{Cu}$ Dissolved copper, in micrograms per liter

Fe Dissolved iron, in micrograms per liter

$\mathrm{Pb}$ Dissolved lead, in micrograms per liter

$\mathrm{Li}$ Dissolved lithium, in micrograms per liter

Mn Dissolved manganese, in micrograms per liter

Mo Dissolved molybdenum, in micrograms per liter

$\mathrm{Ni}$ Dissolved nickel, in micrograms per liter

Ag Dissolved silver, in micrograms per liter

Sr Dissolved strontium, in micrograms per liter

V Dissolved vanadium, in micrograms per liter

Zn Dissolved zinc, in micrograms per liter

SS Suspended sediment, in milligrams per liter

-- $\quad$ No data available

$<\quad$ Less than

E Estimated 


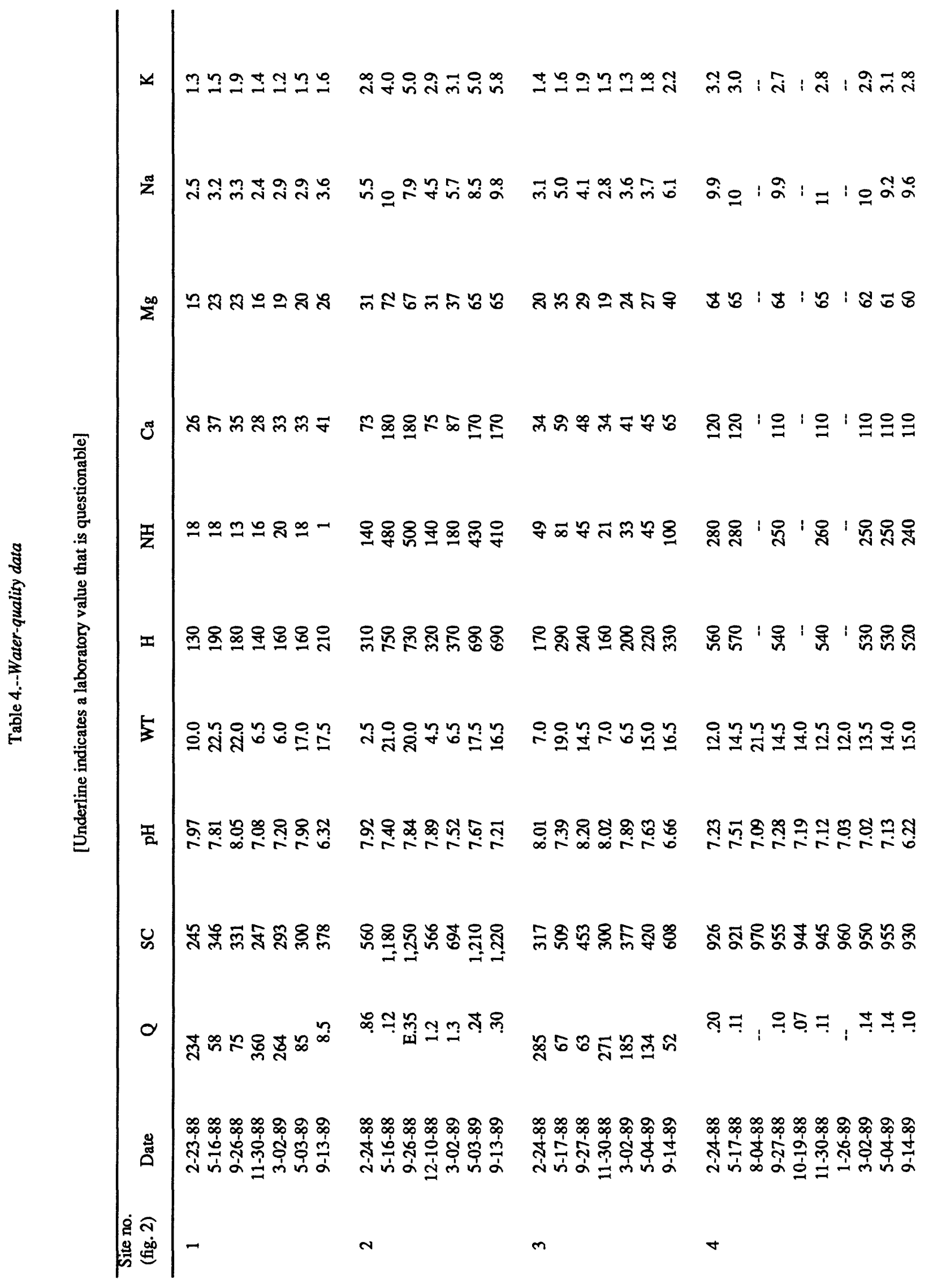




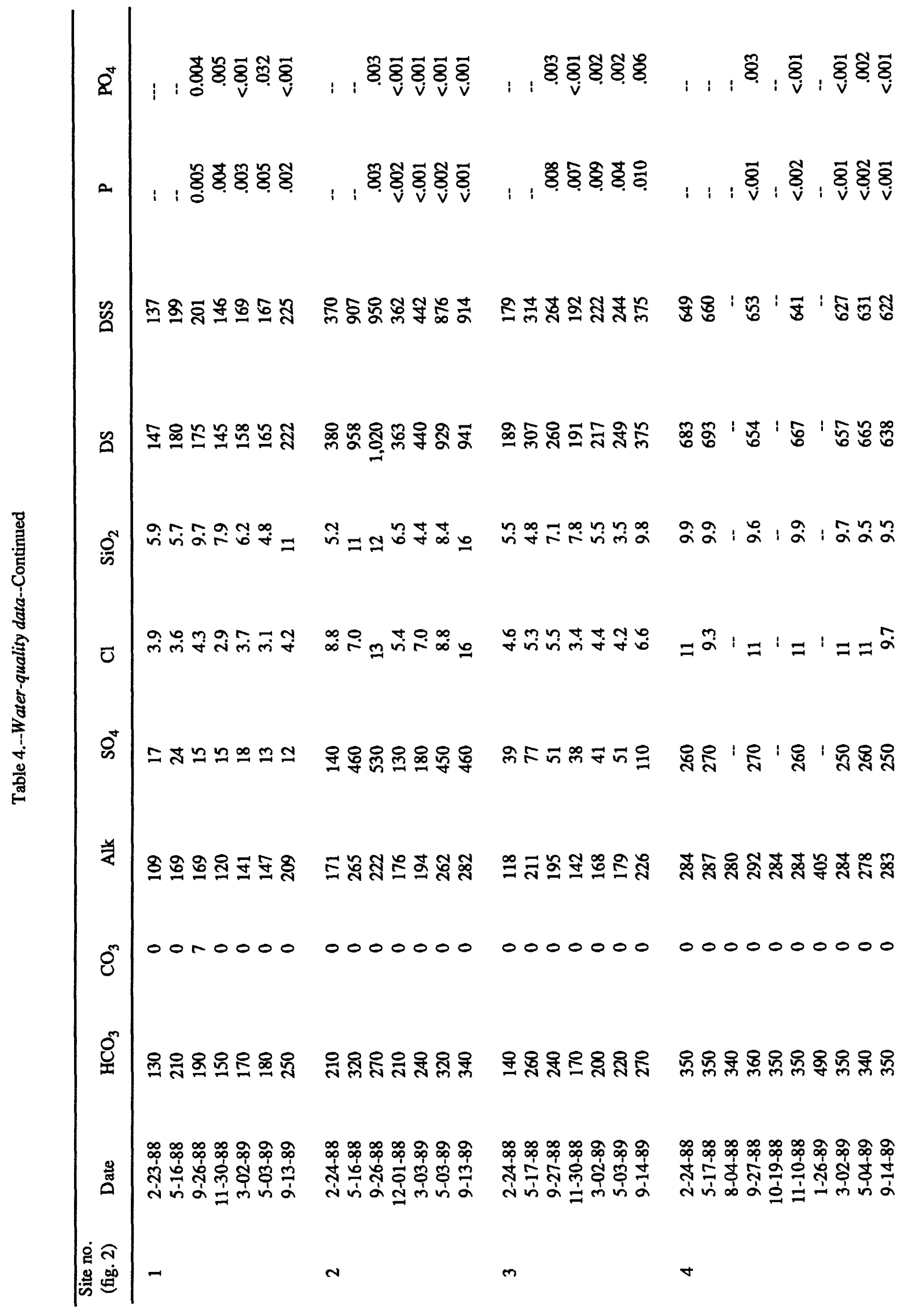




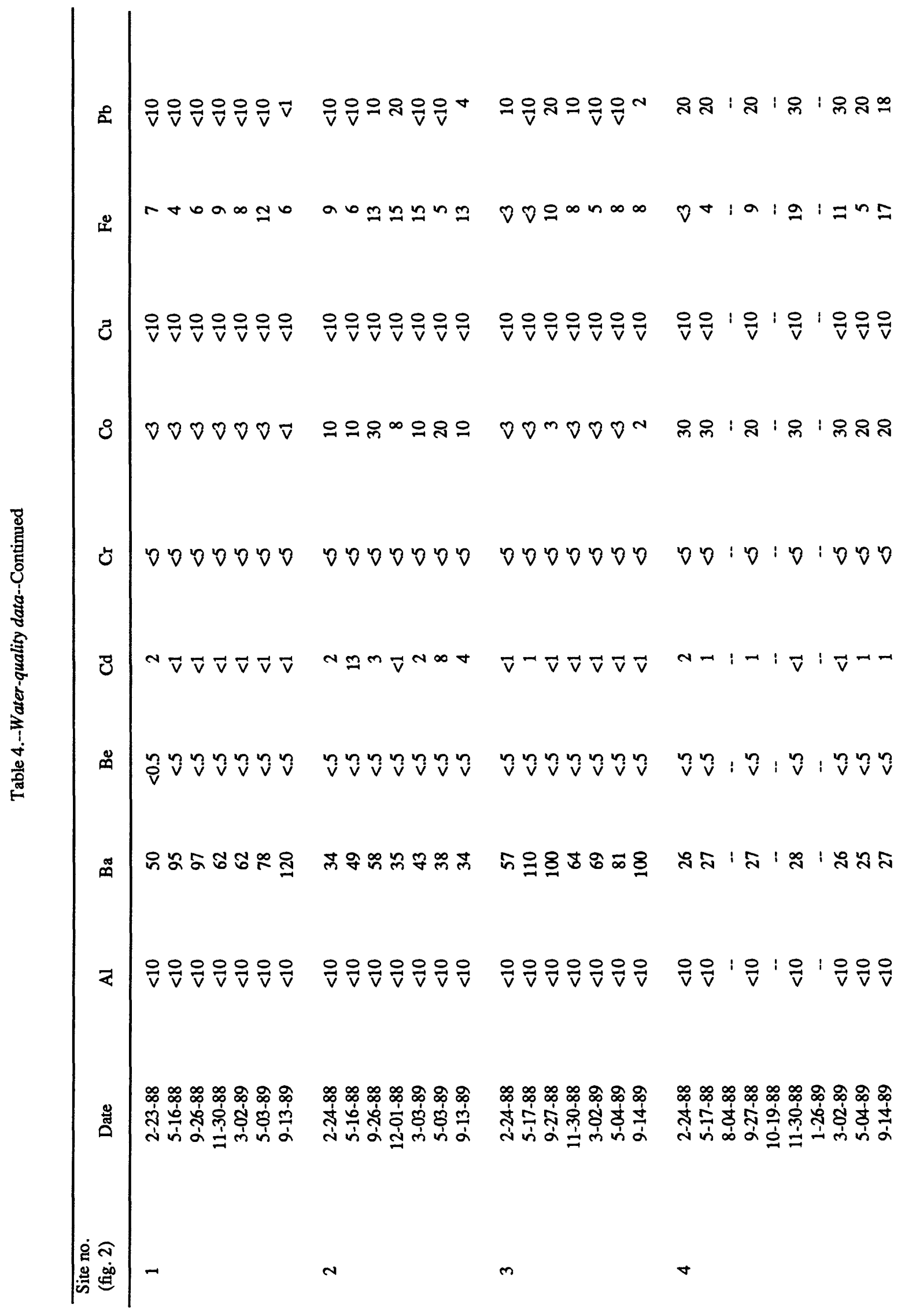




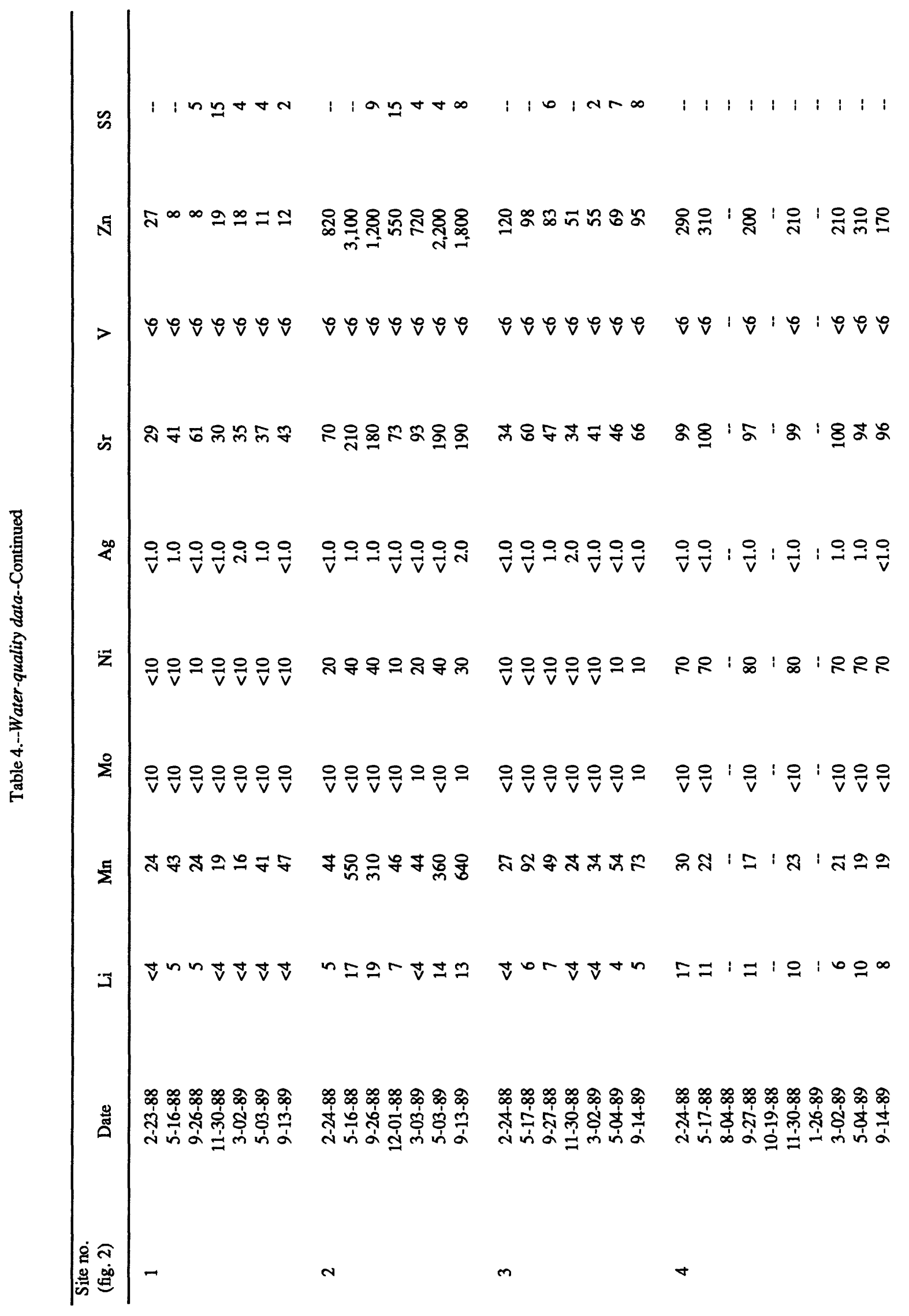




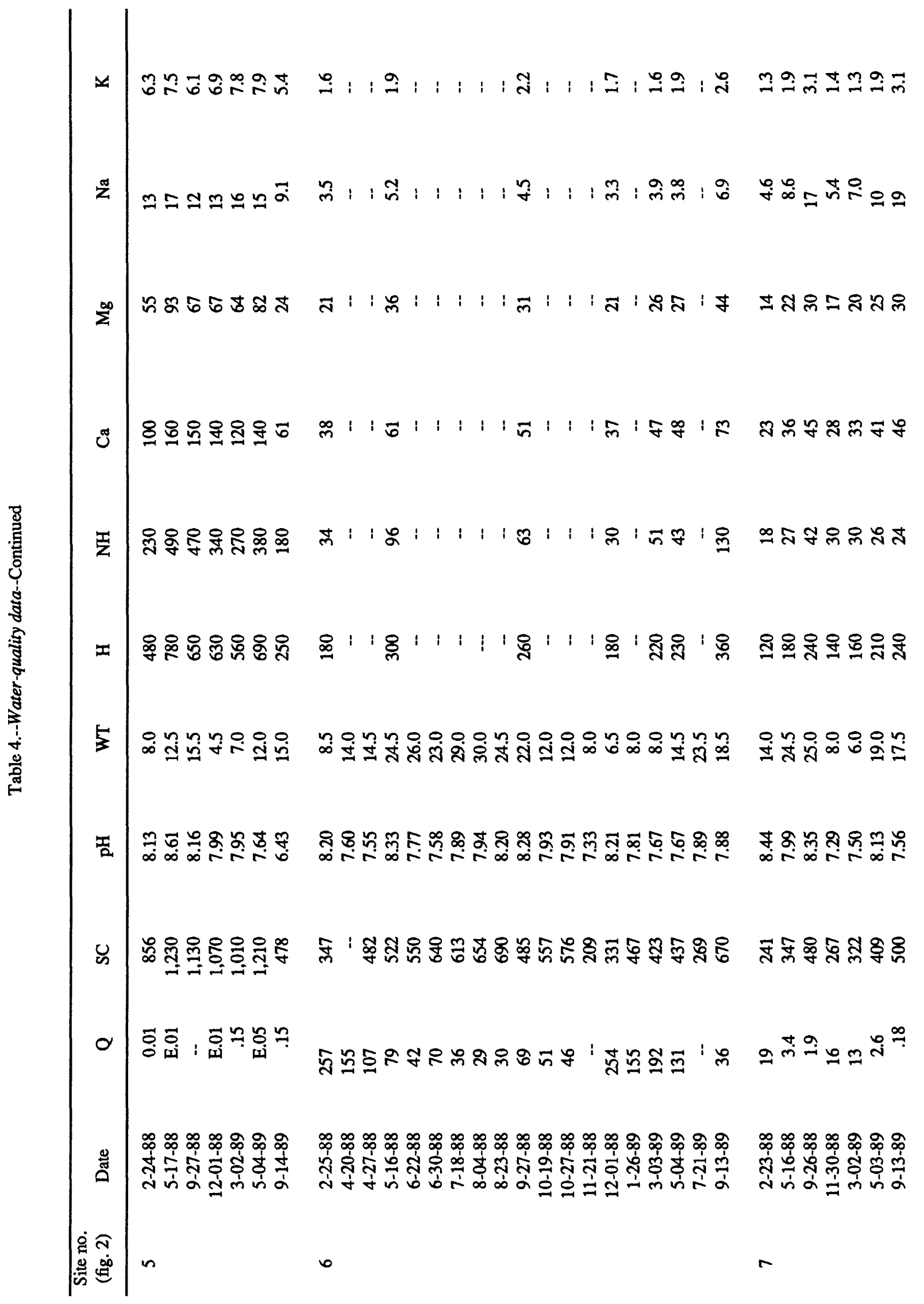




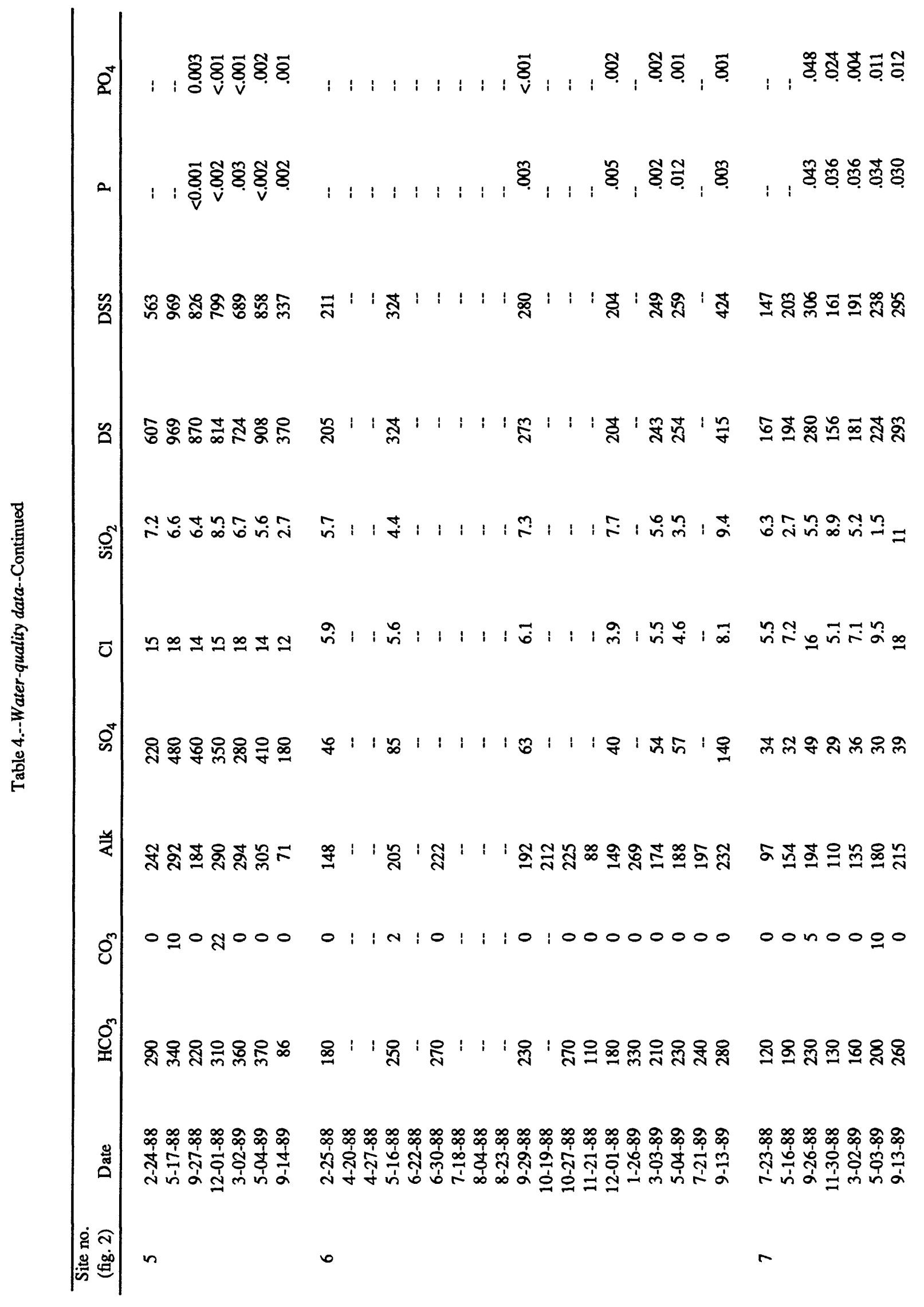




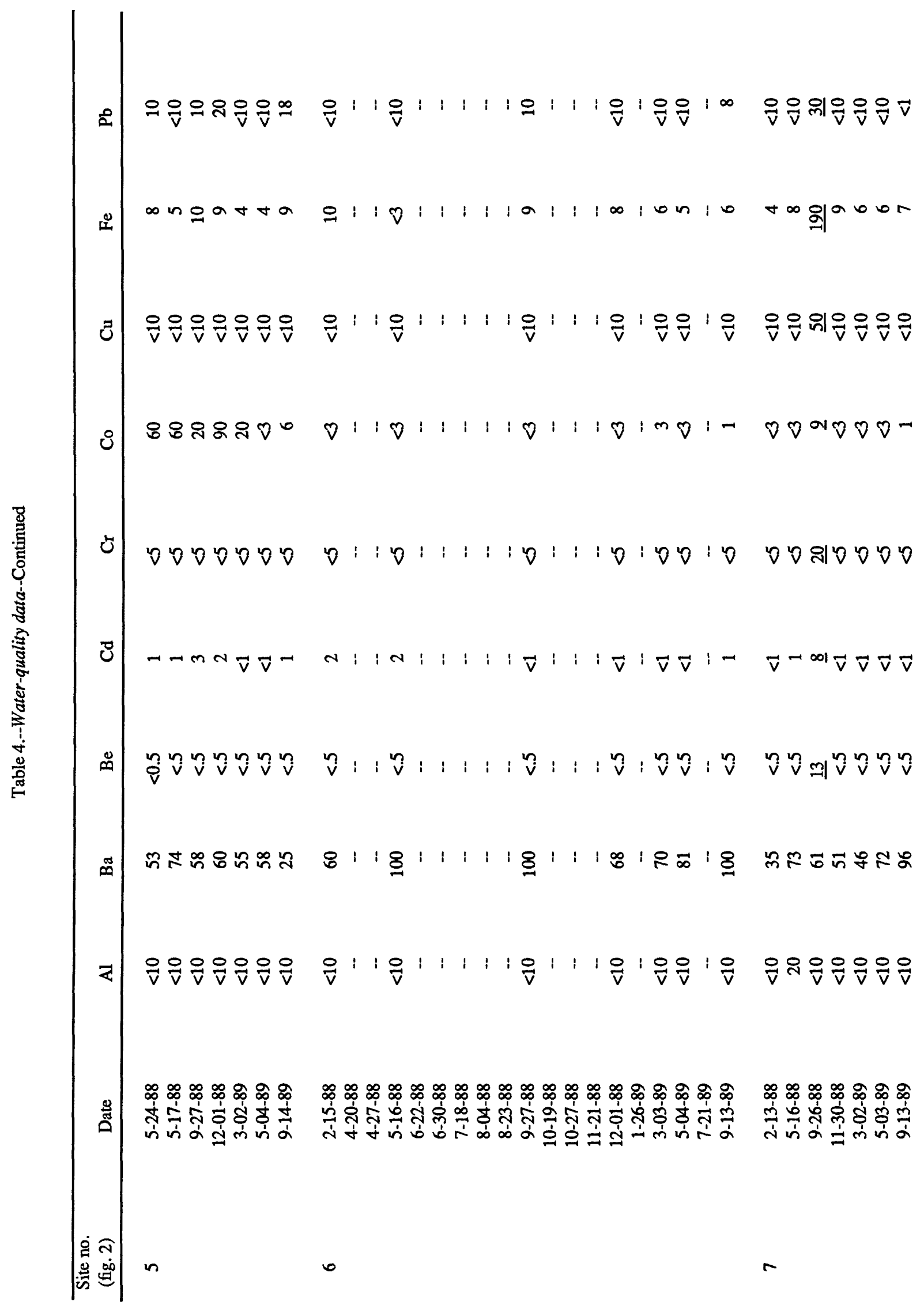




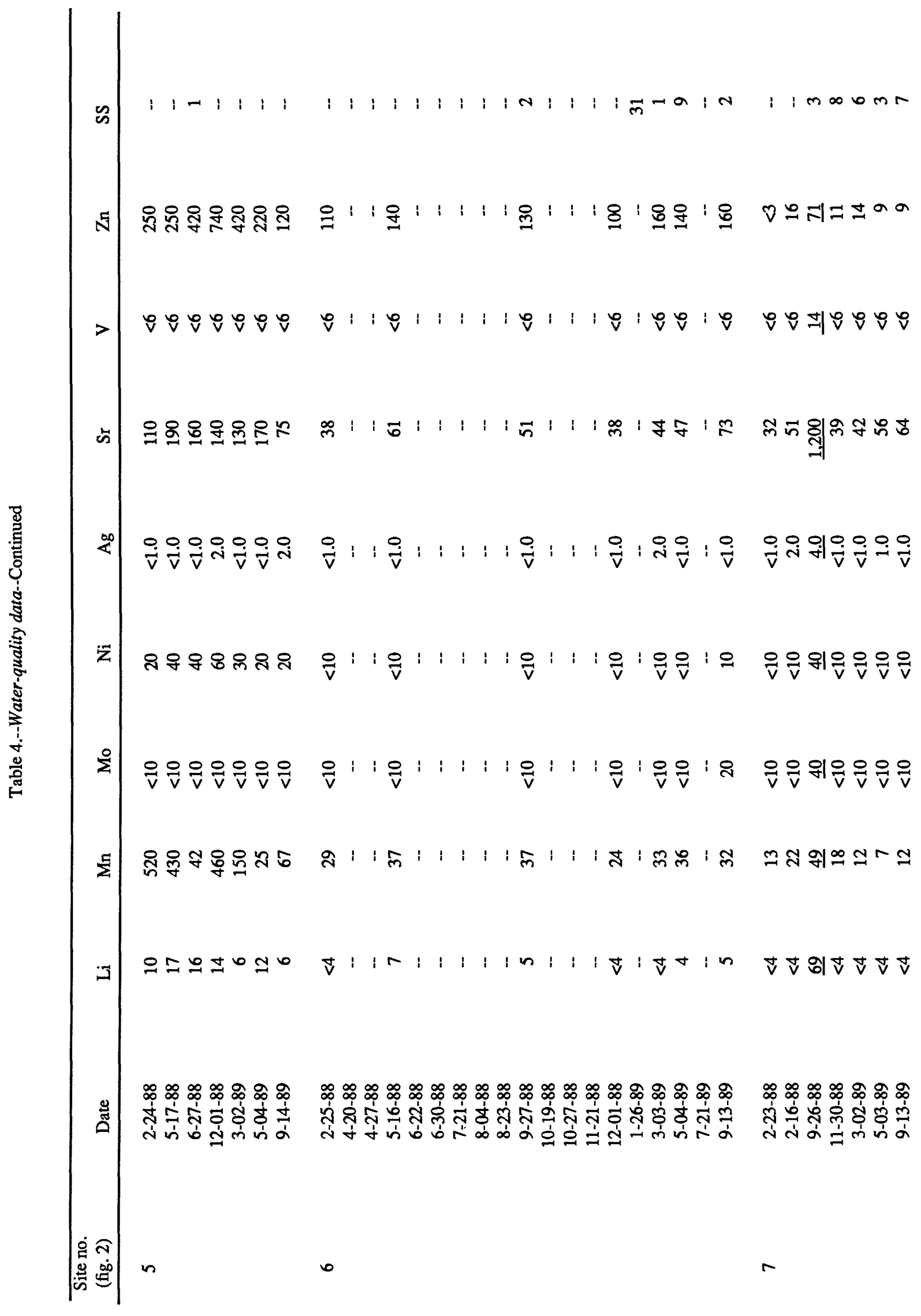




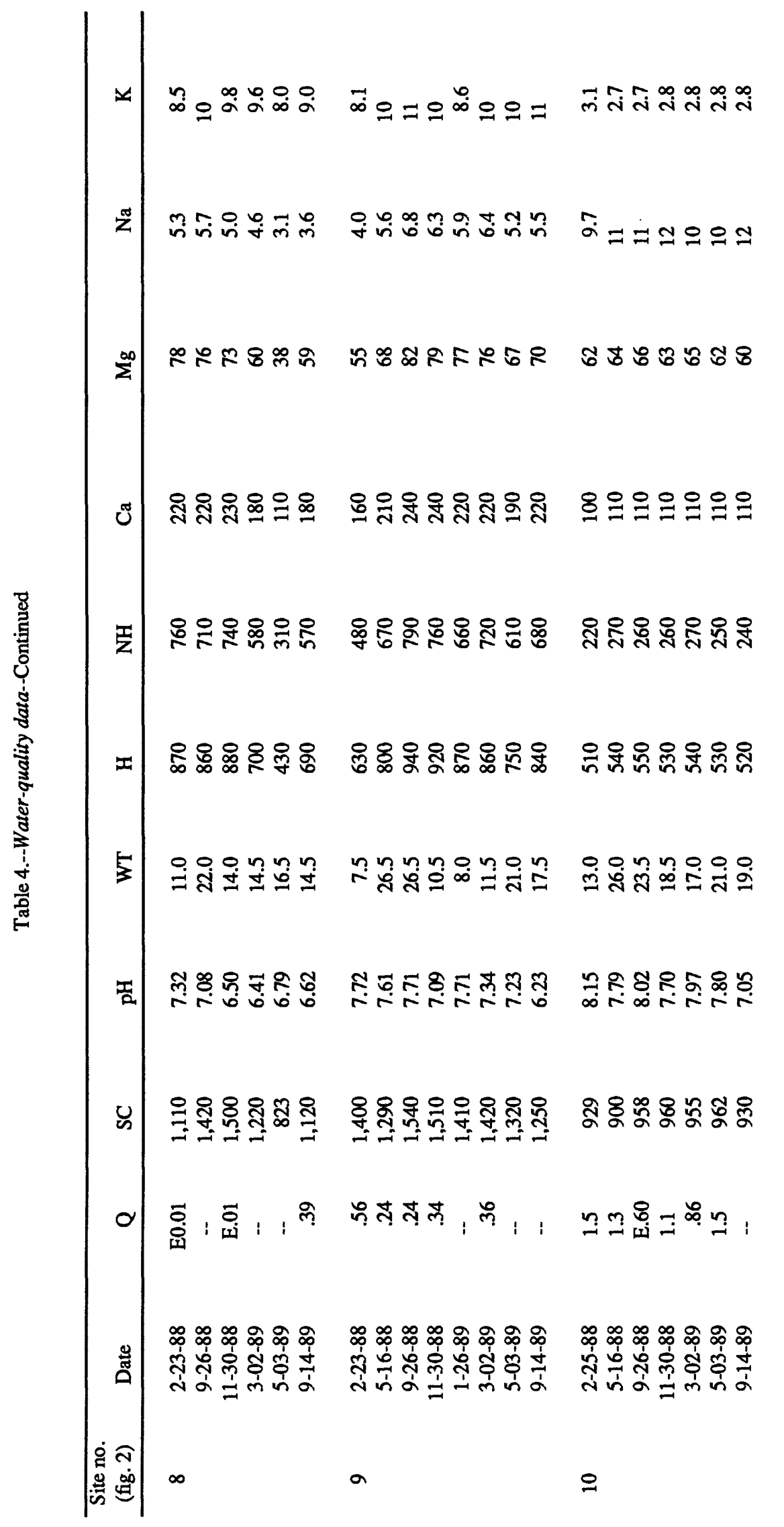




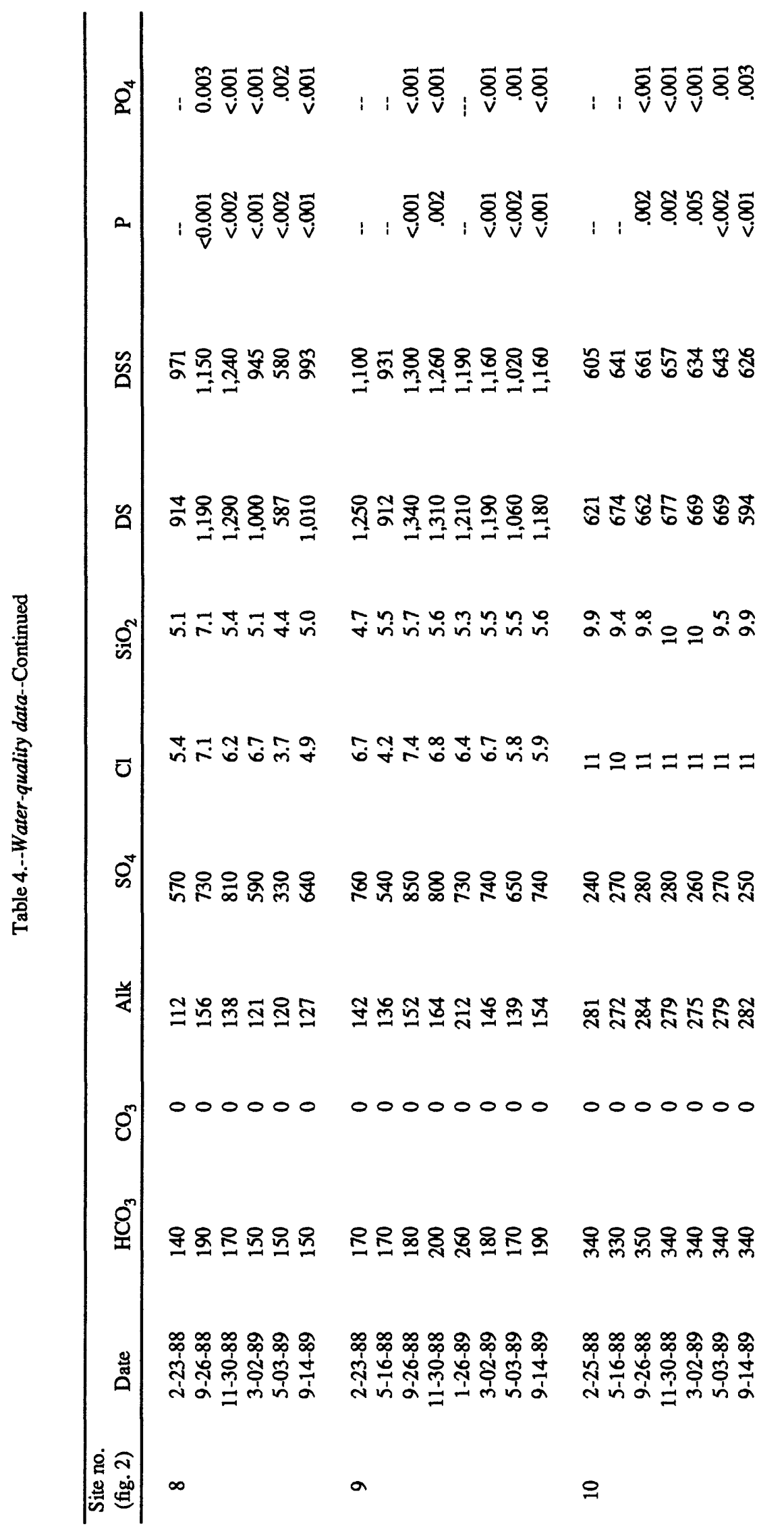




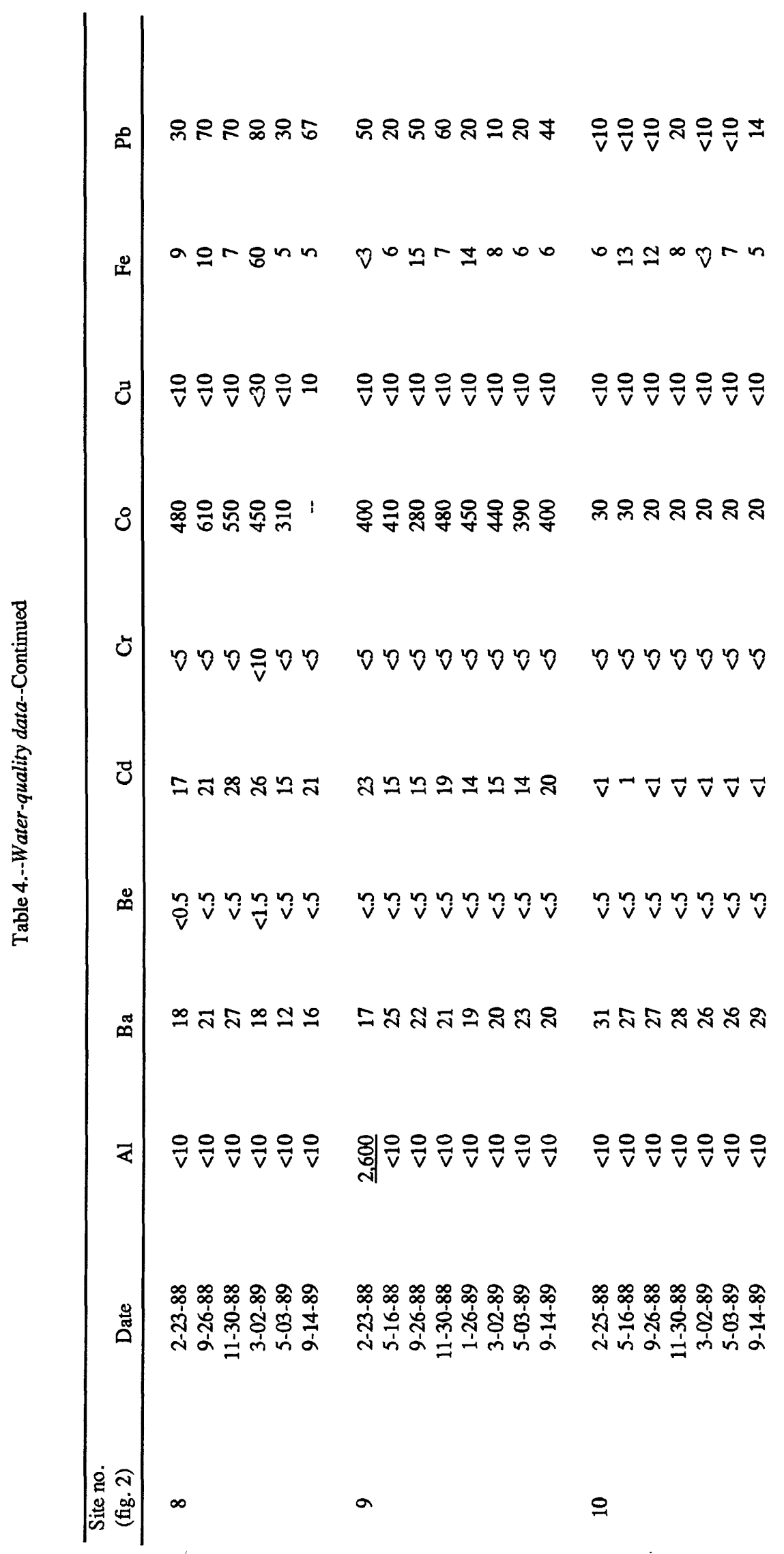




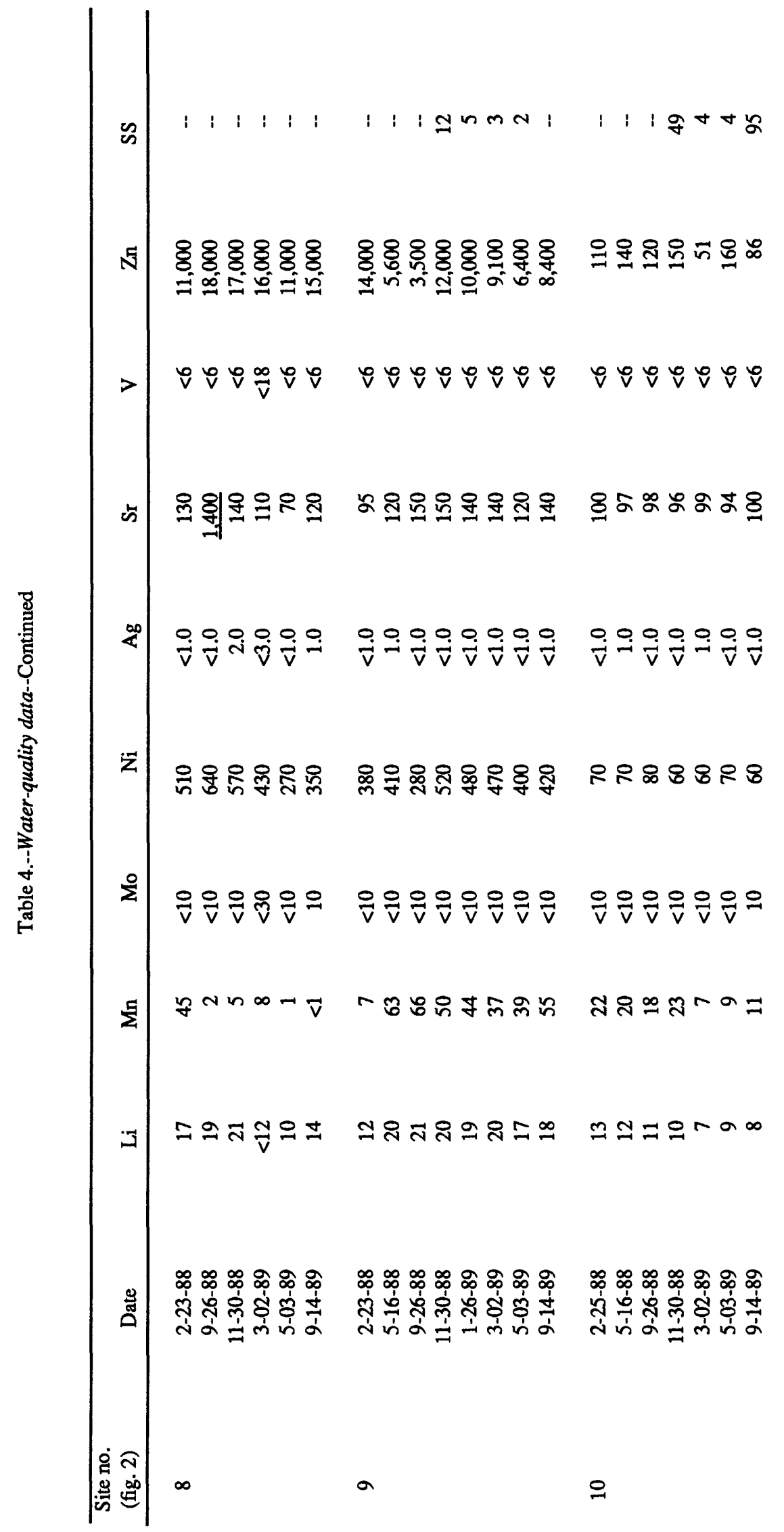




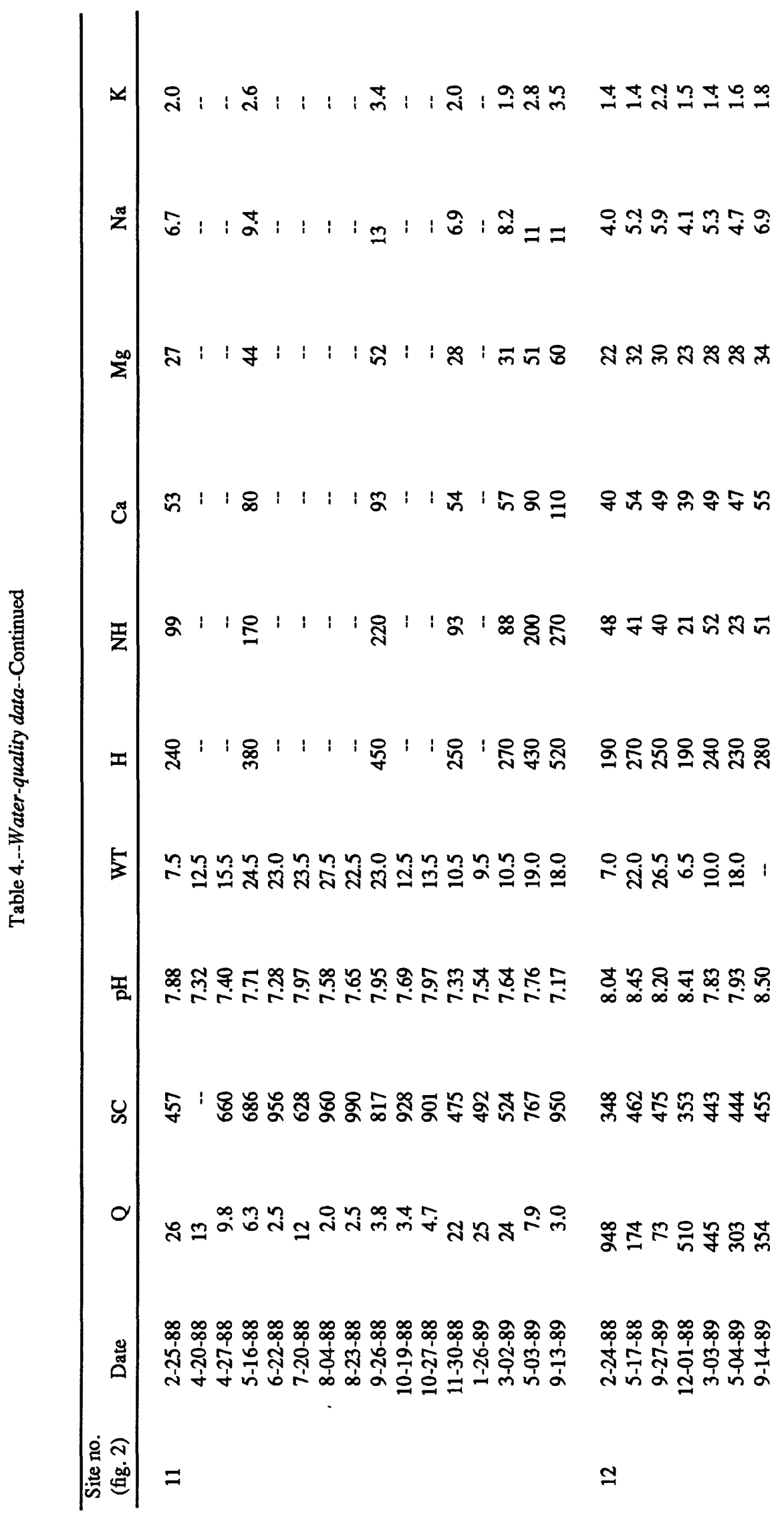




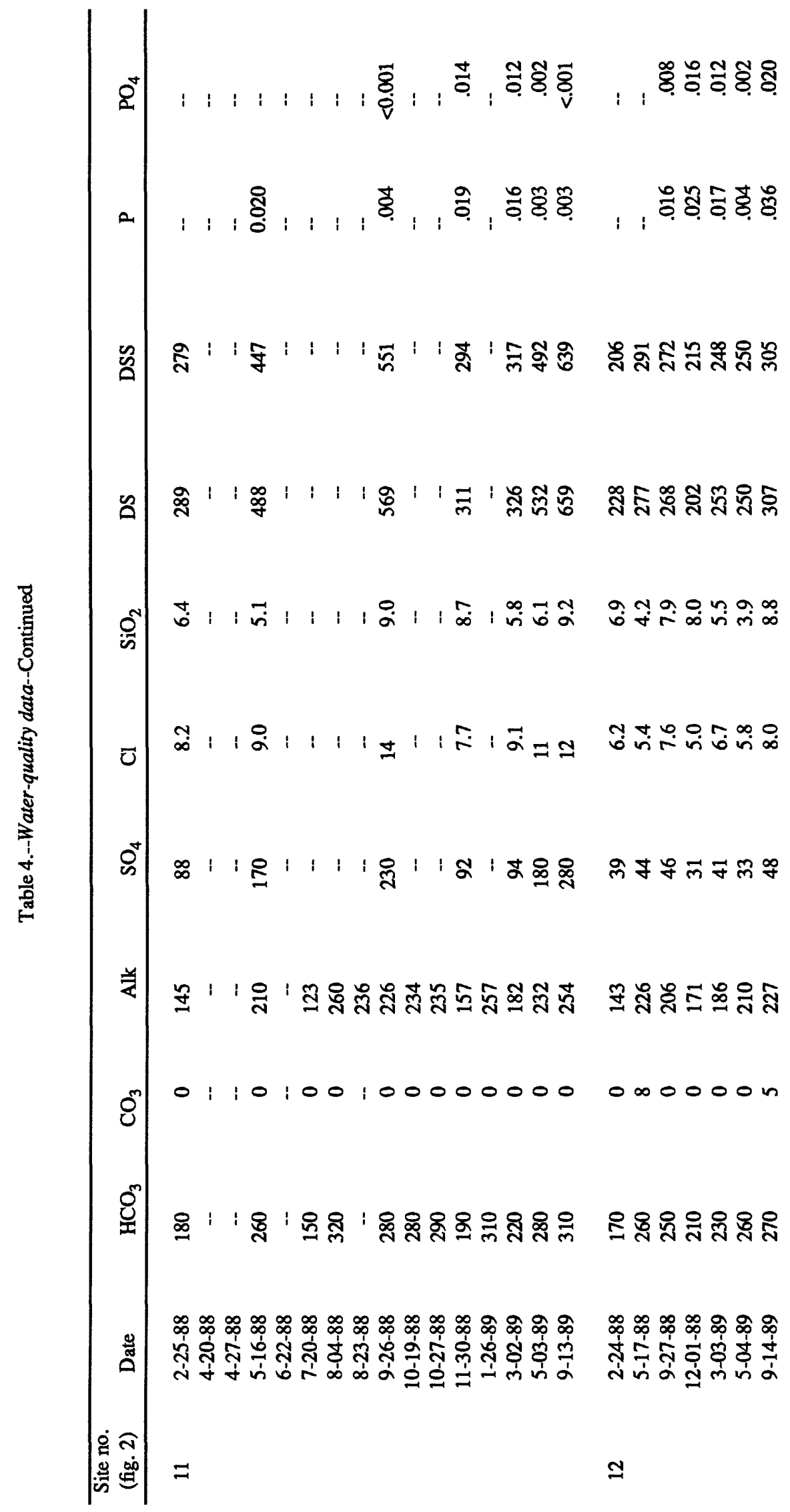




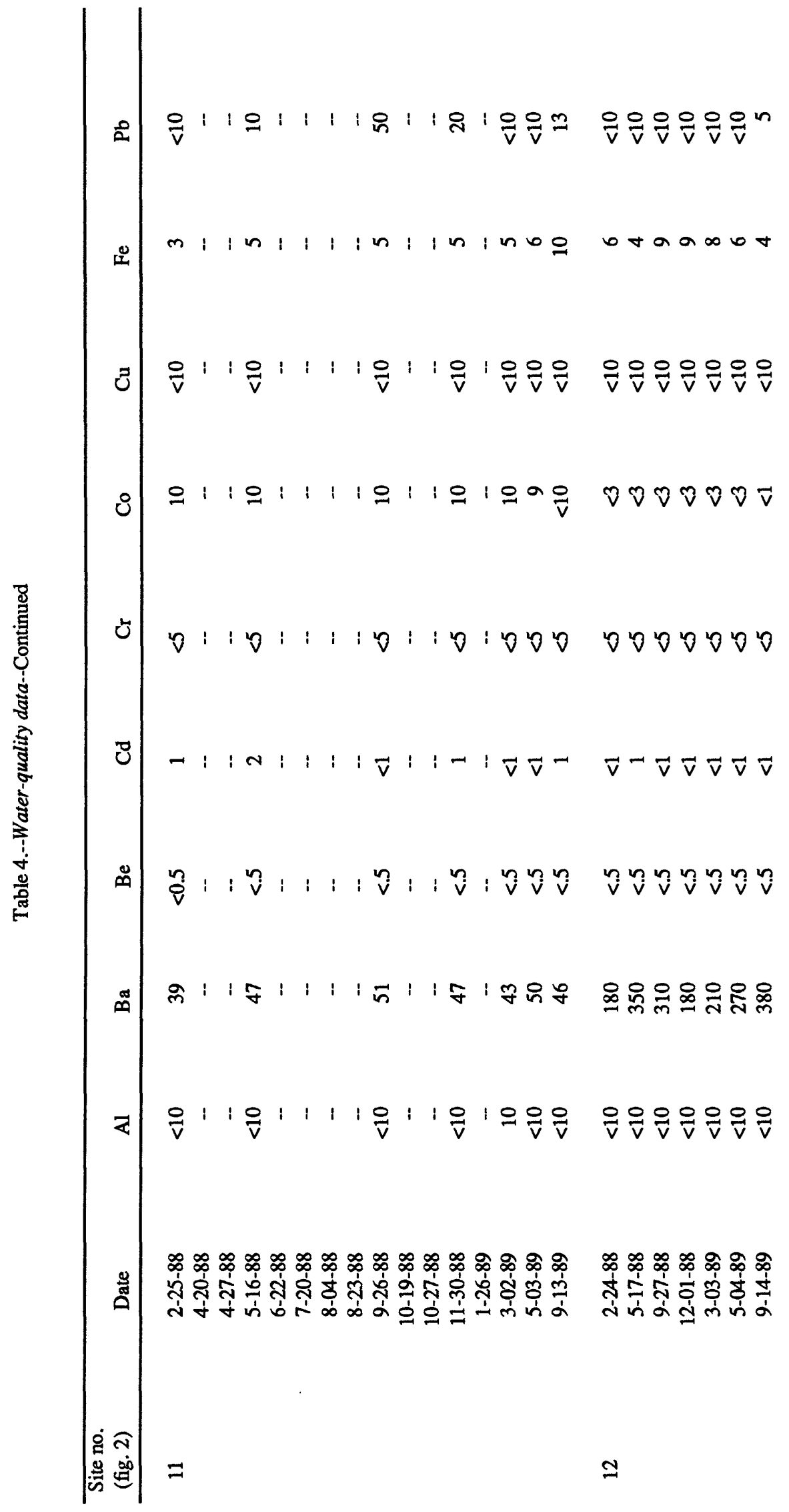




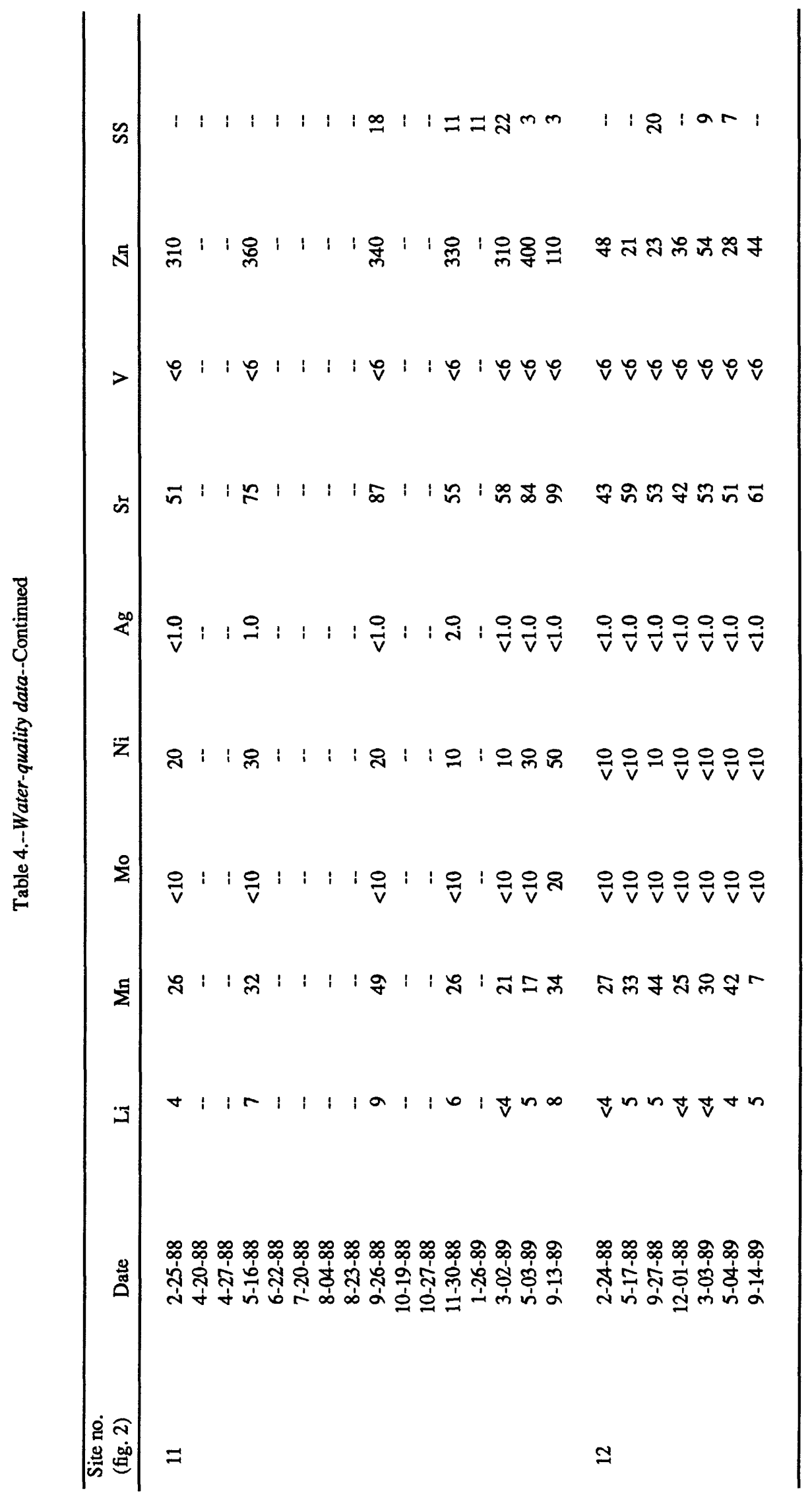




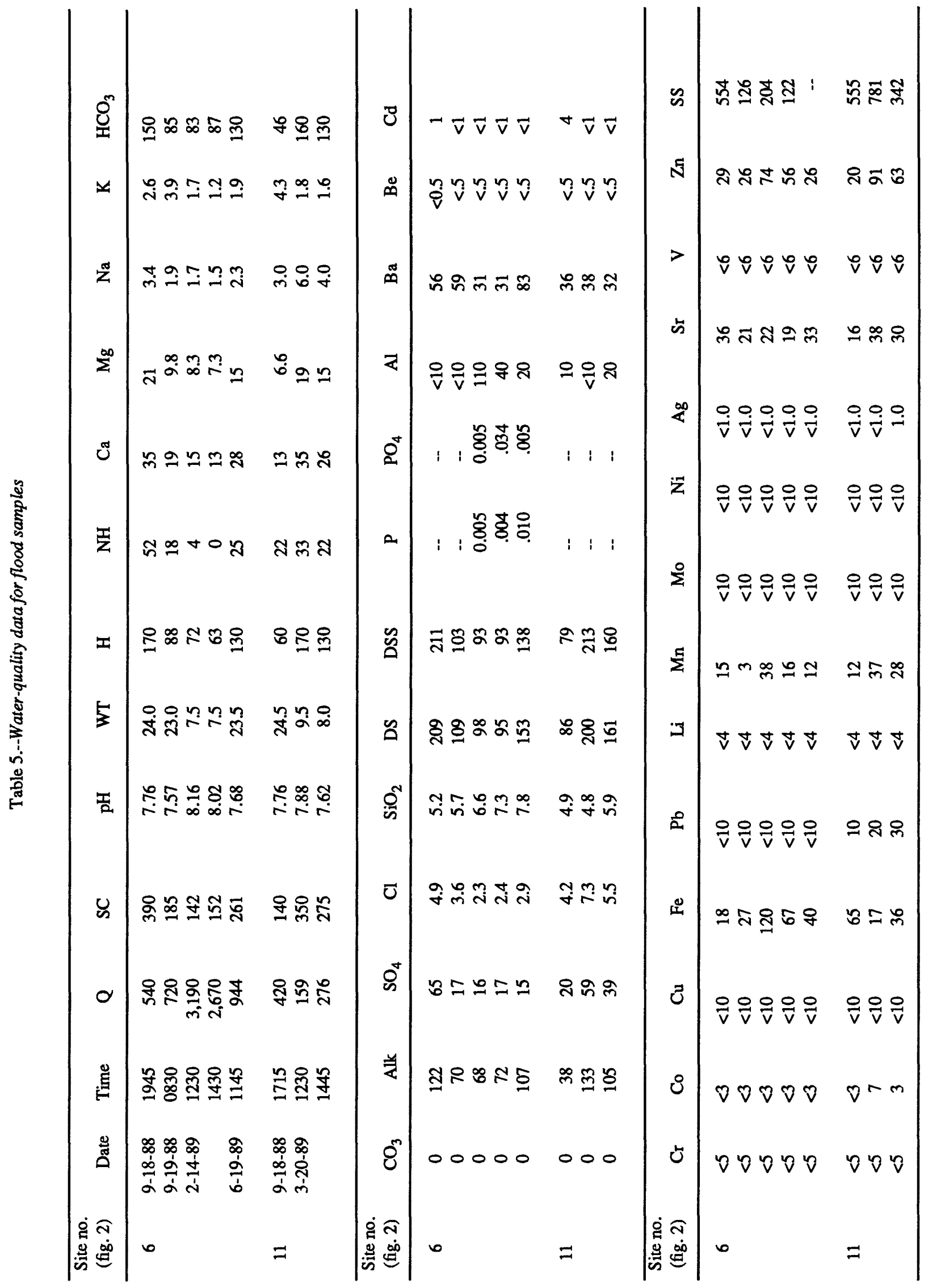




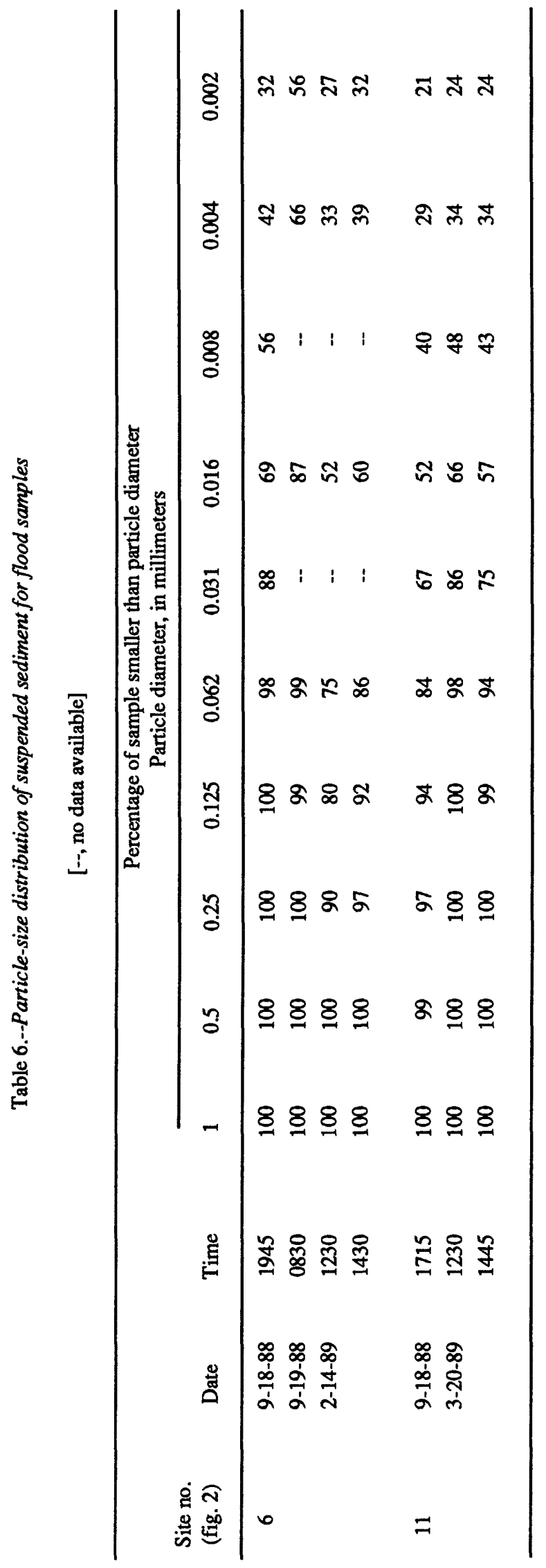




\section{TABLE 7}

\section{ABBREVIATIONS AND REPORTING UNITS FOR CHEMICAL CONSTITUENTS AND NOTATIONS USED IN TABLES}

Q Instantaneous discharge, in cubic feet per second

Al Aluminum, percent

$\mathrm{Ca}$ Calcium, percent

Fe Iron, percent

K Potassium, percent

$\mathrm{Mg}$ Magnesium, percent

$\mathrm{Na}$ Sodium, percent

$\mathrm{P} \quad$ Phosphorus, percent

Ti Titanium, percent

As Arsenic, in micrograms per gram

Ba Barium, in micrograms per gram

Be Beryllium, in micrograms per gram

$\mathrm{Bi}$ Bismuth, in micrograms per gram

Cd Cadmium, in micrograms per gram

Ce Cesium, in micrograms per gram

Cr Chromium, in micrograms per gram

Co Cobalt, in micrograms per gram

$\mathrm{Cu}$ Copper, in micrograms per gram

Eu Europium, in micrograms per gram

$\mathrm{Ga}$ Gallium, in micrograms per gram

Au Gold, in micrograms per gram

Ho Holmium, in micrograms per gram
La Lanthanum, in micrograms per gram

$\mathrm{Pb} \quad$ Lead, in micrograms per gram

Li Lithium, in micrograms per gram

$\mathrm{Mn}$ Manganese, in micrograms per gram

Mo Molybdenum, in micrograms per gram

Nd Neodymium, in micrograms per gram

$\mathrm{Ni}$ Nickel, in micrograms per gram

$\mathrm{Nb}$ Niobium, in micrograms per gram

Sc Scandium, in micrograms per gram

Ag Silver, in micrograms per gram

Sr Strontium, in micrograms per gram

Ta Tantalum, in micrograms per gram

Th Thorium, in micrograms per gram

Sn Tin, in micrograms per gram

U Uranium, in micrograms per gram

V Vanadium, in micrograms per gram

$\mathrm{Yb}$ Ytterbium, in micrograms per gram

Y Yttrium, in micrograms per gram

Zn Zinc, in micrograms per gram

$<\quad$ Less than 


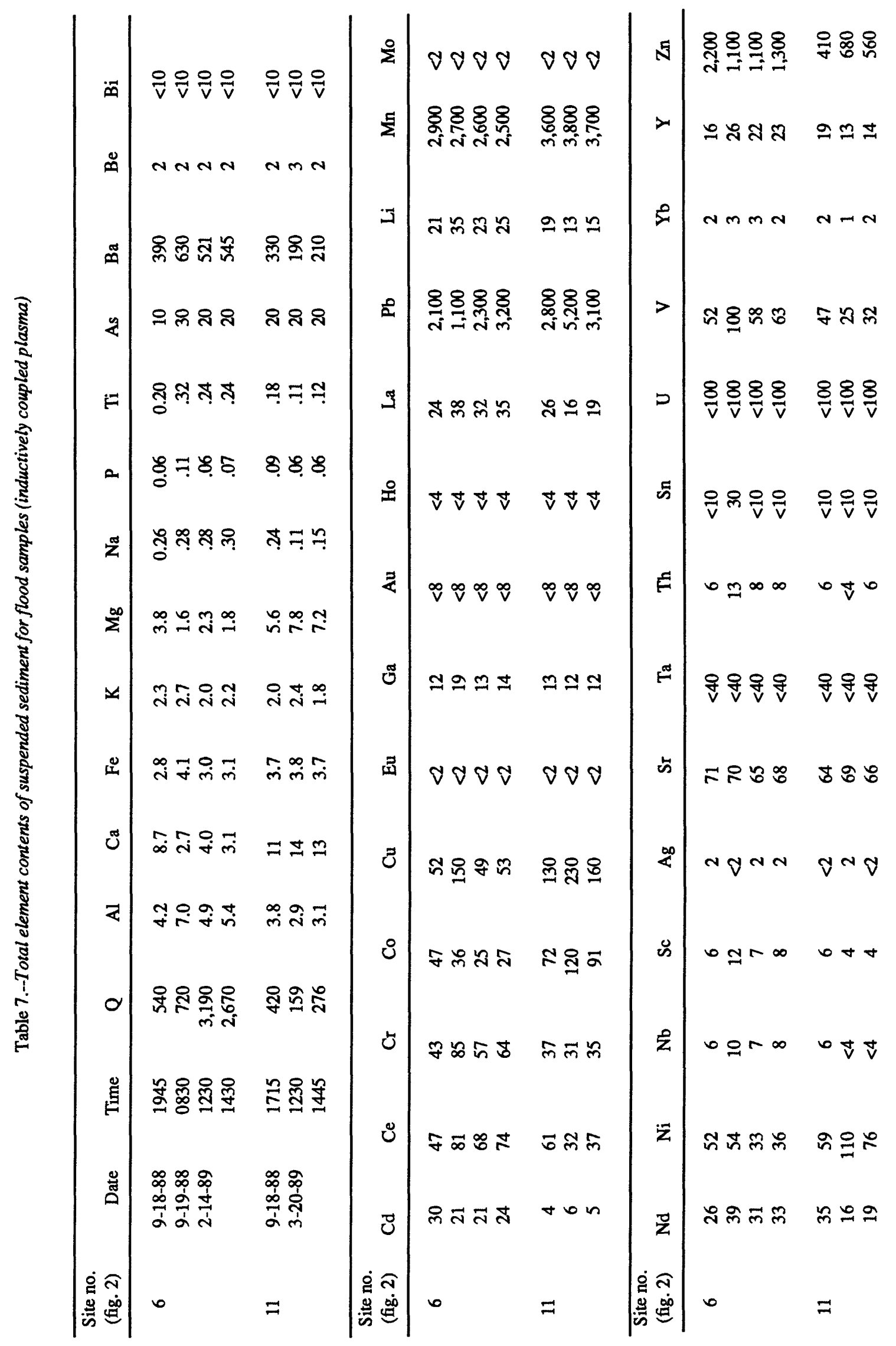


Table 8.--Water-quality sampling sites for seepage runs in the Big River

[DDDMMSS, degrees, minutes seconds]

\begin{tabular}{clcc}
\hline $\begin{array}{c}\text { Site no. } \\
\text { (figs. 7 } \text { and 9) }\end{array}$ & \multicolumn{1}{c}{ Name } & $\begin{array}{c}\text { Latitude } \\
\text { DDMMSS }\end{array}$ & $\begin{array}{c}\text { Longitude } \\
\text { DDDMMSS }\end{array}$ \\
\hline & & & \\
A & Big River upstream from State Highway 8 & 375206 & 0903908 \\
B & Big River below Blay Creek & 375217 & 0903819 \\
C & Big River below Hayden Creek & 375225 & 0903652 \\
D & Big River below Terre du Lac access & 375255 & 0903542 \\
E & Big River & 375309 & 0903509 \\
F & Seep K & 375244 & 0903459 \\
G & Eaton Creek at mouth & 375219 & 0903518 \\
H & Big River at Leadwood Public Access & 375209 & 0903504 \\
3 & Big River at Bonehole & 375232 & 0903258 \\
4 & Drill hole at Bonehole & 375231 & 0903259 \\
J & Big River at east side of Desloge tailings pile & 375258 & 0903241 \\
K & East seep & 375253 & 0903243 \\
L & Quarty seep & 375322 & 0903141 \\
6 & Big River below Desloge & 375322 & 0903107 \\
& & & \\
\hline
\end{tabular}




\section{TABLES 9 AND 10}

\section{ABBREVIATIONS AND REPORTING UNITS FOR CHEMICAL CONSTITUENTS AND NOTATIONS USED IN TABLES}

Q Instantaneous discharge, in cubic feet per second

SC Specific conductance, in microsiemens per centimeter at 25 degrees Celsius

$\mathrm{pH} \quad$ In standard units

WT Water temperature, in degrees Celsius

$\mathrm{H}$ Total hardness, in milligrams per liter as $\mathrm{CaCO}_{3}$

$\mathrm{Ca}$ Dissolved calcium, in milligrams per liter

$\mathrm{Mg}$ Dissolved magnesium, in milligrams per liter

$\mathrm{Na}$ Dissolved sodium, in milligrams per liter

$\mathrm{K}$ Dissolved potassium, in milligrams per liter

$\mathrm{HCO}_{3}$ Bicarbonate, in milligrams per liter

$\mathrm{CO}_{3}$ Carbonate, in milligrams per liter

Alk Alkalinity, total, in milligrams per liter as $\mathrm{CaCO}_{3}$

$\mathrm{SO}_{4}$ Dissolved sulfate, in milligrams per liter

Cl Dissolved chloride, in milligrams per liter

$\mathrm{SiO}_{2}$ Dissolved silica, in milligrams per liter

DS Dissolved solids, residue at 180 degrees Celsius, in milligrams per liter

DSS Dissolved solids, sum of constituents, in milligrams per liter

P Dissolved phosphorous, in milligrams per liter

$\mathrm{PO}_{4}$ Dissolved orthophosphate, in milligrams per liter
Al Dissolved aluminum, in micrograms per liter

Ba Dissolved barium, in micrograms per liter

$\mathrm{Be}$ Dissolved beryllium, in micrograms per liter

Cd Dissolved cadmium, in micrograms per liter

Cr Dissolved chromium, in micrograms per liter

Co Dissolved cadmium, in micrograms per liter

$\mathrm{Cu}$ Dissolved copper, in micrograms per liter

$\mathrm{Fe}$ Dissolved iron, in micrograms per liter

$\mathrm{Pb}$ Dissolved lead, in micrograms per liter

Li Dissolved lithium, in micrograms per liter

Mn Dissolved manganese, in micrograms per liter

Mo Dissolved molybdenum, in micrograms per liter

$\mathrm{Ni}$ Dissolved nickel, in micrograms per liter

Ag Dissolved silver, in micrograms per liter

Sr Dissolved strontium, in micrograms per liter

V Dissolved vanadium, in micrograms per liter

Zn Dissolved zinc, in micrograms per liter

E Estimated

$<\quad$ Less than

-- No data available 


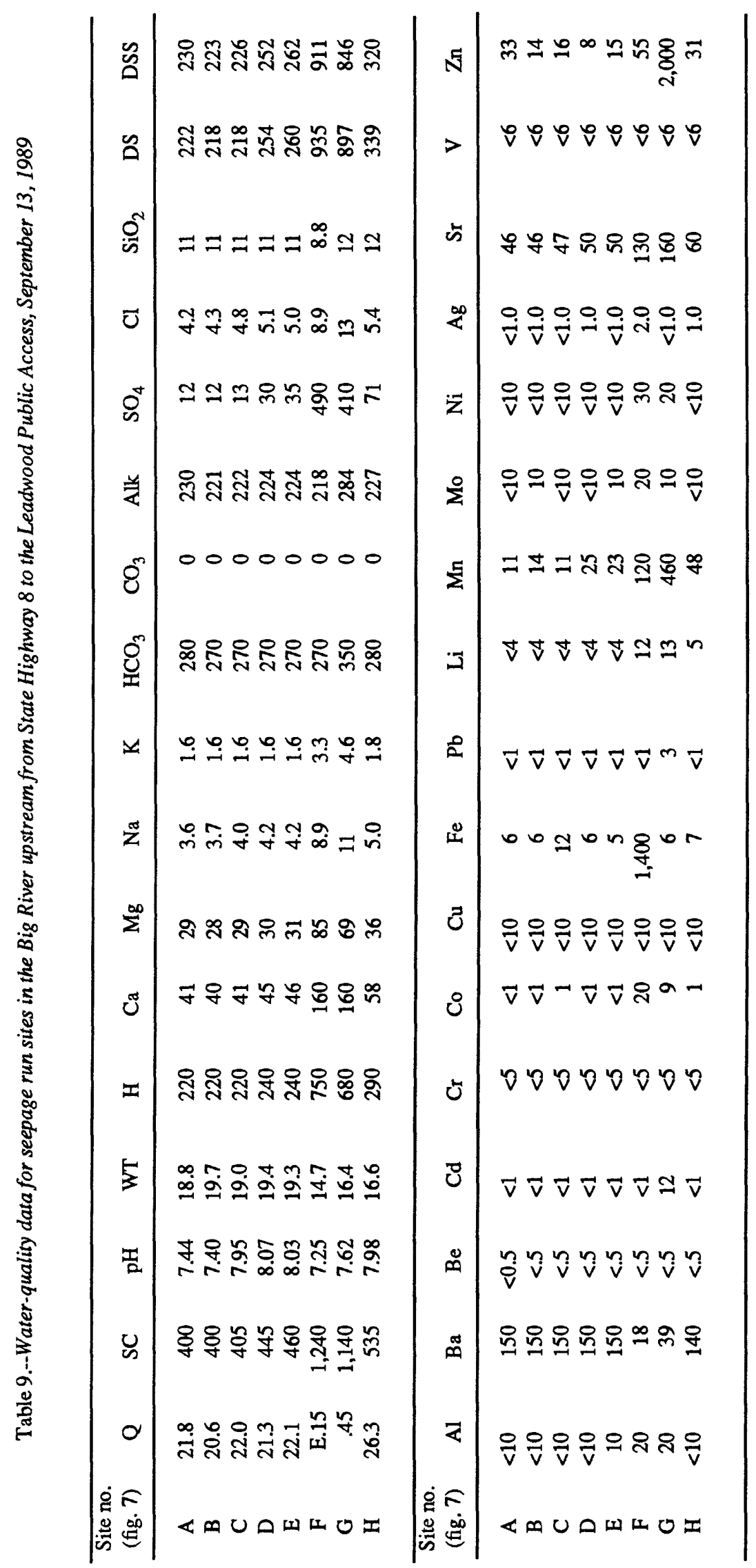




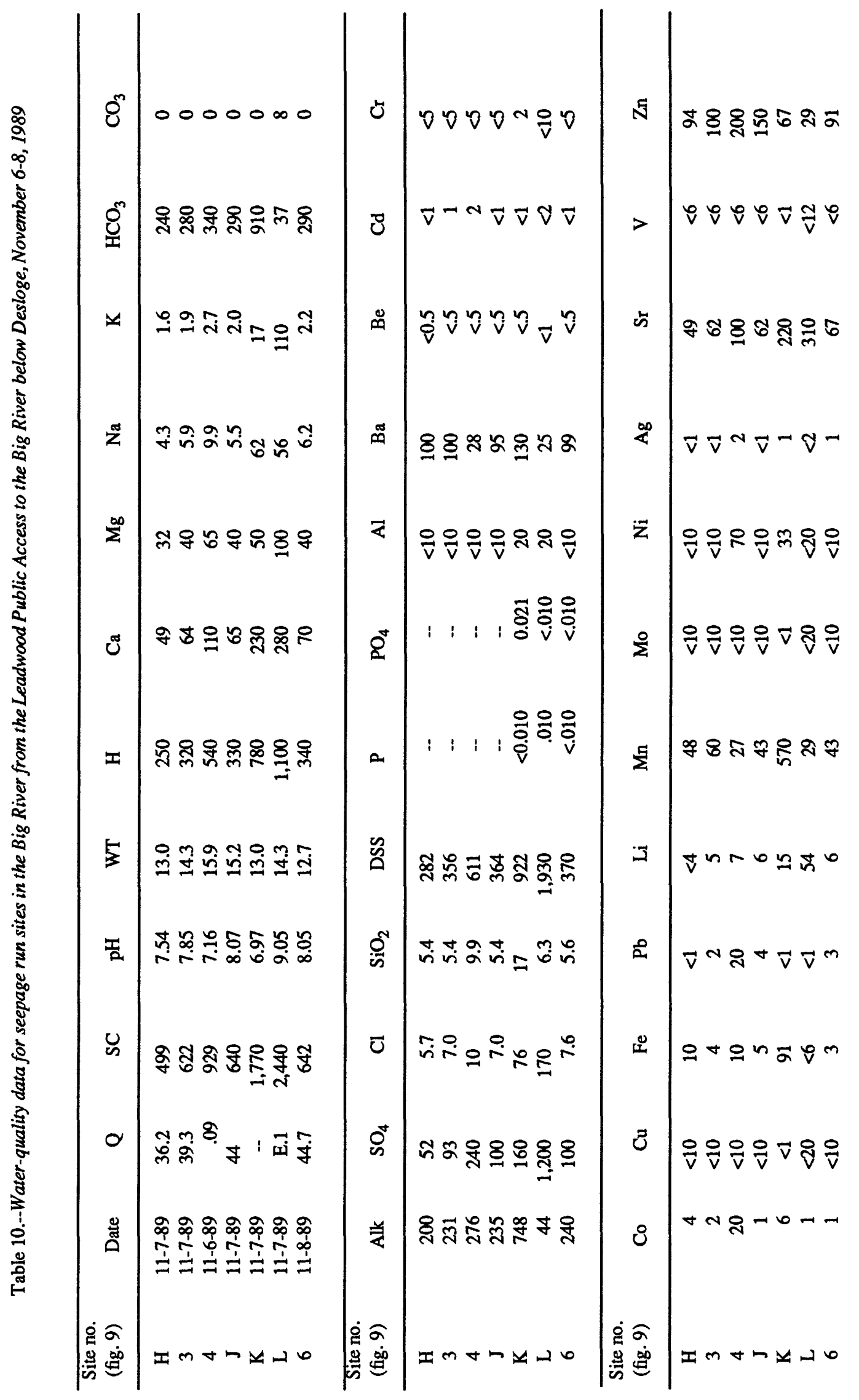




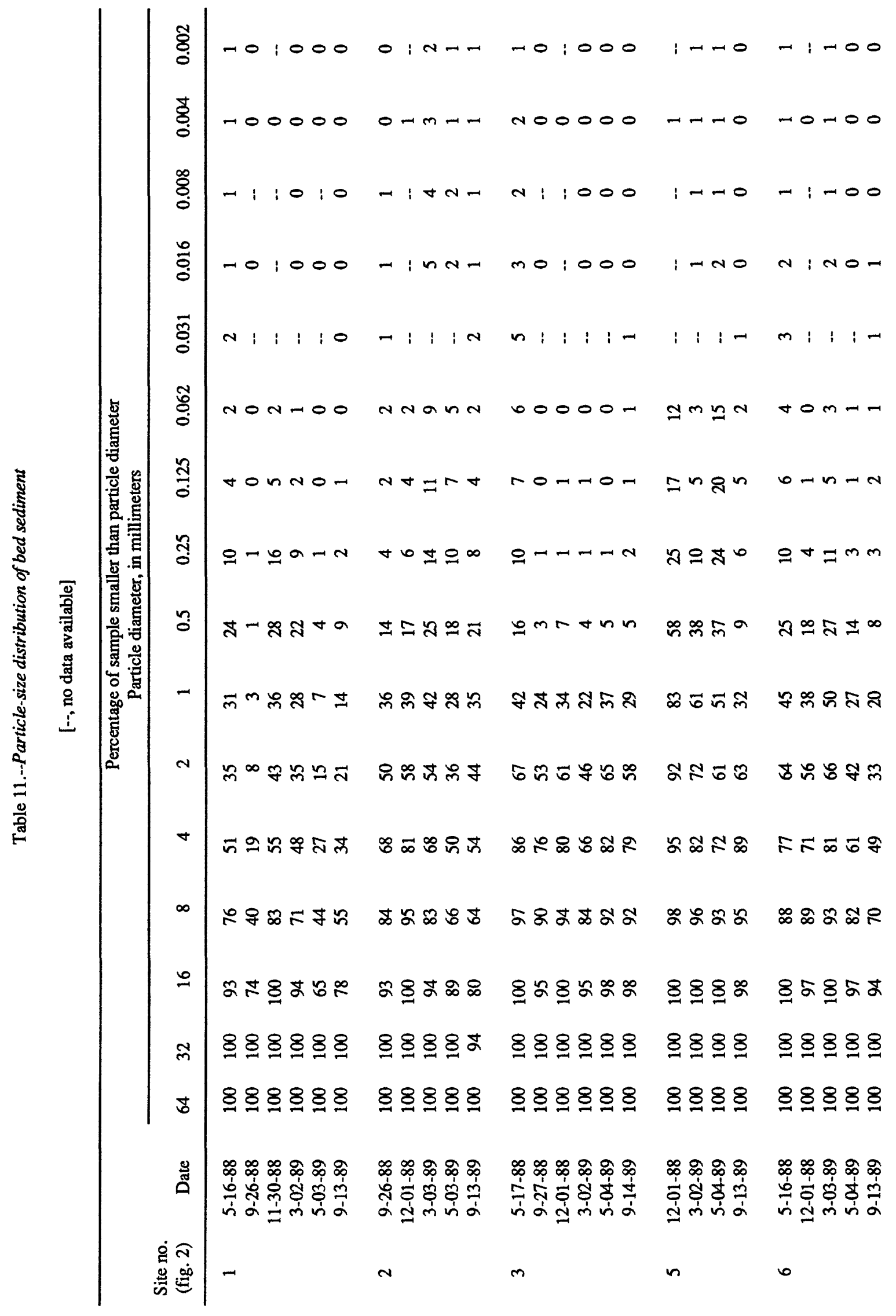




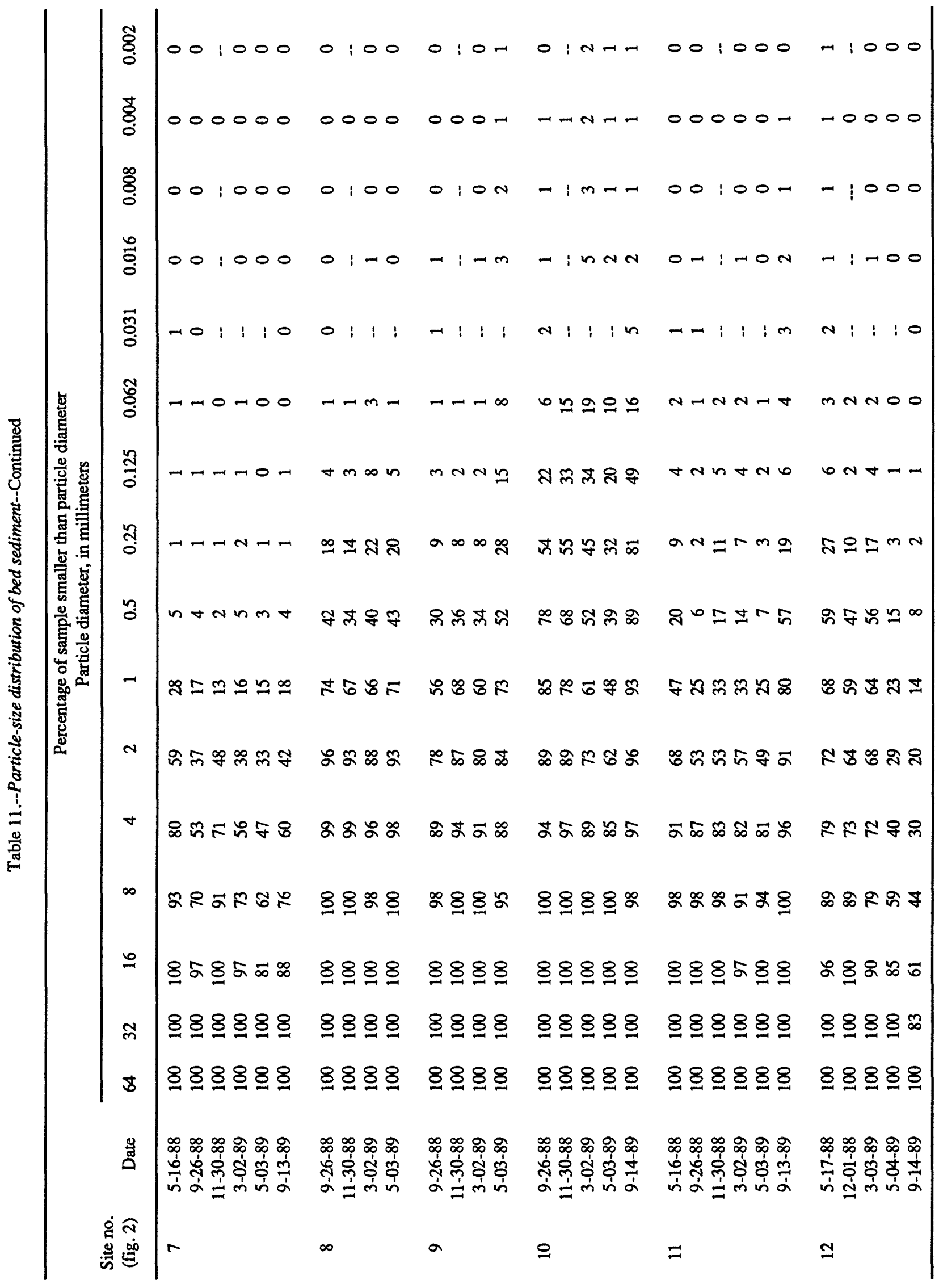




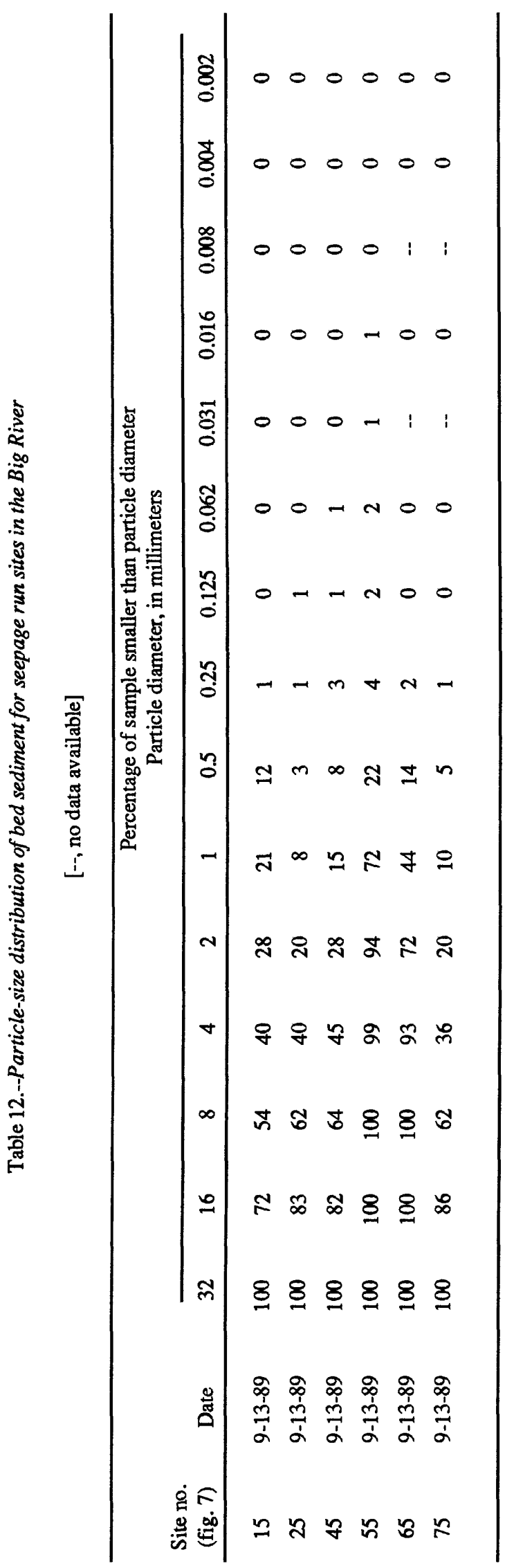


TABLES $13,14,15$, and 16

\section{ABBREVIATIONS AND REPORTING UNITS FOR CHEMICAL CONSTITUENTS AND NOTATIONS USED IN TABLES}

\begin{tabular}{ll}
$\mathrm{Al}$ & Aluminum, percent \\
$\mathrm{Ca}$ & Calcium, percent \\
$\mathrm{Fe}$ & Iron, percent \\
$\mathrm{K}$ & Potassium, percent \\
$\mathrm{Mg}$ & Magnesium, percent \\
$\mathrm{Na}$ & Sodium, percent \\
$\mathrm{P}$ & Phosphorus, percent \\
$\mathrm{Ti}$ & Titanium, percent \\
$\mathrm{Sb}$ & Antimony, in micrograms per gram \\
$\mathrm{As}$ & Arsenic, in micrograms per gram \\
$\mathrm{B}$ & Boron, in micrograms per gram \\
$\mathrm{Ba}$ & Barium, in micrograms per gram \\
$\mathrm{Be}$ & Beryllium, in micrograms per gram \\
$\mathrm{Bi}$ & Bismuth, in micrograms per gram \\
$\mathrm{Cd}$. & Cadmium, in micrograms per gram \\
$\mathrm{Ce}$ & Cesium, in micrograms per gram \\
$\mathrm{Cr}$ & Chromium, in micrograms per gram \\
$\mathrm{Co}$ & Cobalt, in micrograms per gram \\
$\mathrm{Cu}$ & Copper, in micrograms per gram \\
$\mathrm{Eu}$ & Europium, in micrograms per gram \\
$\mathrm{Ga}$ & Gallium, in micrograms per gram \\
$\mathrm{Ge}$ & Germanium, in micrograms per gram \\
$\mathrm{Au}$ & Gold, in micrograms per gram \\
$\mathrm{Ho}$ & Holmium, in micrograms per gram \\
$\mathrm{La}$ & Lanthanum, in micrograms per gram \\
& \\
\hline
\end{tabular}

$\mathrm{Pb} \quad$ Lead, in micrograms per gram

Li Lithium, in micrograms per gram

Mn Manganese, in micrograms per gram

Mo Molybdenum, in micrograms per gram

Nd Neodymium, in micrograms per gram

$\mathrm{Ni}$ Nickel, in micrograms per gram

$\mathrm{Nb}$ Niobium, in micrograms per gram

Sc Scandium, in micrograms per gram

Ag Silver, in micrograms per gram

$\mathrm{Sr}$ Strontium, in micrograms per gram

Ta Tantalum, in micrograms per gram

Th Thorium, in micrograms per gram

Sn Tin, in micrograms per gram

W Tungsten, in micrograms per gram

U Uranium, in micrograms per gram

V Vanadium, in micrograms per gram

Yb Ytterbium, in micrograms per gram

Y Ytrium, in micrograms per gram

Zn Zinc, in micrograms per gram

Zr Zirconium, in micrograms per gram

$<\quad$ Less than

-- No data available

$>\quad$ Greater than

$\mu \mathrm{m} \quad$ Micrometer

$\mathrm{t}$ Detected in trace quantities, but not quantifiable 


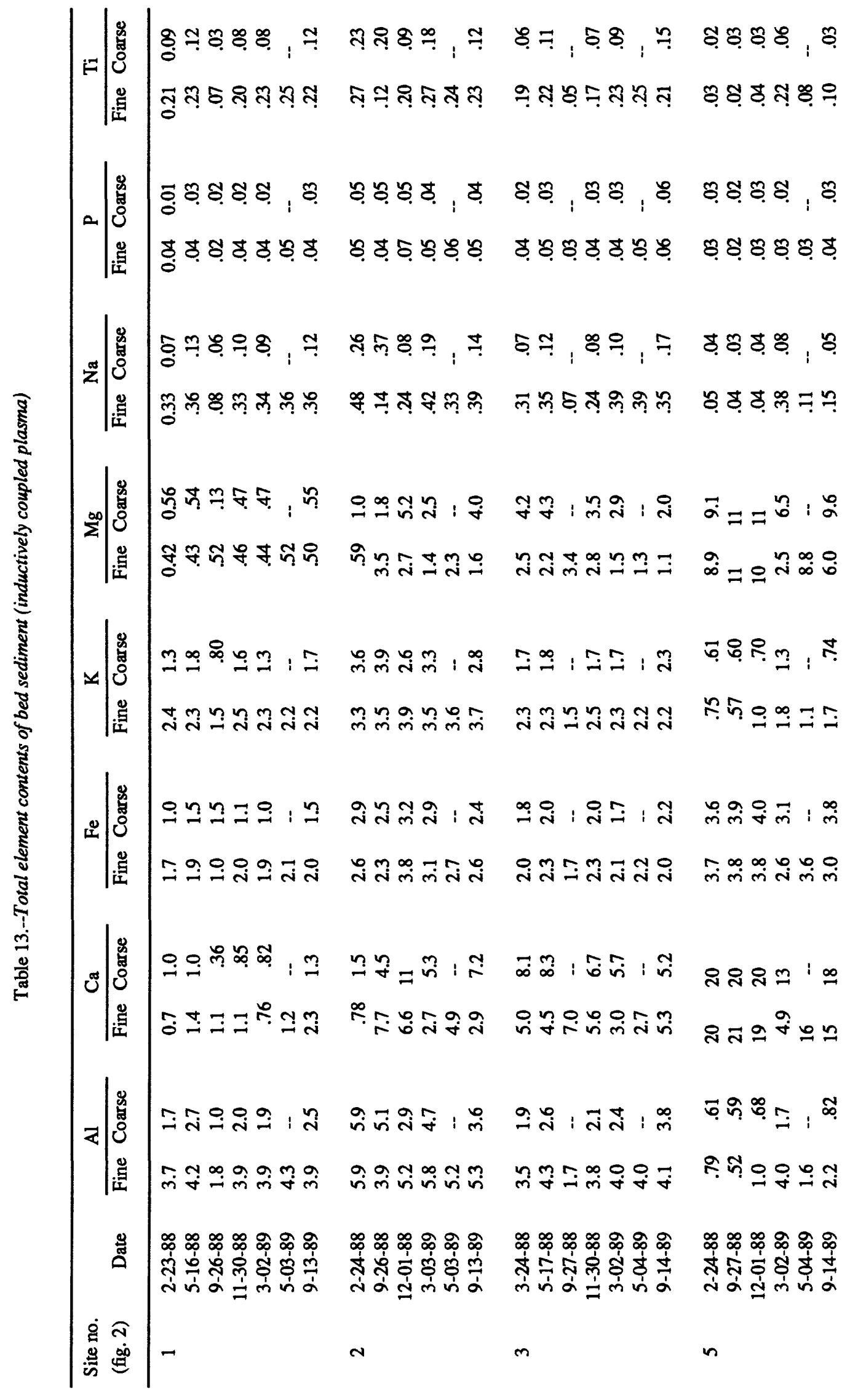




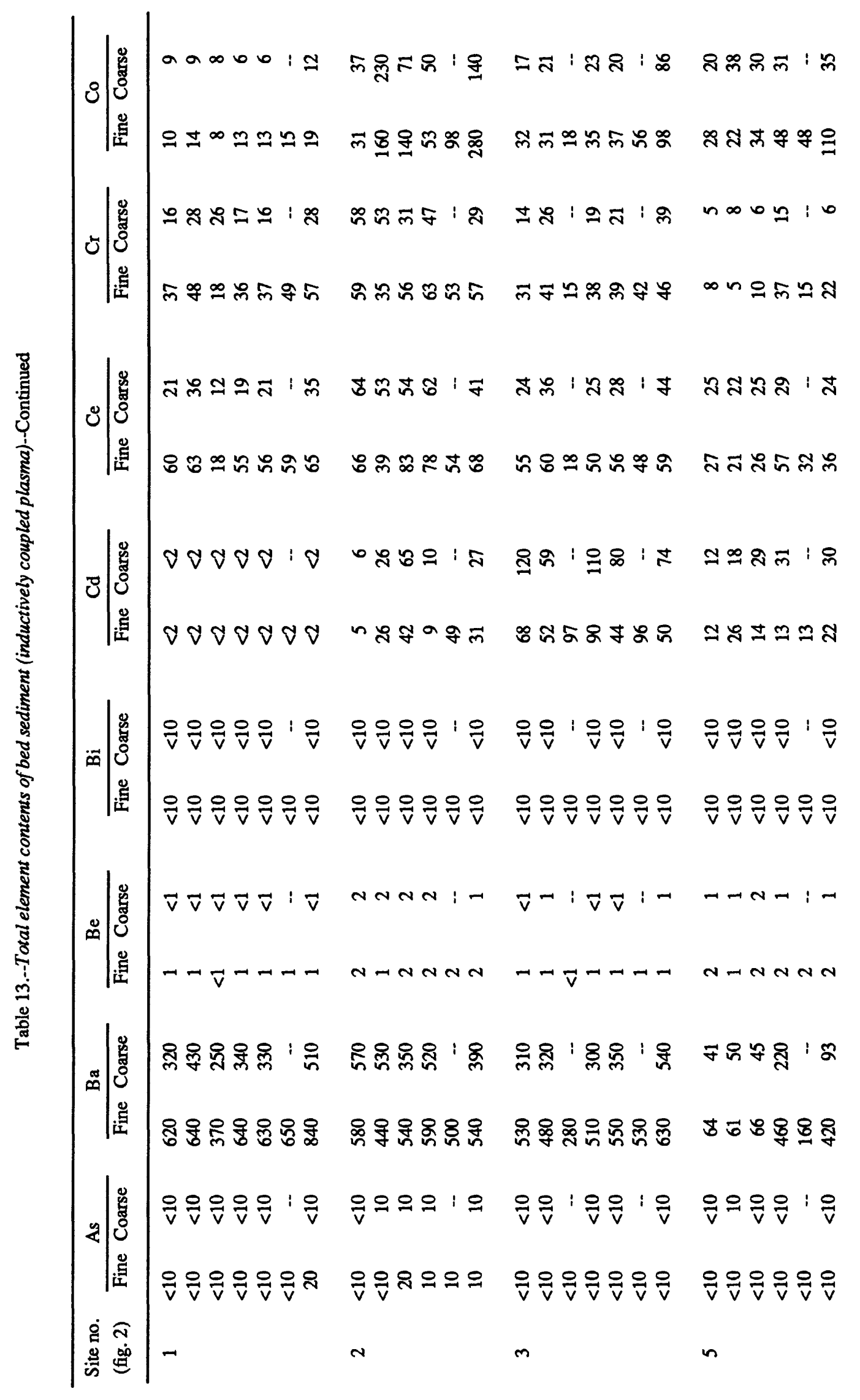




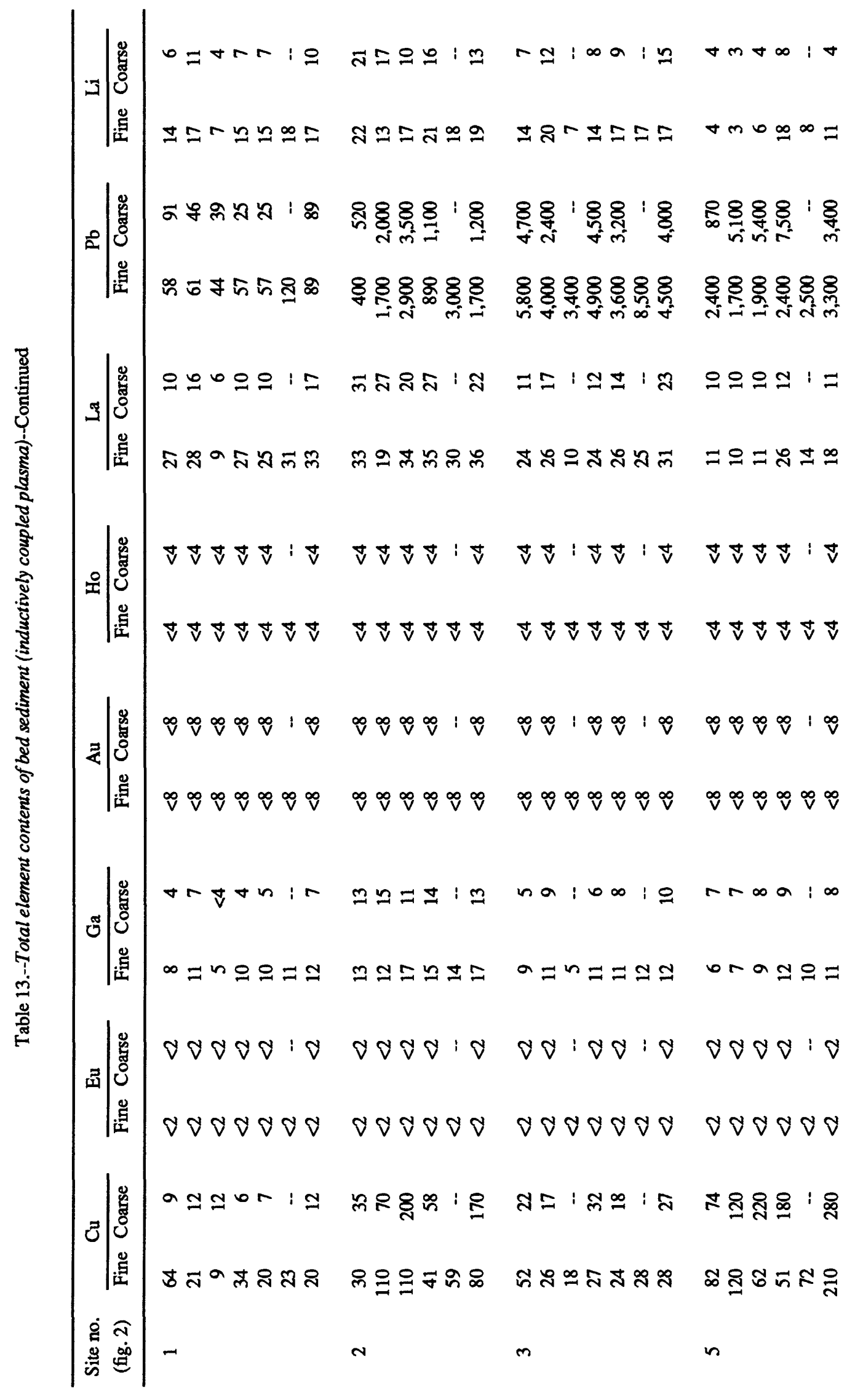




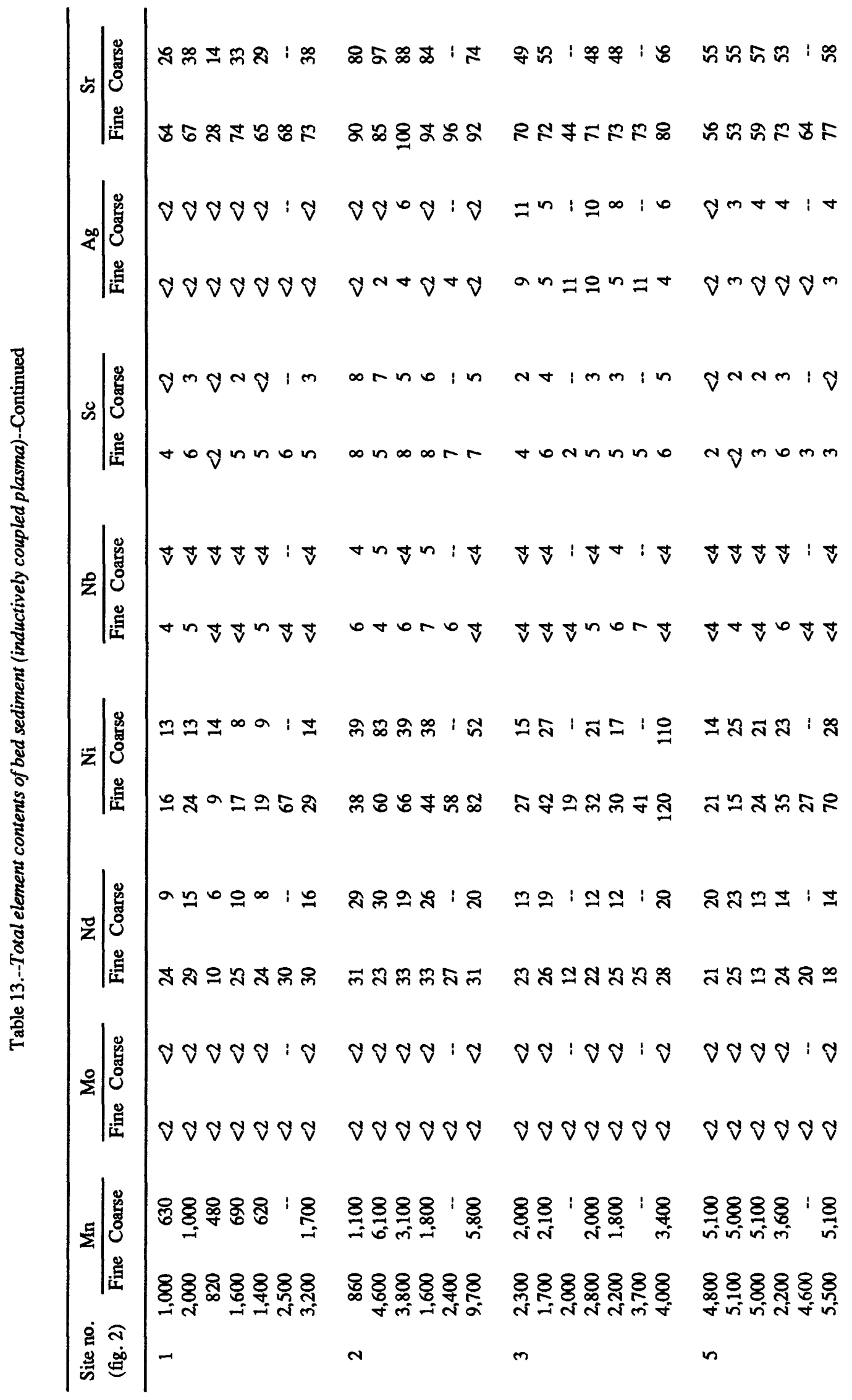




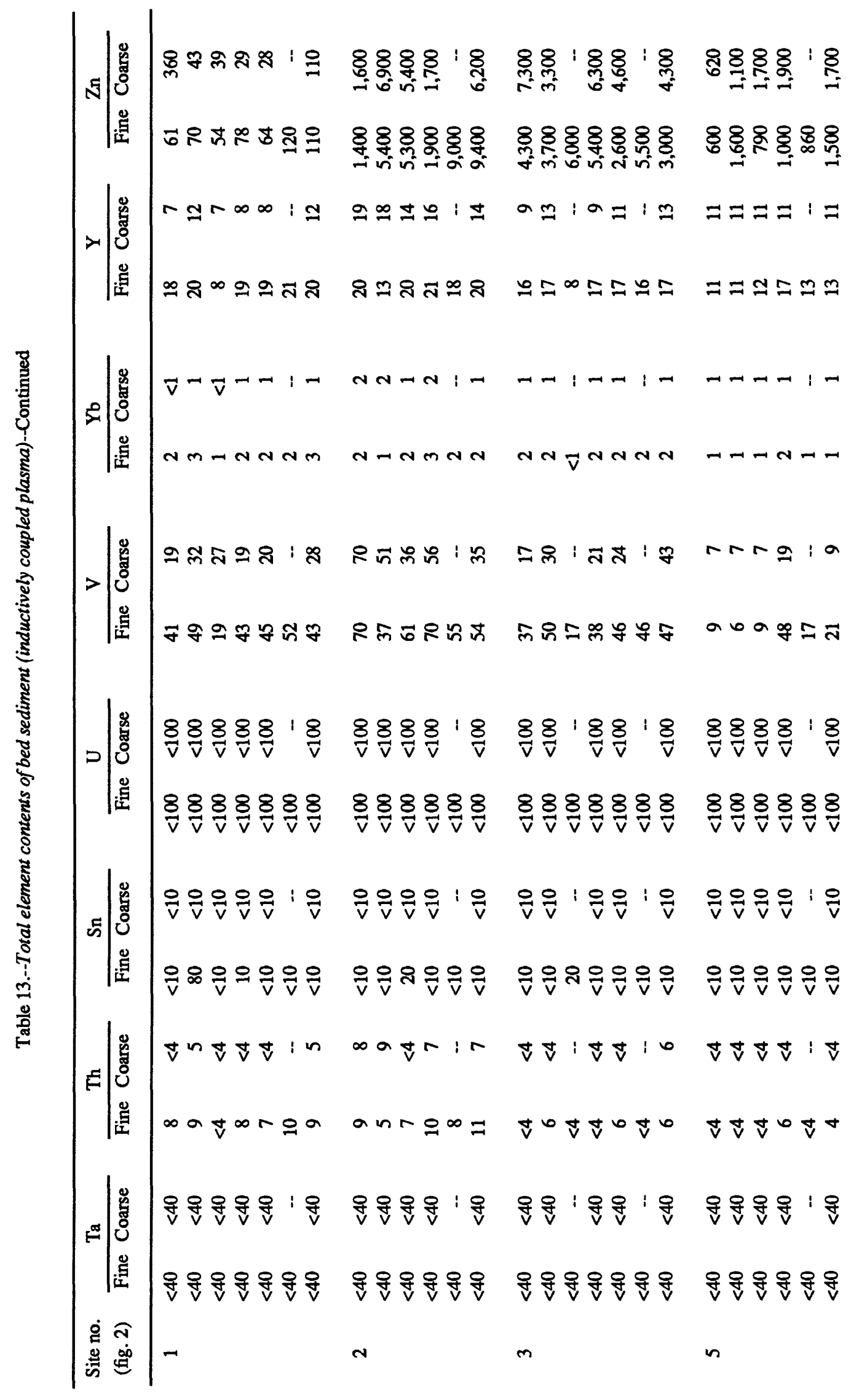




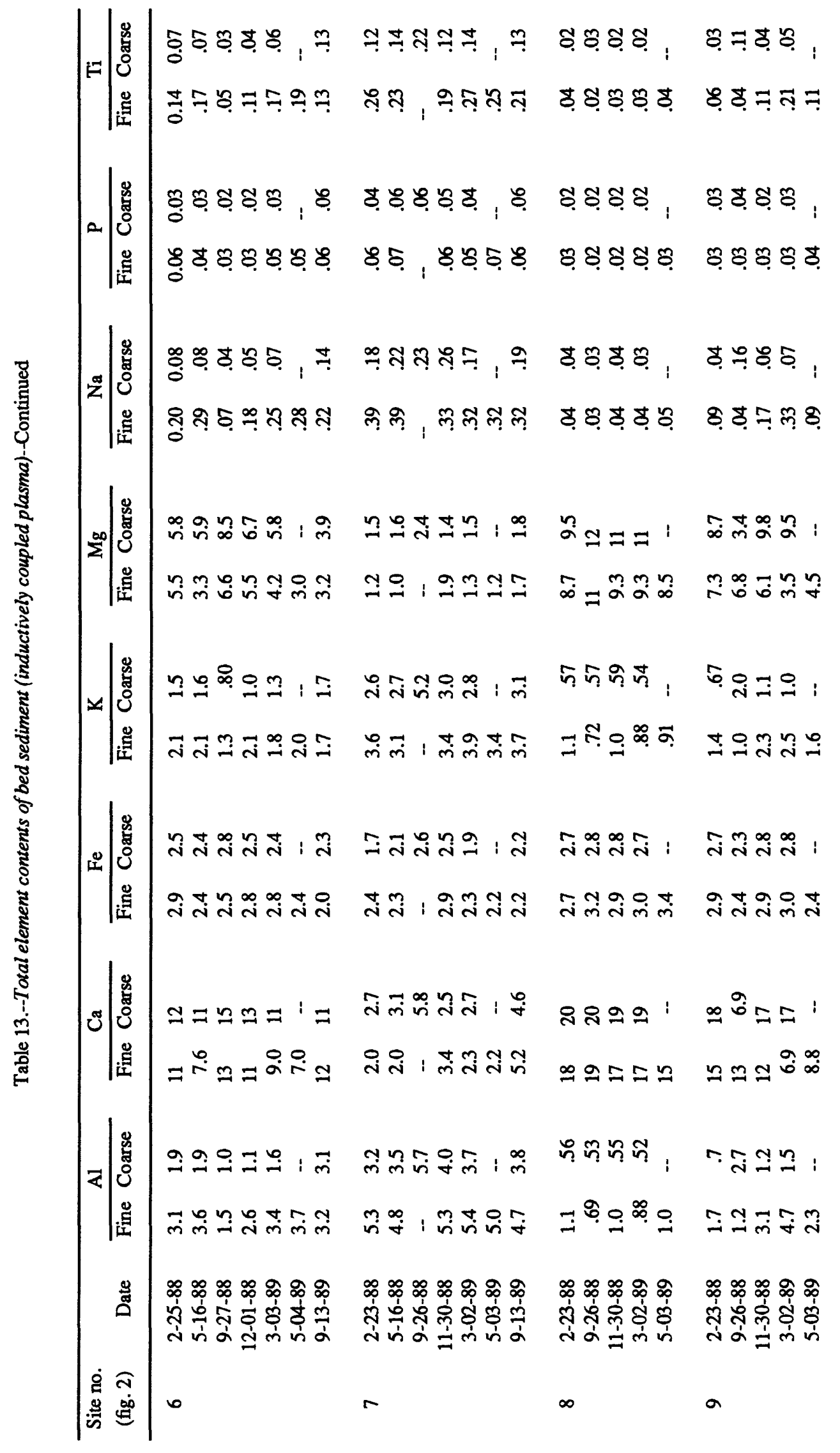




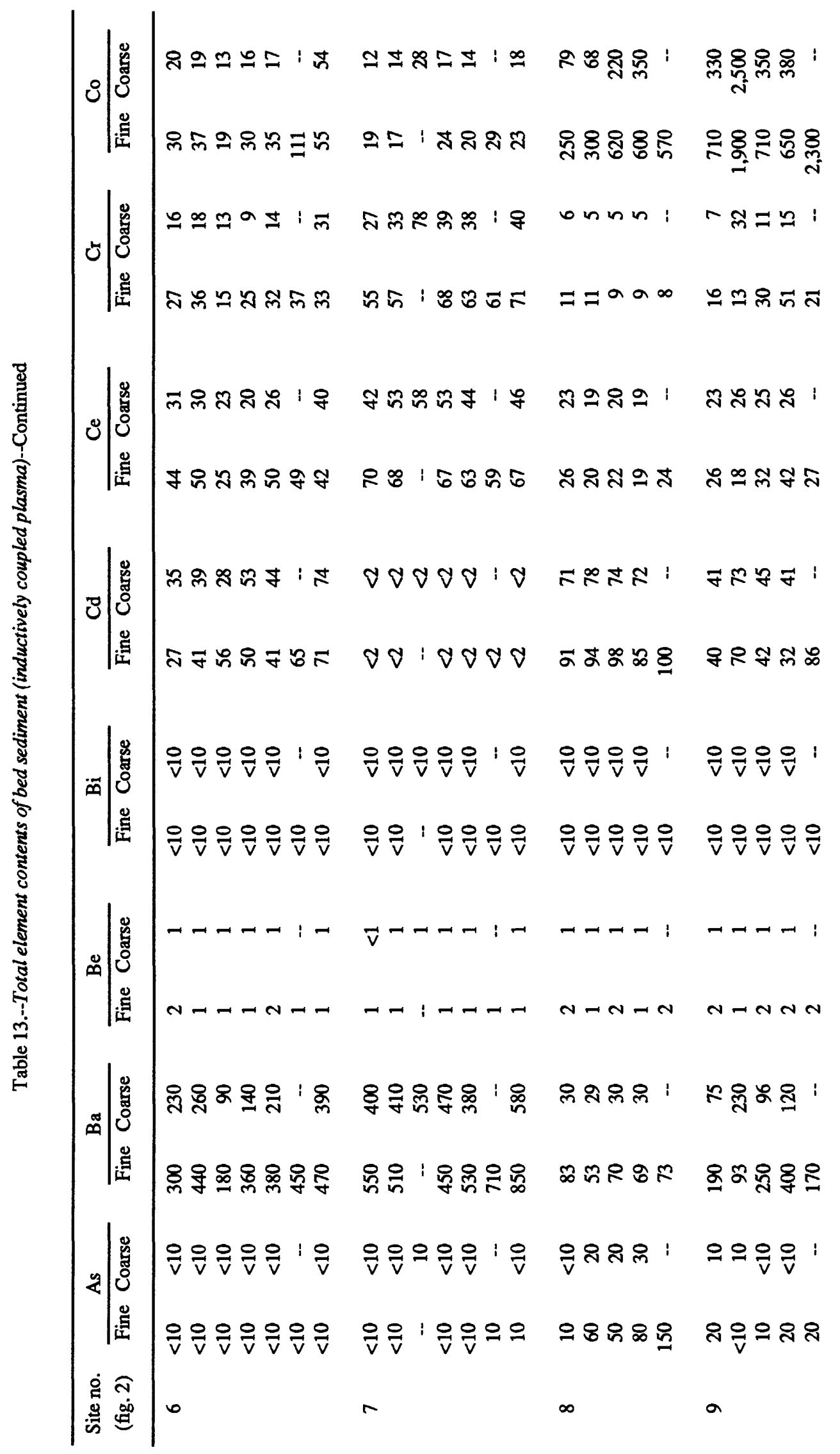




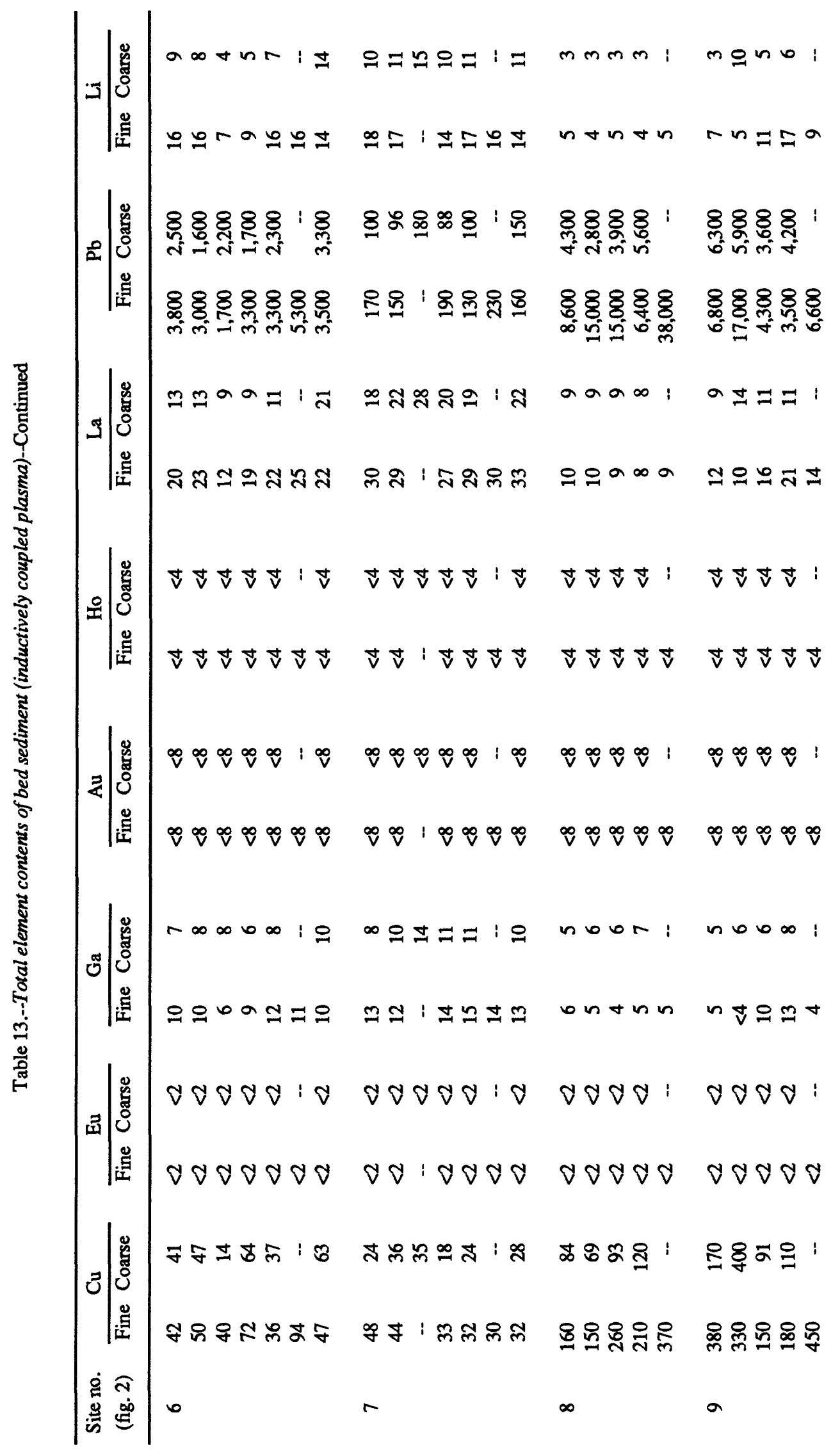




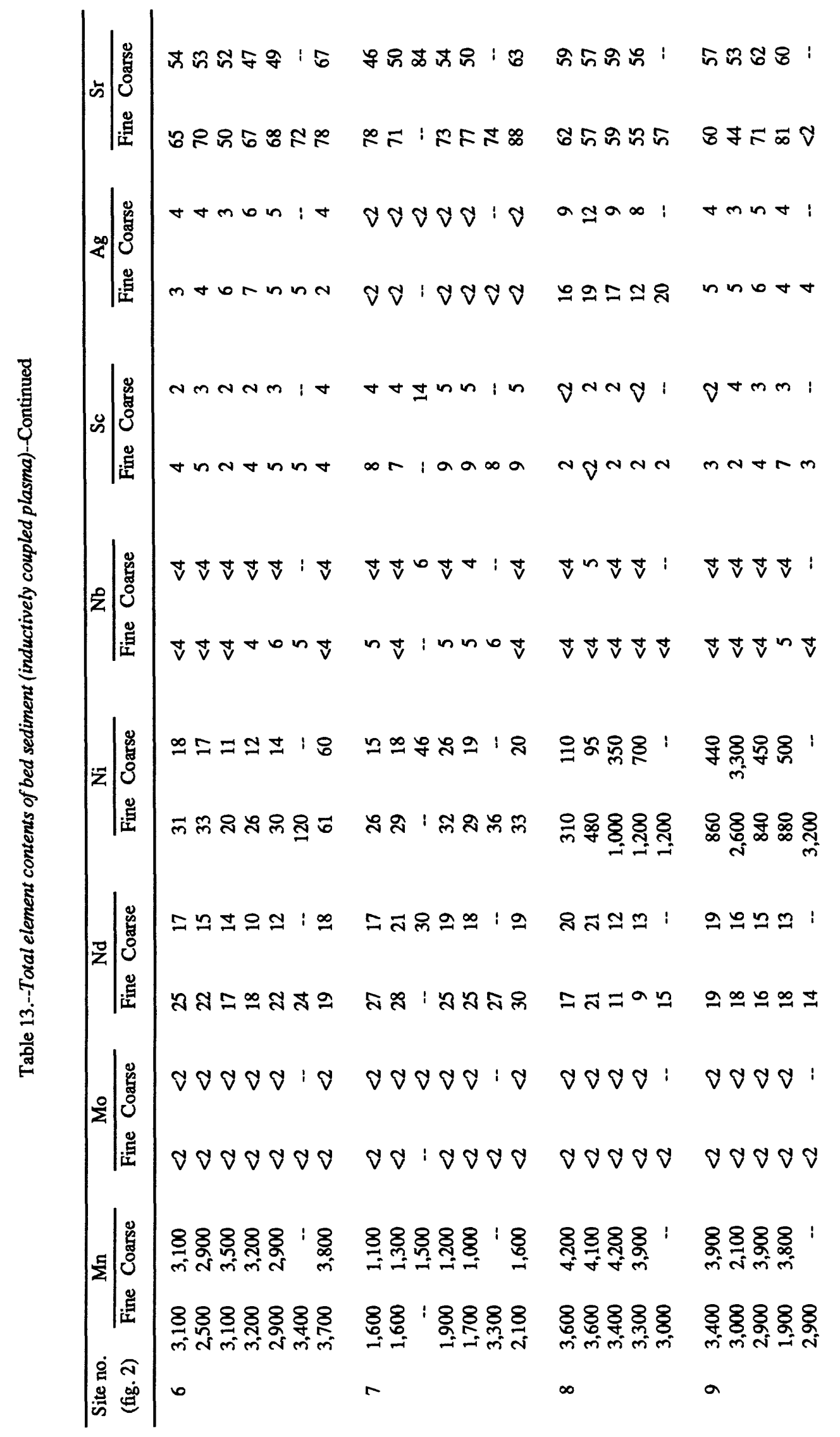




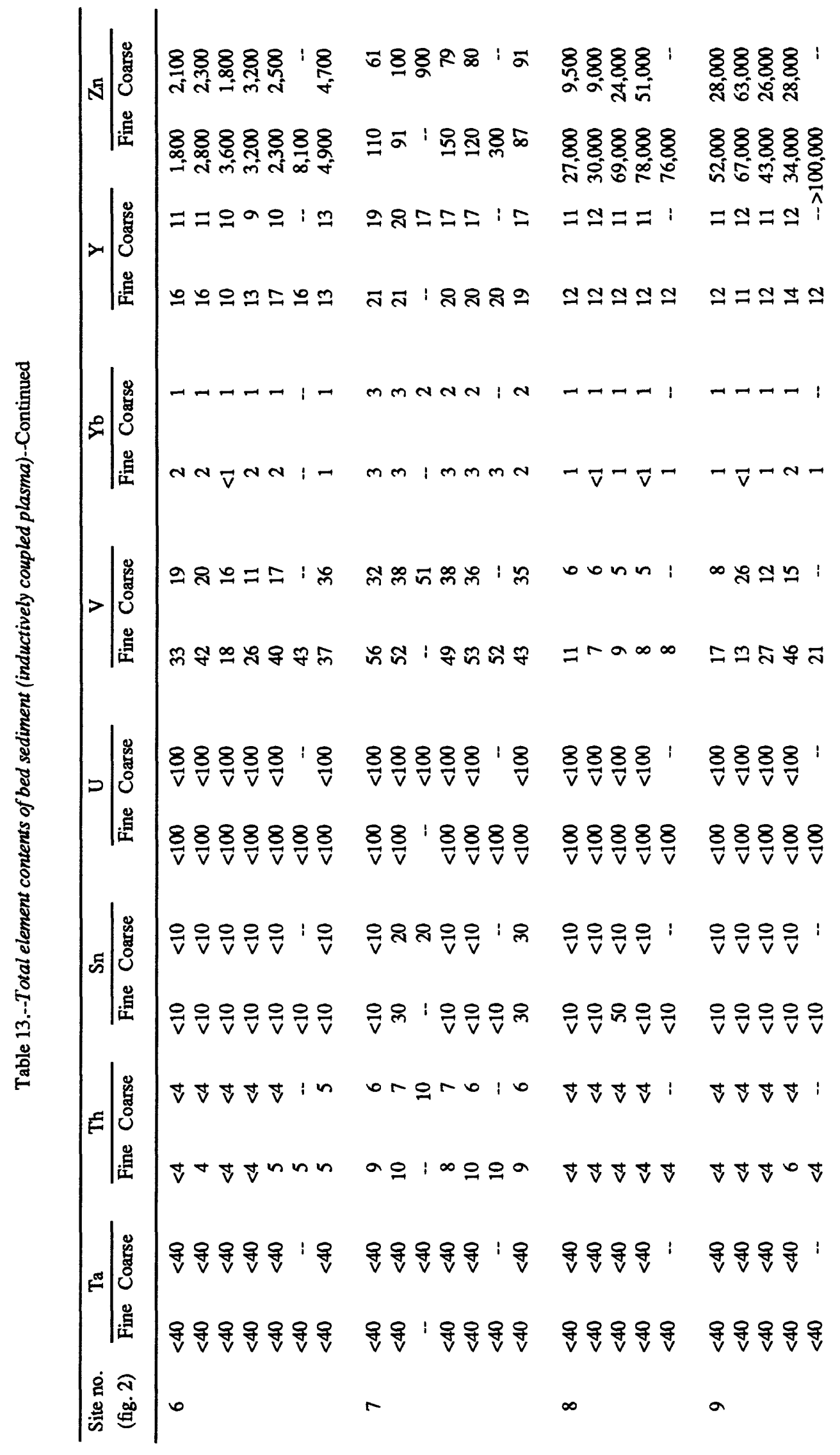




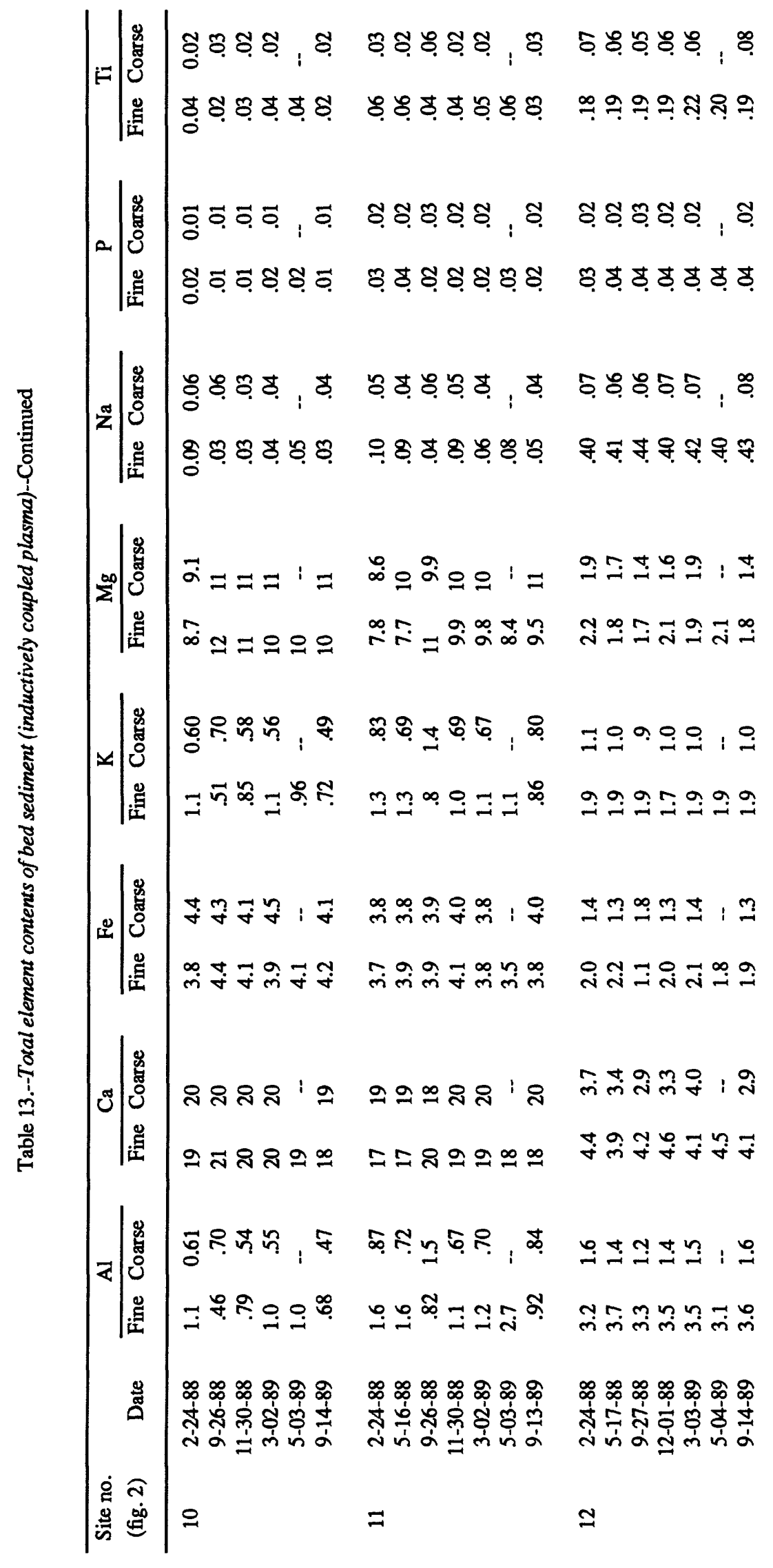




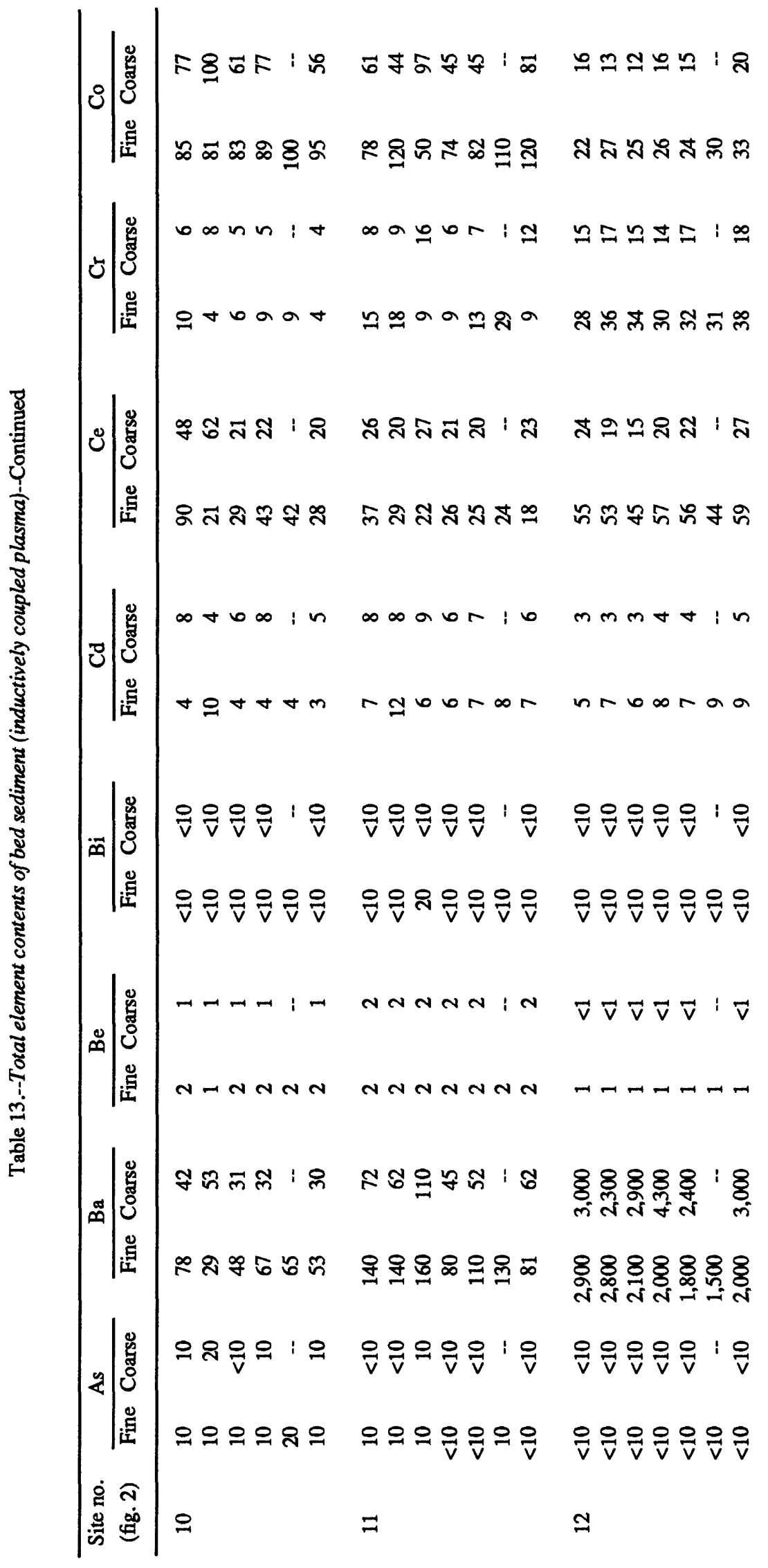




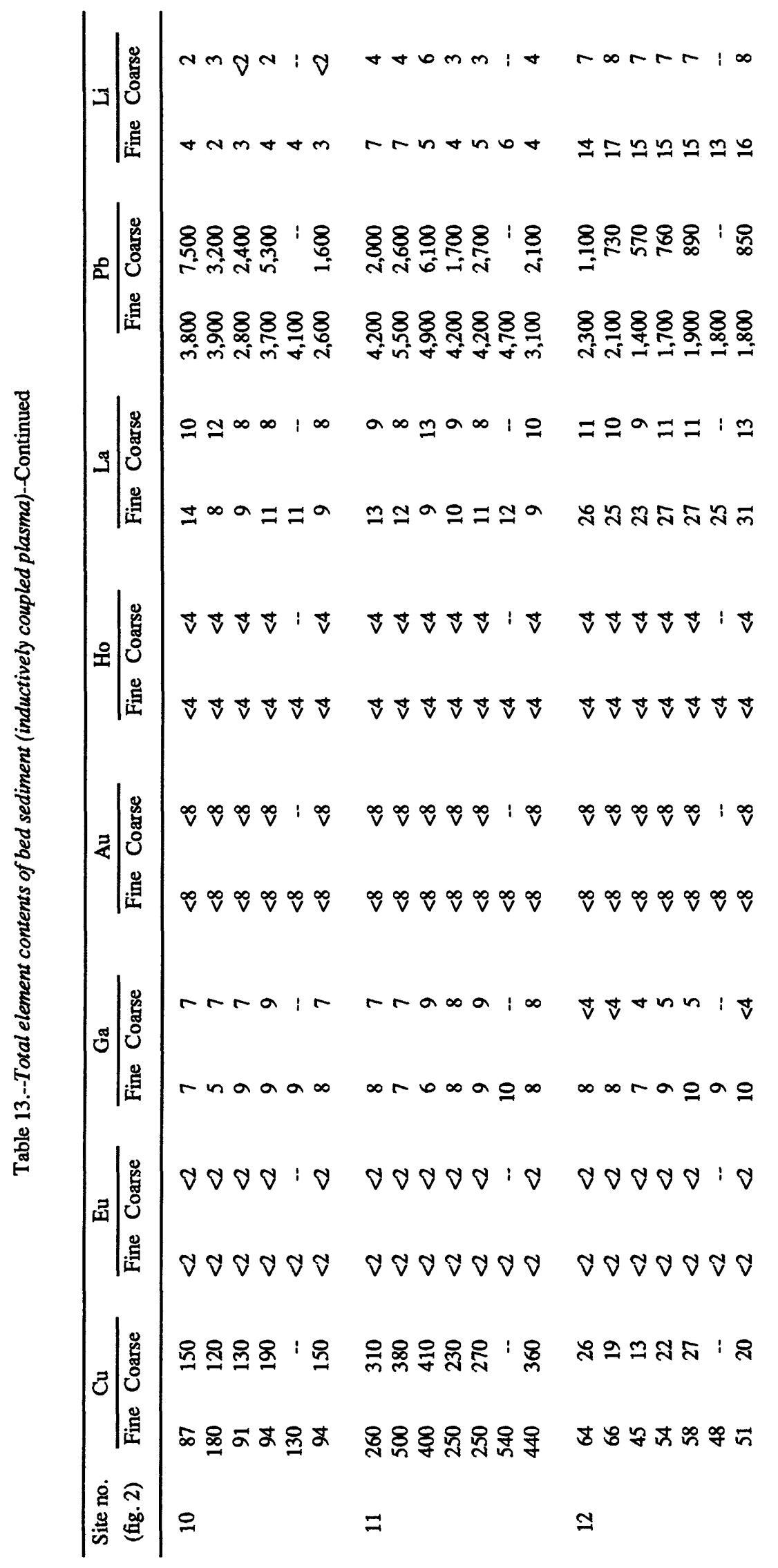




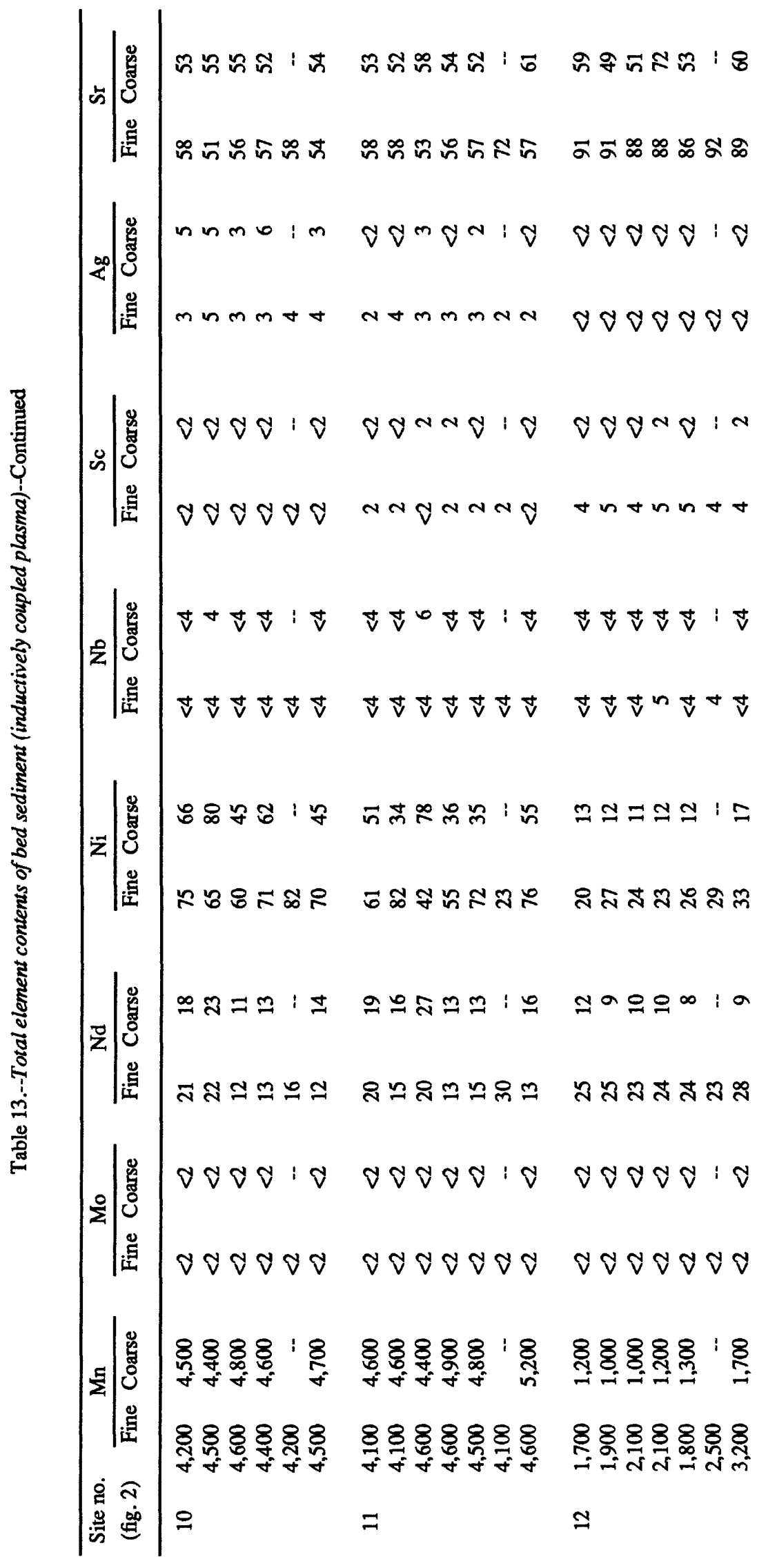




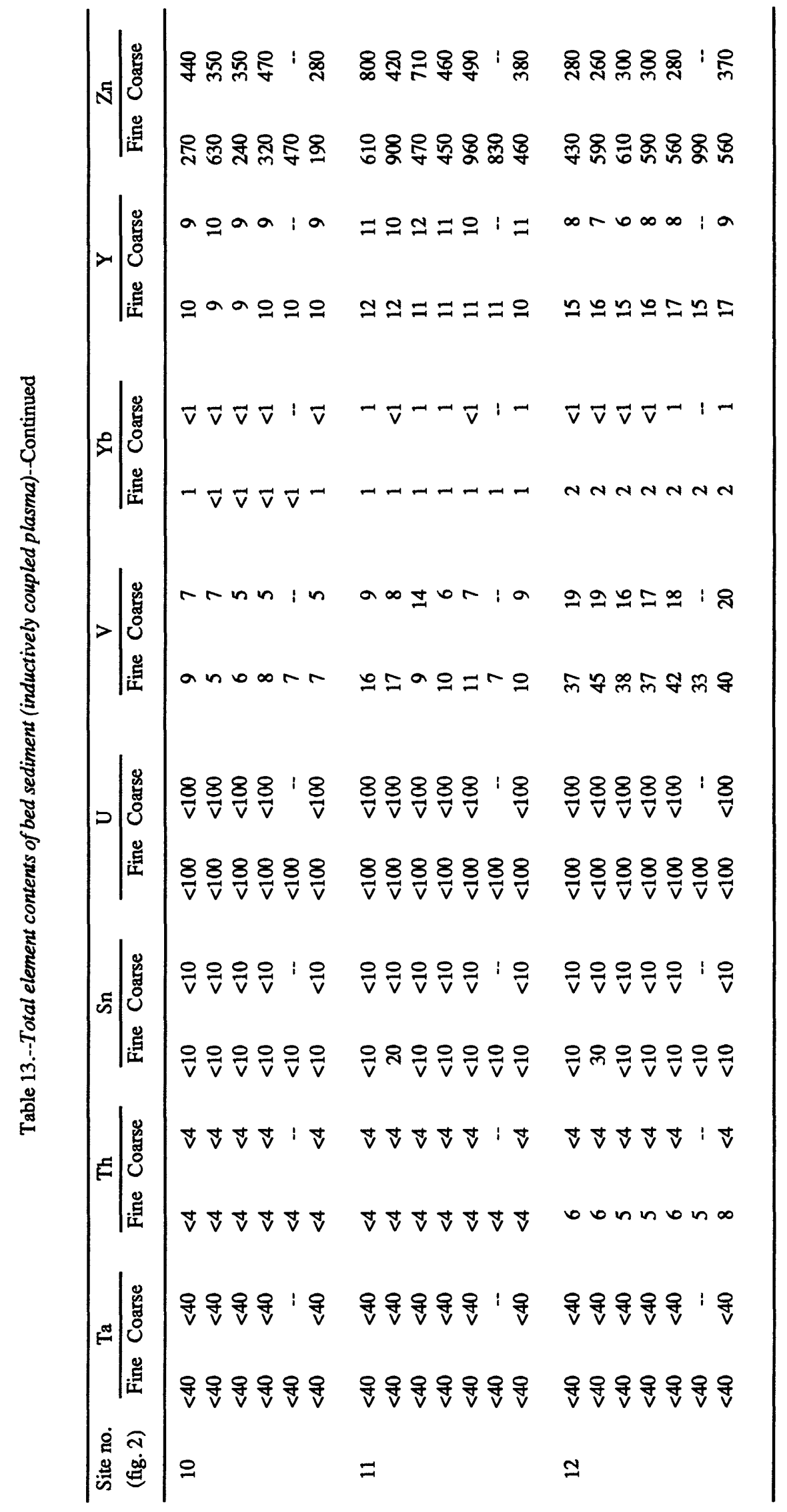




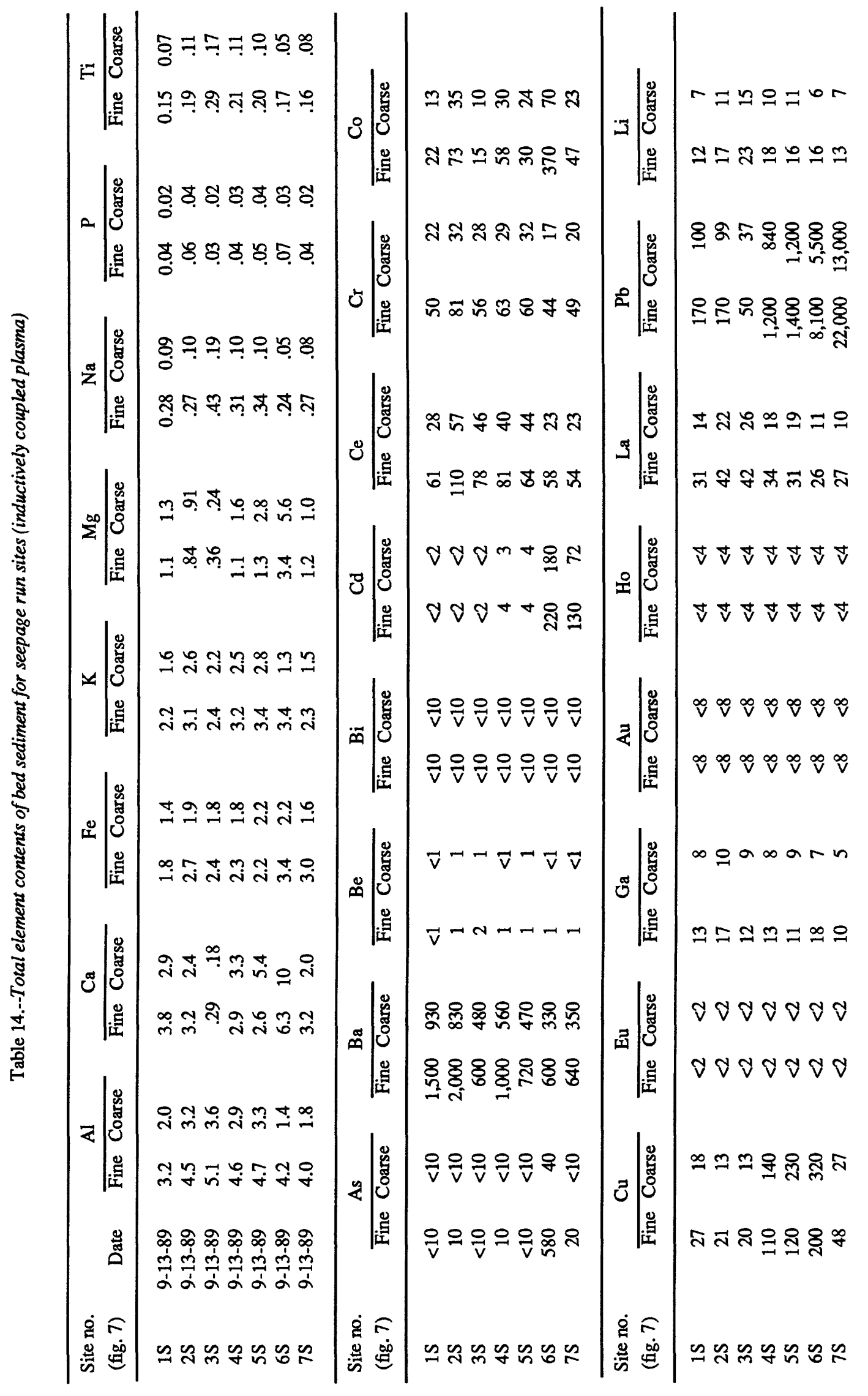




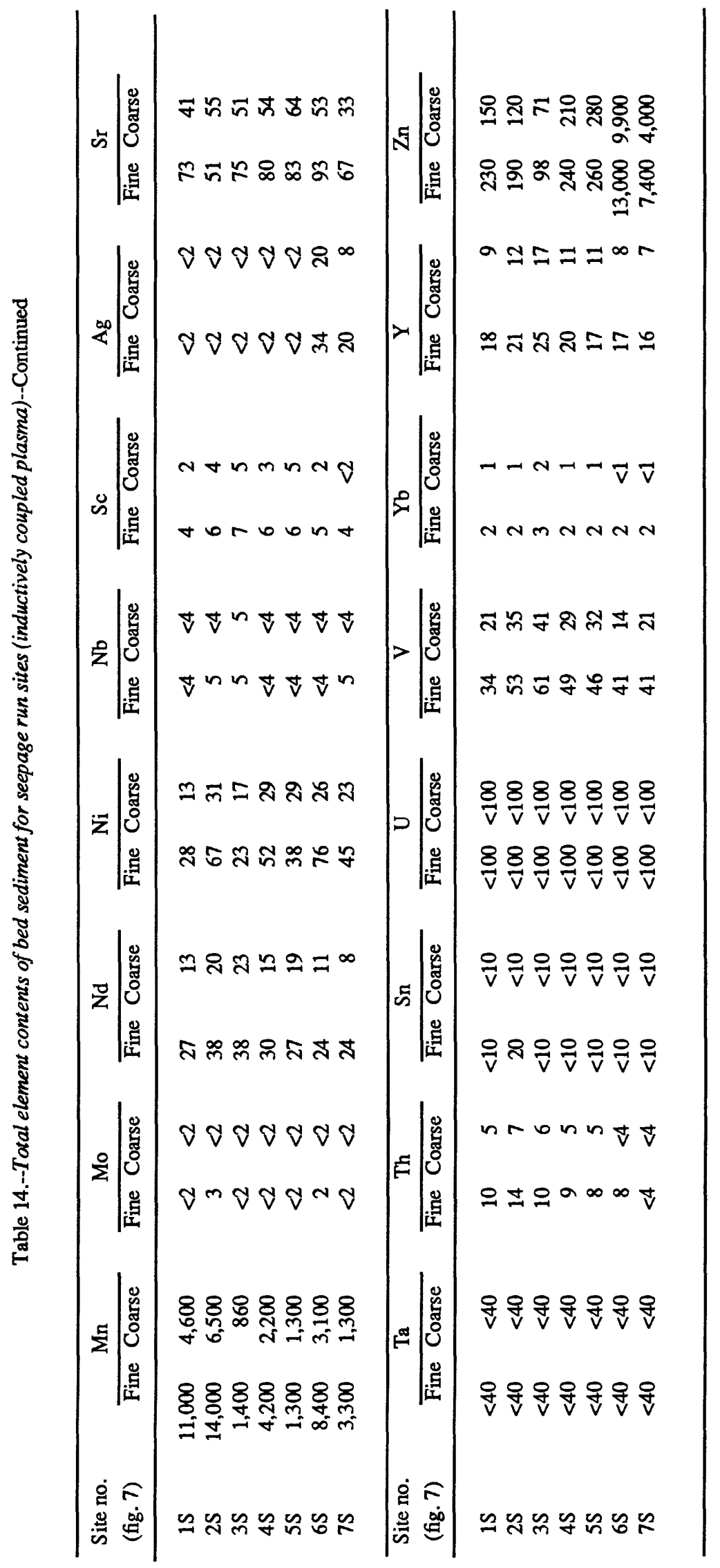




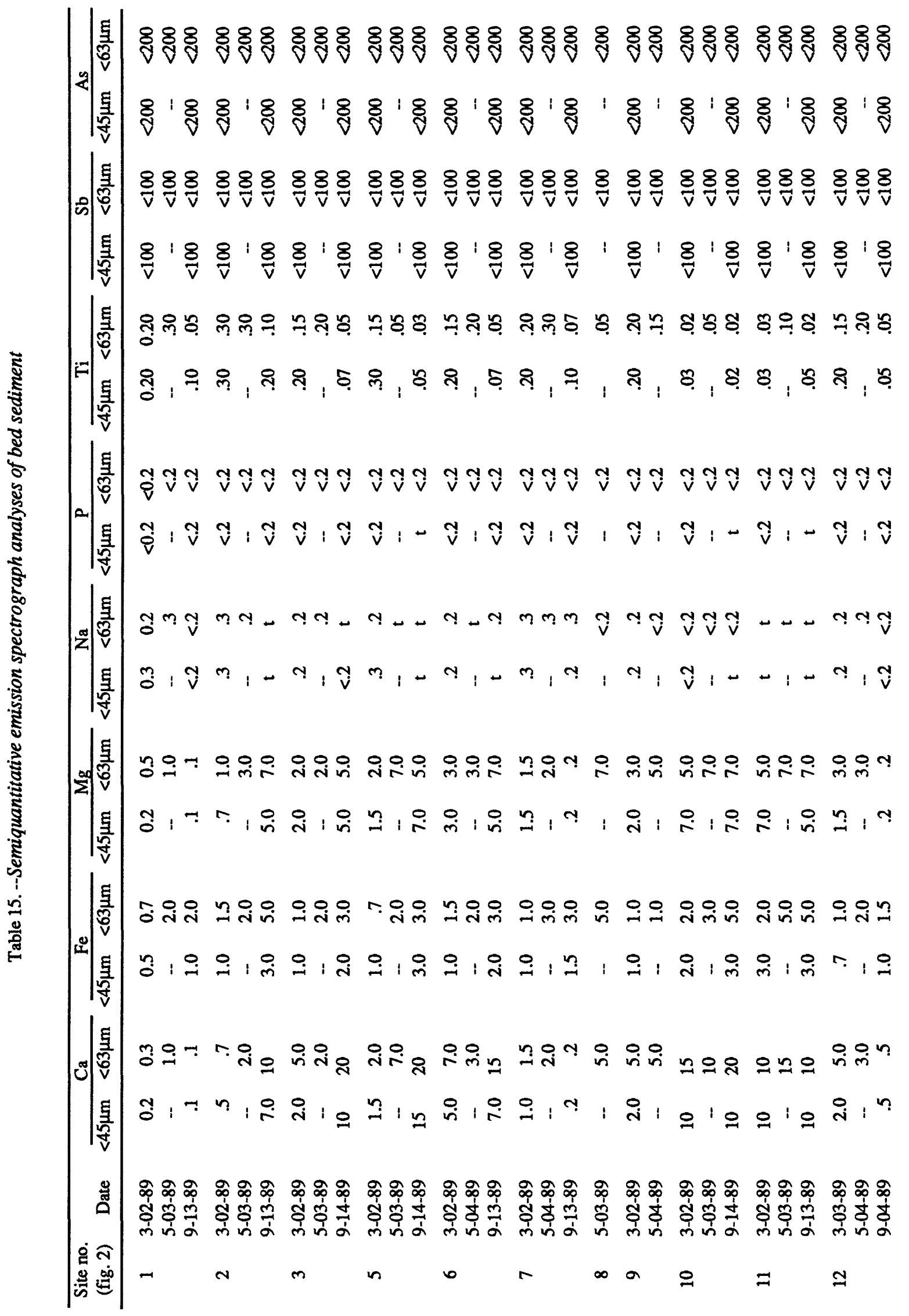




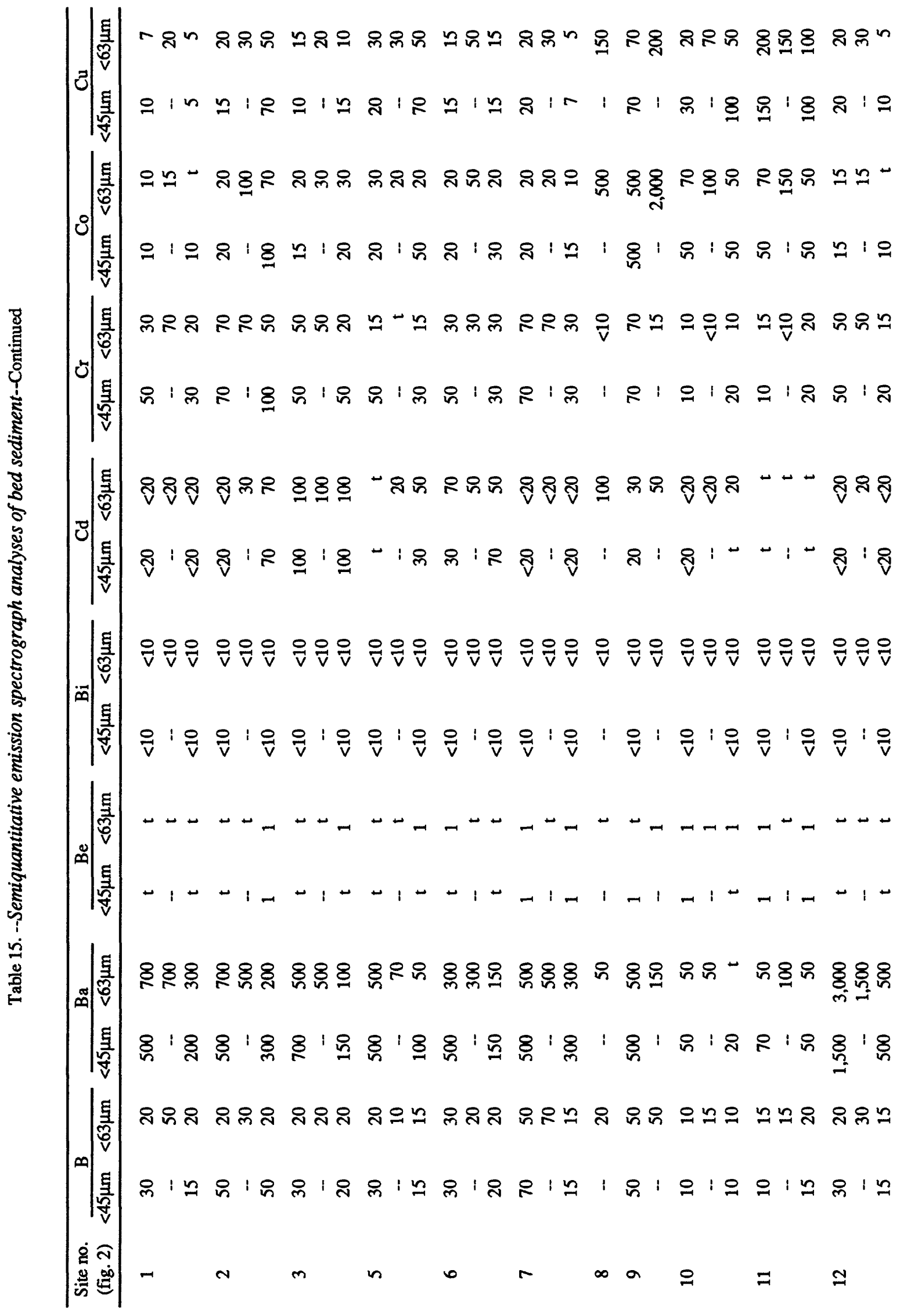




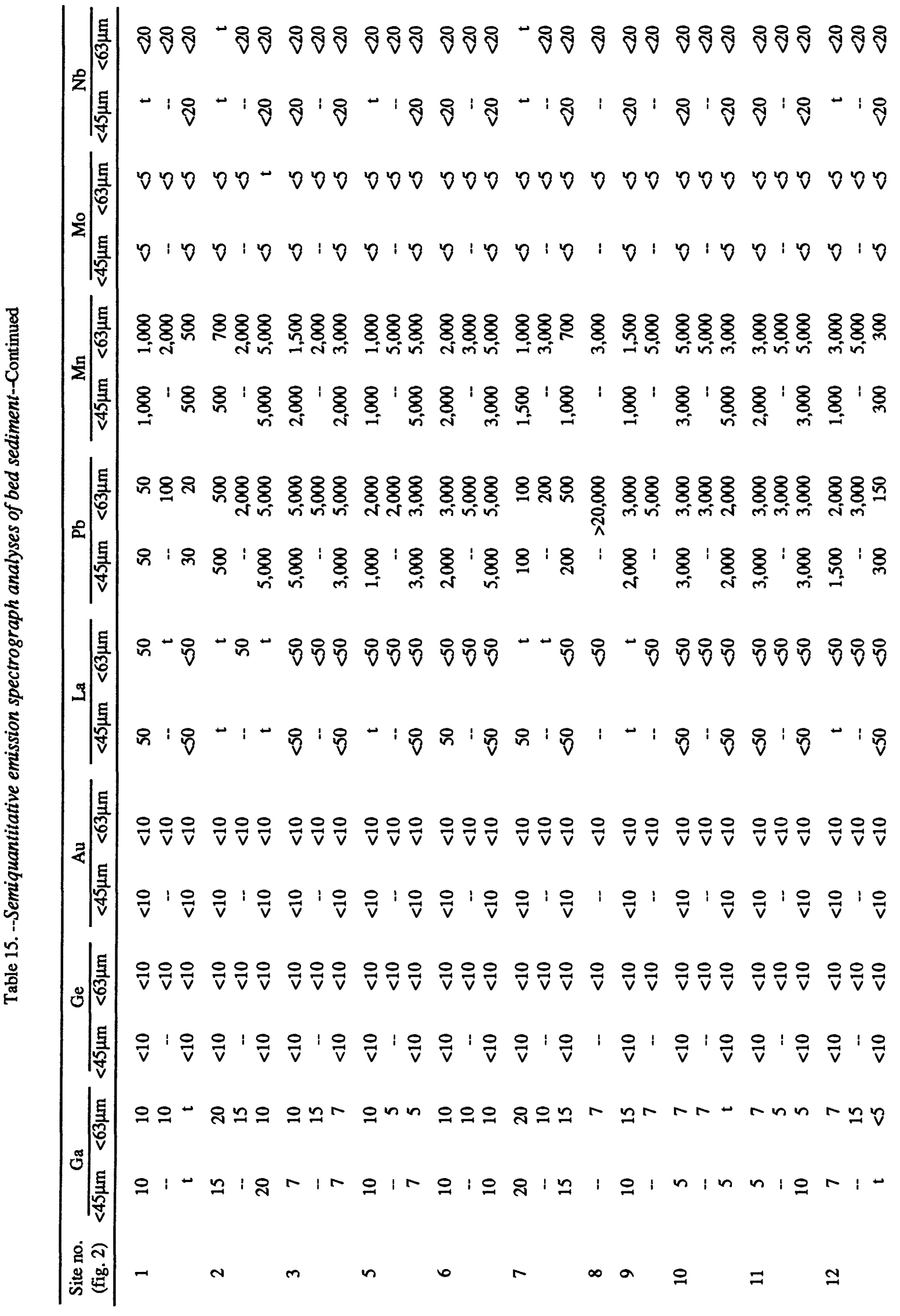




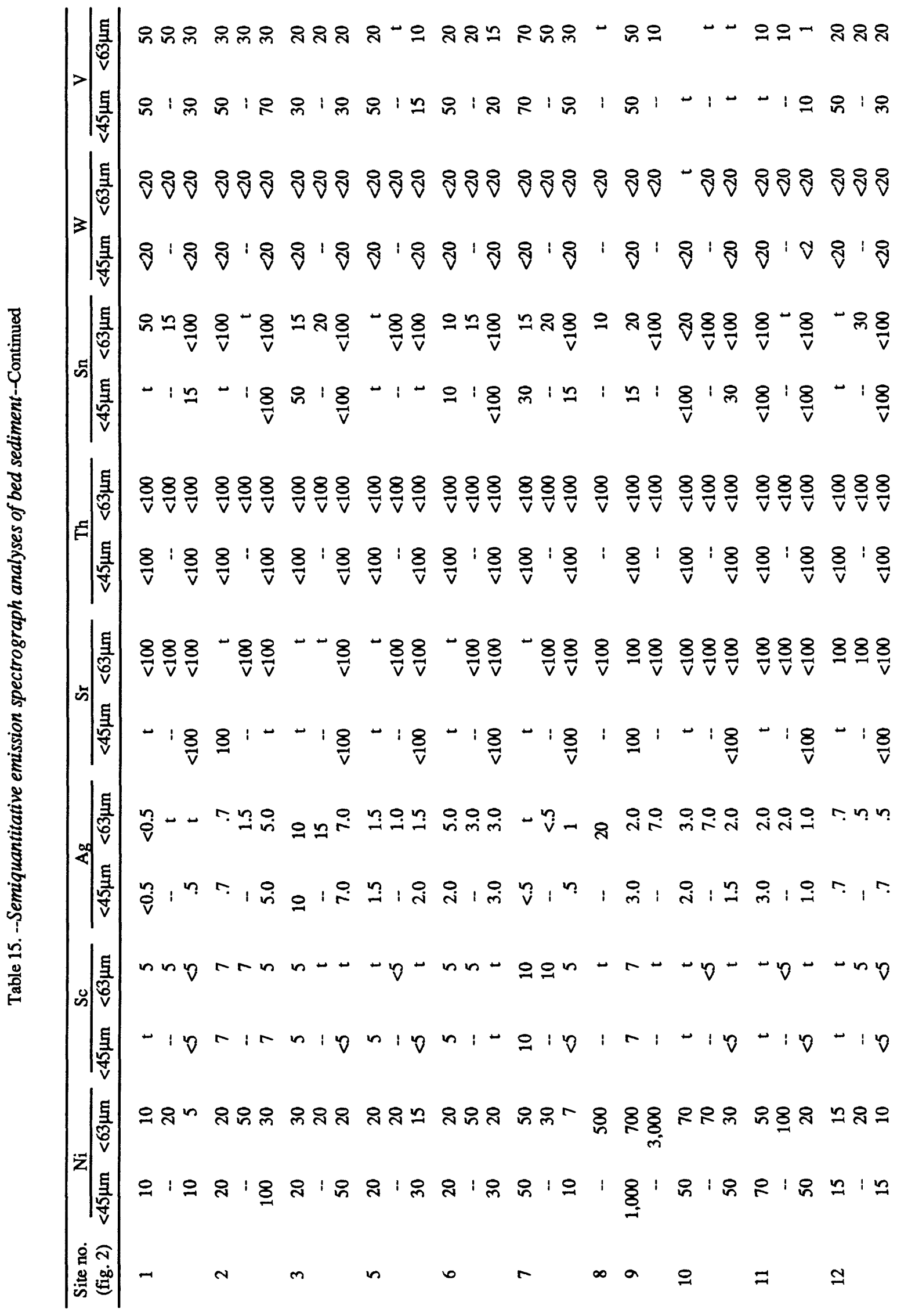




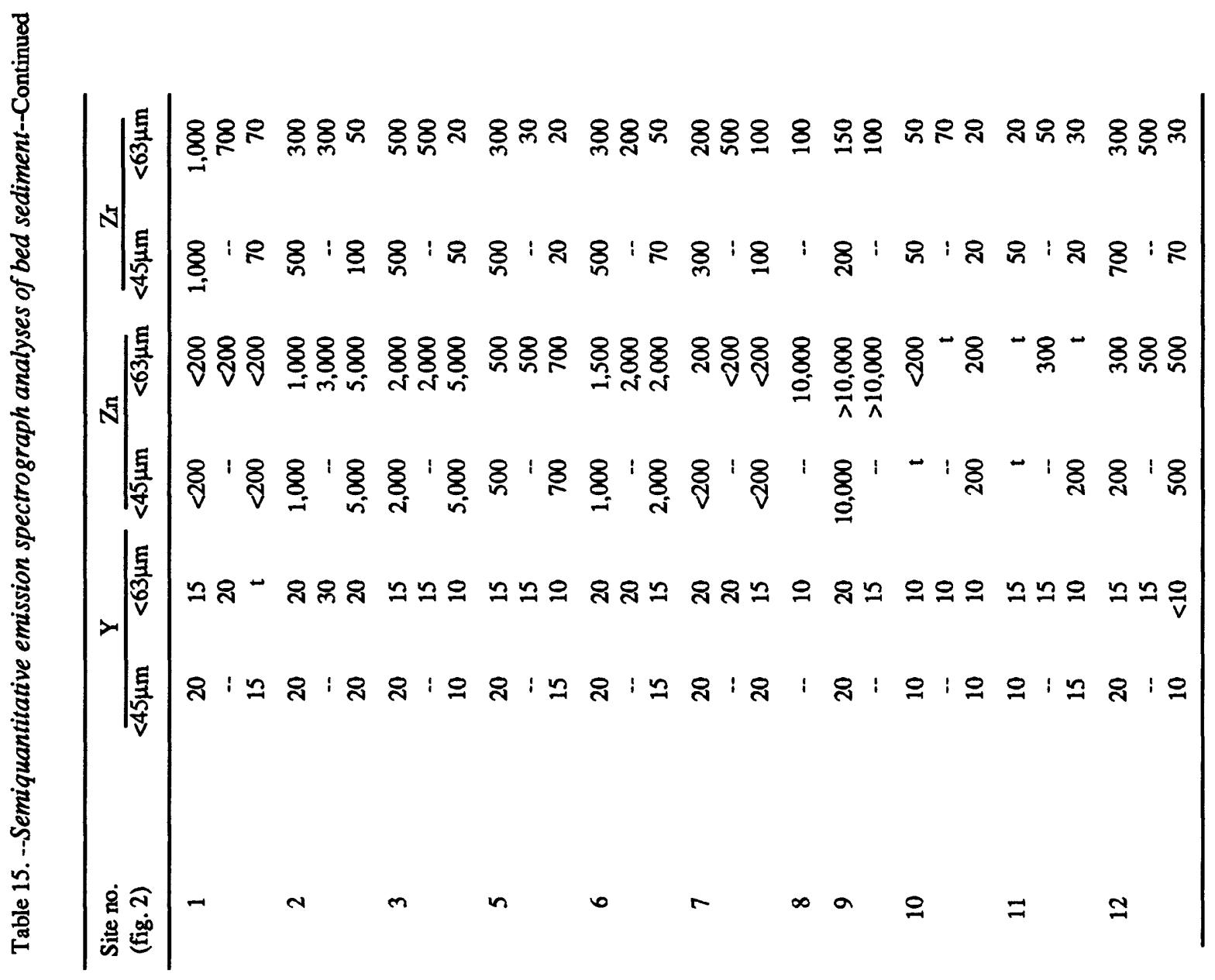




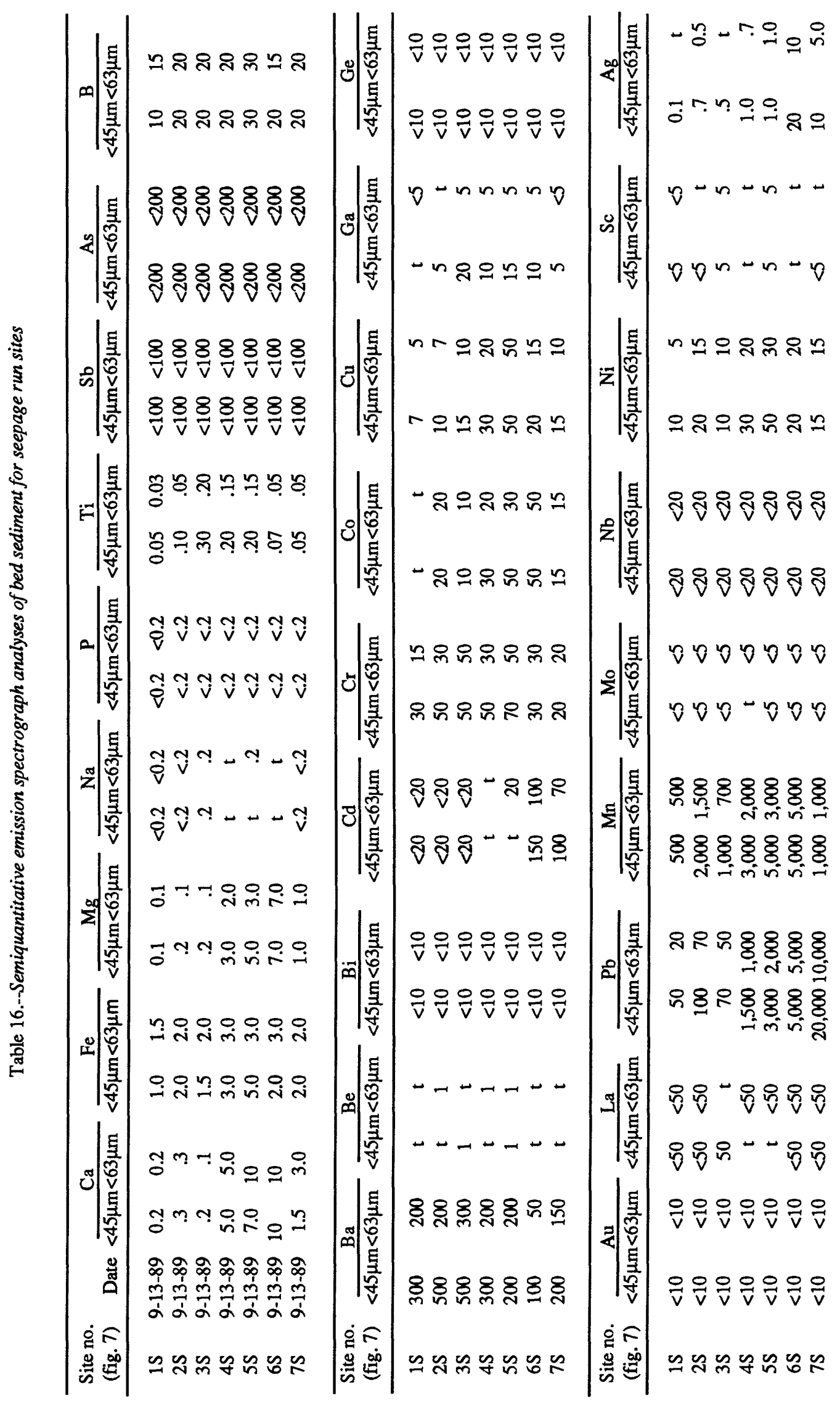




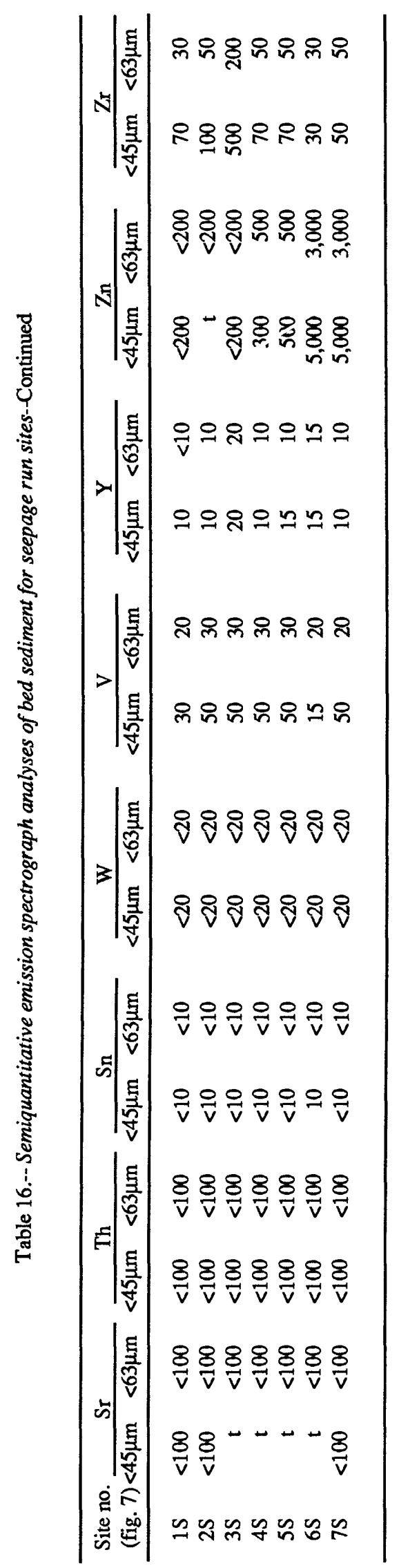




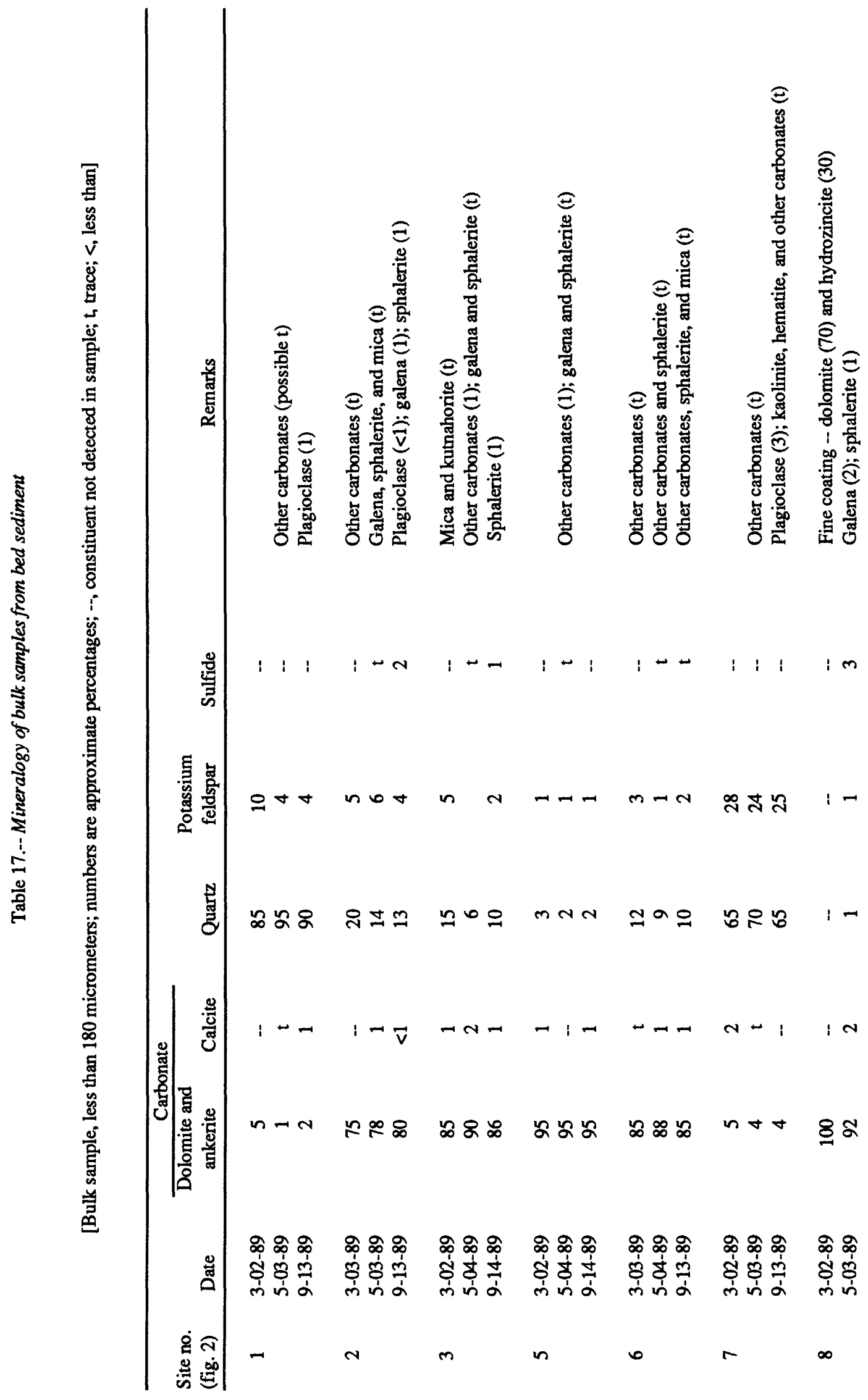




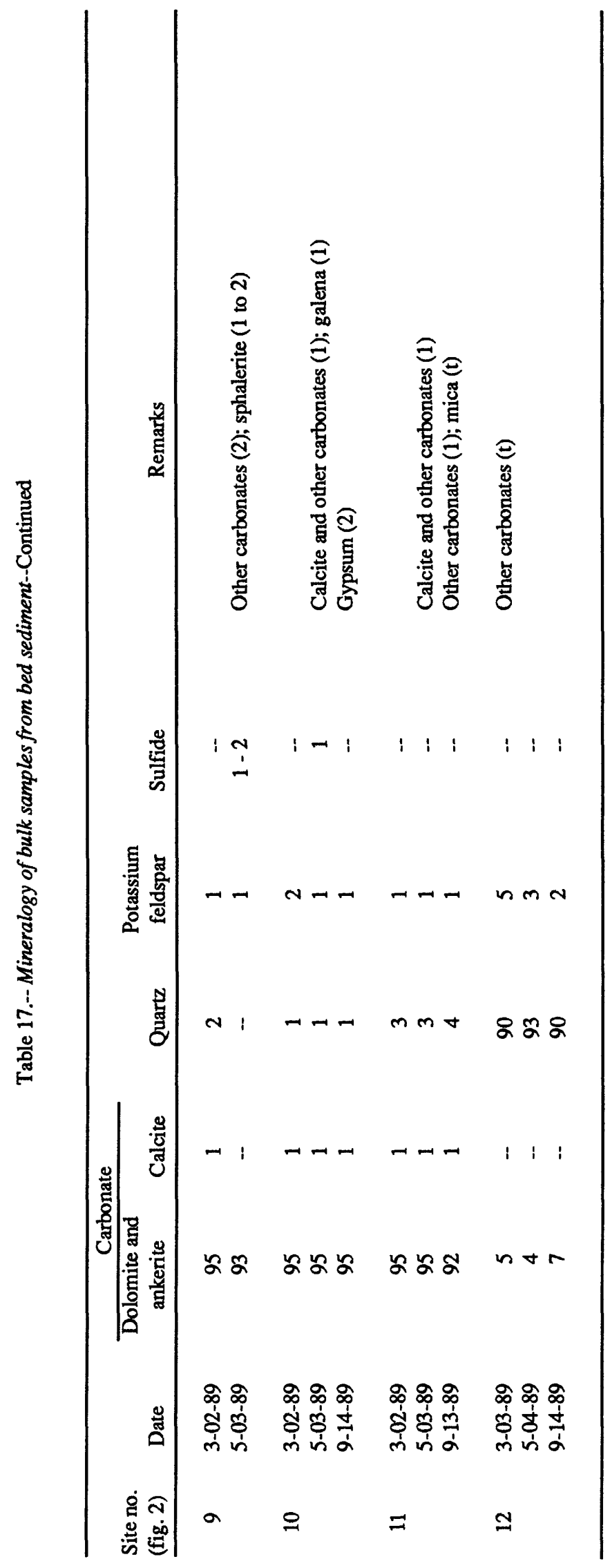




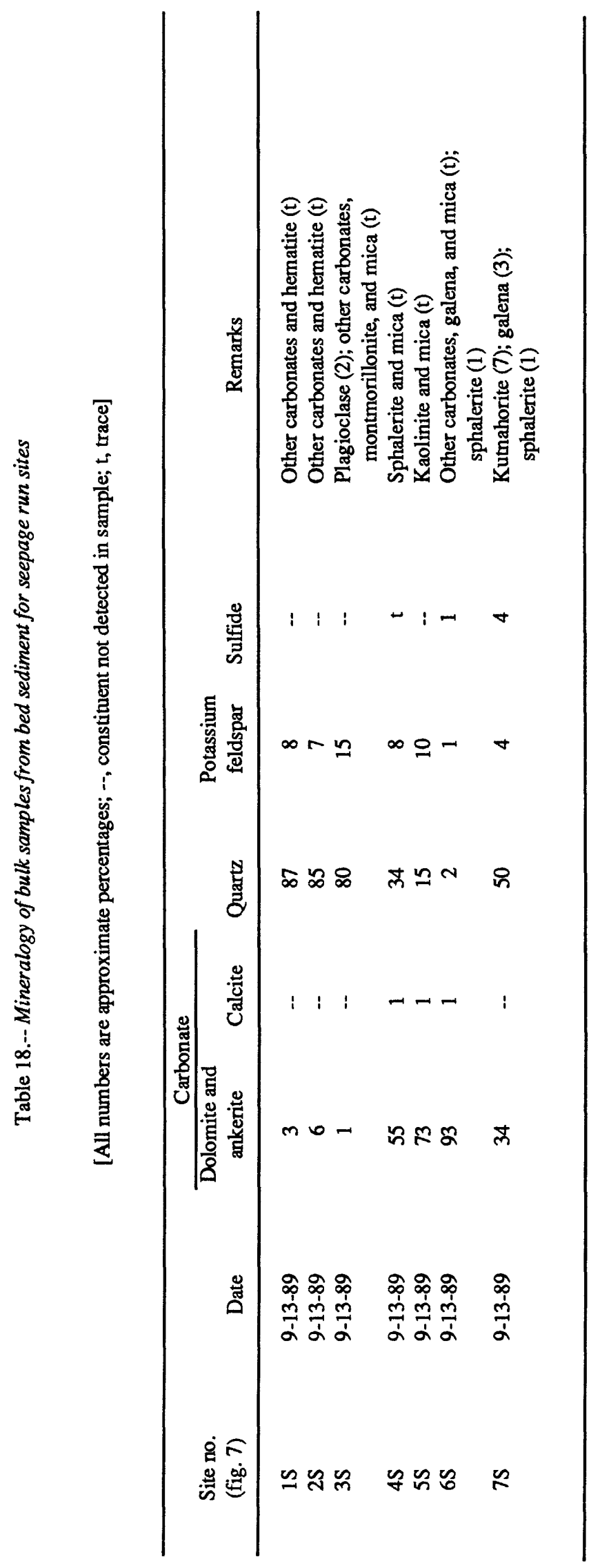


Table 19.-- Weight percentages of heavy mineral concentrates from bed sediment

[C-1 fraction, highly magnetic minerals; C-2 fraction, slightly magnetic mostly non-ore minerals; C-3 fraction, non-magnetic ore and non-ore minerals; <, less than]

\begin{tabular}{|c|c|c|c|c|}
\hline \multirow{2}{*}{$\begin{array}{l}\text { Site no. } \\
\text { (fig. 2) }\end{array}$} & \multirow[b]{2}{*}{ Date } & \multicolumn{3}{|c|}{ Weight percentage of heavy mineral concentrate } \\
\hline & & $\overline{\mathrm{C}-1}$ & $\mathrm{C}-2$ & C-3 \\
\hline \multirow[t]{2}{*}{1} & 3-02-89 & 4 & 86 & 10 \\
\hline & $5-03-89$ & 4 & 90 & 6 \\
\hline \multirow{2}{*}{2} & $3-03-89$ & $<1$ & 79 & 21 \\
\hline & $5-03-89$ & $<1$ & 46 & 53 \\
\hline \multirow[t]{2}{*}{3} & $3-02-89$ & 2 & 36 & 62 \\
\hline & $5-04-89$ & 4 & 13 & 83 \\
\hline \multirow[t]{2}{*}{5} & 3-02-89 & $<1$ & 100 & $<1$ \\
\hline & $5-04-89$ & $<1$ & 73 & 26 \\
\hline \multirow[t]{2}{*}{6} & 3-03-89 & $<1$ & 98 & 2 \\
\hline & $5-04-89$ & $<1$ & 81 & 18 \\
\hline \multirow[t]{2}{*}{7} & $3-02-89$ & 5 & 91 & 4 \\
\hline & $5-03-89$ & 6 & 88 & 5 \\
\hline 8 & $5-03-89$ & $<1$ & 53 & 47 \\
\hline \multirow[t]{2}{*}{9} & $3-02-89$ & $<1$ & 71 & 29 \\
\hline & $5-03-89$ & $<1$ & 50 & 50 \\
\hline \multirow[t]{2}{*}{10} & $3-02-89$ & $<1$ & 74 & 26 \\
\hline & $5-03-89$ & $<1$ & 62 & 38 \\
\hline \multirow[t]{2}{*}{11} & $3-02-89$ & $<1$ & 86 & 13 \\
\hline & $5-03-89$ & $<1$ & 82 & 18 \\
\hline 12 & $5-04-89$ & 2 & 74 & 24 \\
\hline
\end{tabular}




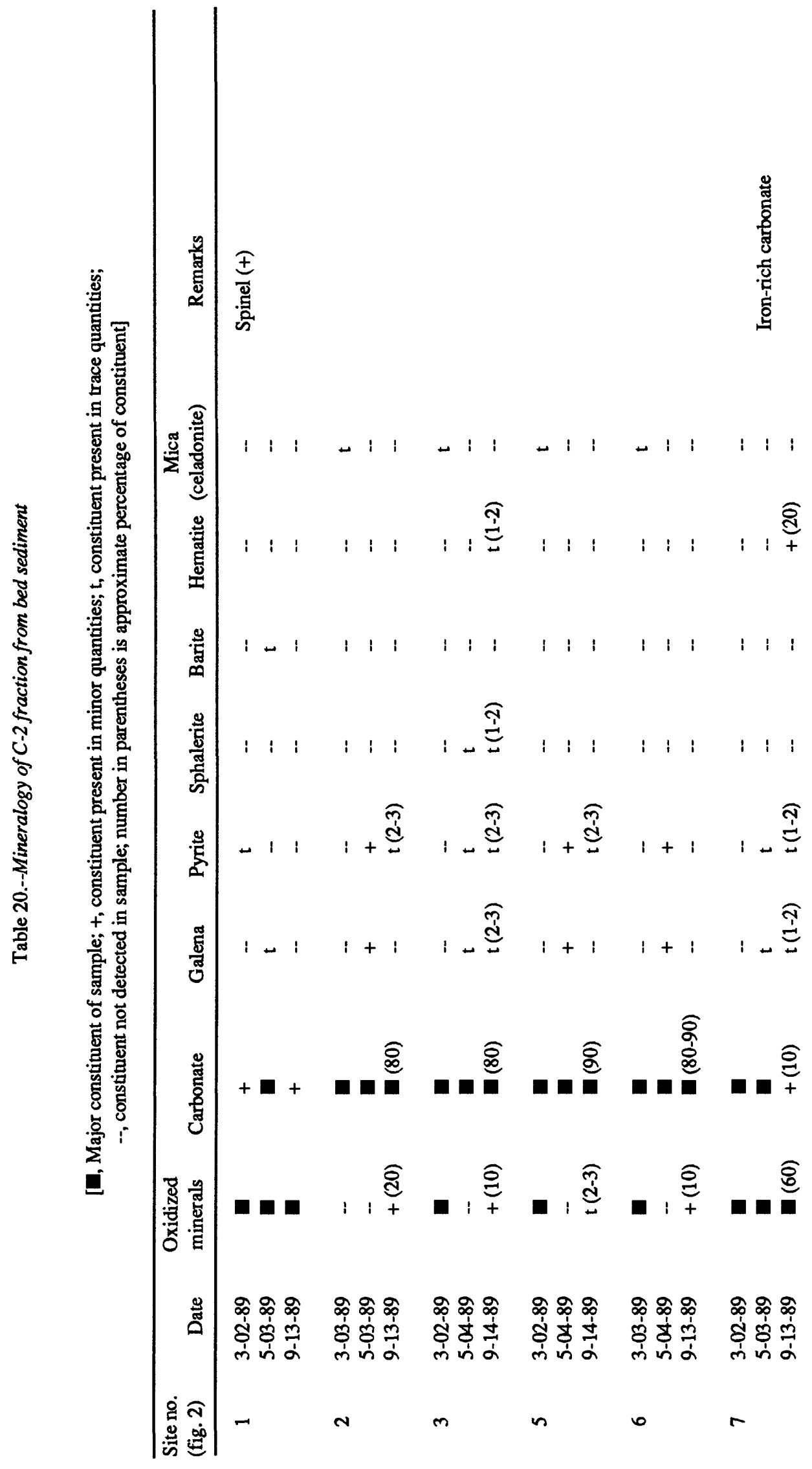




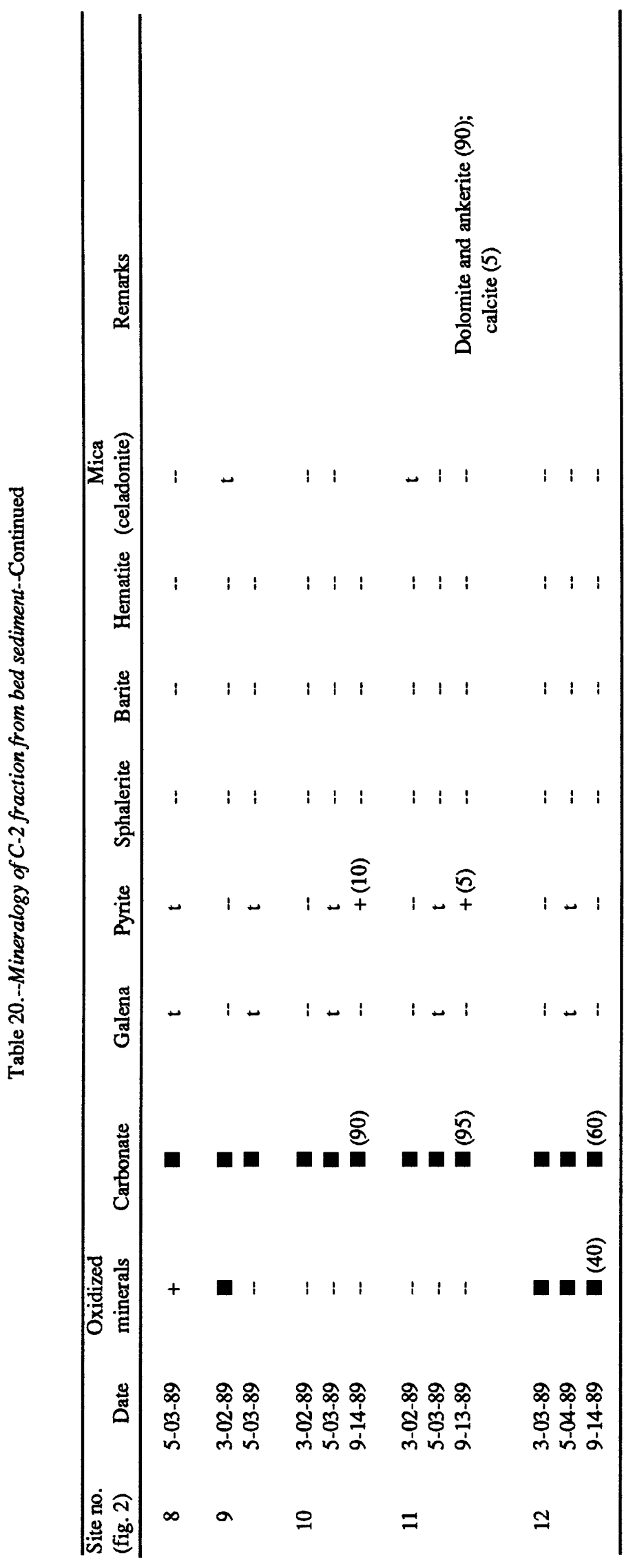

82 
Table 21.--Mineralogy of C-2 fraction from bed sediment for seepage run sites

[D, Major constituent of samples;,+ constituent present in minor quantities; $t$, constituent present in trace quantities; ,-- constituent not detected in sample; number in parentheses is approximate percentage of constituent]

\begin{tabular}{lrrrrrr}
\hline $\begin{array}{l}\text { Site no. } \\
\text { (fig. 7) }\end{array}$ & Date & $\begin{array}{l}\text { Oxidized } \\
\text { minerals }\end{array}$ & Carbonate & Galena & Pyrite & Hematite \\
\hline 1S & $9-13-89$ & $\mathbf{\square}(70)$ & $\mathbf{\square}(25)$ & -- & - & $\mathrm{t}(5)$ \\
$2 \mathrm{~S}$ & $9-13-89$ & $\mathbf{\square}(60)$ & $\mathbf{\square}(40)$ & - & - & $\mathrm{t}(2-3)$ \\
$3 \mathrm{~S}$ & $9-13-89$ & $\mathbf{\square}(80)$ & $+(20)$ & - & - & - \\
$4 \mathrm{~S}$ & $9-13-89$ & $+(15)$ & $\mathbf{\square}(80)$ & - & - & $\mathrm{t}$ \\
$5 \mathrm{~S}$ & $9-13-89$ & $+(20)$ & $\mathbf{\square}(80)$ & -- & - & - \\
$6 \mathrm{~S}$ & $9-13-89$ & $+(10)$ & $\mathbf{\square}(90)$ & -- & $\mathrm{t}(1-2)$ & - \\
$7 \mathrm{~S}$ & $9-13-89$ & $+(10)$ & $\mathbf{\square}(80)$ & $\mathrm{t}(2-3)$ & $\mathrm{t}(2-3)$ & - \\
& & & & & \\
\end{tabular}


TABLES 22 AND 23

\section{ABBREVIATIONS AND REPORTING UNITS FOR CHEMICAL CONSTITUENTS AND NOTATIONS USED IN TABLES}

$\mathrm{Ca}$

$\mathrm{Fe}$

Mg Magnesium, percent

$\mathrm{Na}$ Sodium, percent

P Phosphorus, percent

Ti Titanium, percent

$\mathrm{Sb}$ Antimony, in micrograms per gram

As Arsenic, in micrograms per gram

B Boron, in micrograms per gram

$\mathrm{Ba}$ Barium, in micrograms per gram

Be Beryllium, in micrograms per gram

$\mathrm{Bi}$ Bismuth, in micrograms per gram

Cd Cadmium, in micrograms per gram

Cr Chromium, in micrograms per gram

Co Cobalt, in micrograms per gram

$\mathrm{Cu}$ Copper, in micrograms per gram

$\mathrm{Ga}$ Gallium, in micrograms per gram

$\mathrm{Ge}$ Germanium, in micrograms per gram

An Gold, in micrograms per gram

La Lanthanum, in micrograms per gram
$\mathrm{Pb}$ Lead, in micrograms per gram

Mn Manganese, in micrograms per gram

Mo Molybdenum, in micrograms per gram

$\mathrm{Ni}$ Nickel, in micrograms per gram

$\mathrm{Nb}$ Niobium, in micrograms per gram

Sc Scandium, in micrograms per gram

Ag Silver, in micrograms per gram

Sr Strontium, in micrograms per gram

Th Thorium, in micrograms per gram

Sn Tin, in micrograms per gram

W Tungsten, in micrograms per gram

V Vanadium, in micrograms per gram

Y Ytrium, in micrograms per gram

$\mathrm{Zn} \quad \mathrm{Zinc}$, in micrograms per gram

$\mathrm{Zr}$ Zirconium, in micrograms per gram

$<\quad$ Less than

$\mathrm{t}$ Detected in trace quantities, but not quantifiable

$>\quad$ Greater than

>* Much greater than 


\begin{tabular}{|c|c|c|c|c|c|c|c|}
\hline$\vec{n}$ & $\mathbb{\nabla}^{-}$రి & రి శిర్వి & శ్రిర్రి & శิธిశ్ & ర్రి రి & ช్రి రి & ชิ \\
\hline 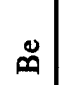 & $-\tilde{v}$ & 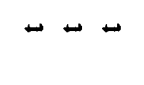 & $\nabla \nabla^{-}$ & $-\nabla \nabla$ & $-\omega$ & $-\nabla \nabla$ & 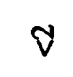 \\
\hline 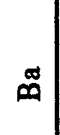 & $\begin{array}{ll}8 & 8 \\
8 & 8 \\
0 & 8 \\
0 & 0 \\
0 & 0\end{array}$ & ్ి유유 & 윰용요 & \&్ల & ర్లి \&్తి \&్సి & 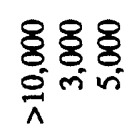 & in \\
\hline$\infty$ & \&్స \&్లి & శి & శి & ¿ి $^{-}$ & 주 లి శి & శి గి గి & i \\
\hline z & 8 & 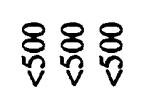 & 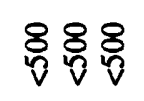 & 8.0 & 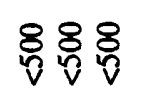 & 8 & 8 \\
\hline के & $88^{-}$ & \&్రిళ్రి & ళ్రి త్రి త్రి & \&్రి & ఫ్రి ర్రి & 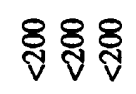 & \& \\
\hline$\dot{F}$ & 우요 & ฮุర & రి రి & 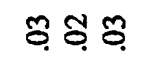 & ธิธ ช. \% & ำ & ธุ. \\
\hline$\infty$ & $\tilde{z}-\tilde{v}$ & ชุด & ทุด & $\mathfrak{v} \vartheta$ & 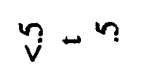 & $n-\eta$ & $\mathfrak{v}$ \\
\hline$z^{\pi}$ & nิ? & 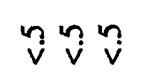 & 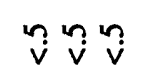 & $\mathfrak{v} \vartheta$ & 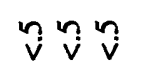 & ที่ง & $\eta$ \\
\hline$\sum_{\Sigma}^{\infty}$ & 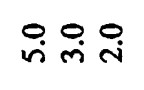 & 웃요 & ㅁำ & 웃욤요 & 으요 & $\dot{m} \ddot{m} \dot{m}$ & $\dot{i}$ \\
\hline 必 & 유요요 & 우요으 & 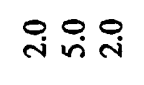 & 울옹 & 울요 & 오오 & i \\
\hline లే & 일뵤 & 욷요 & 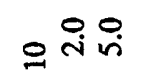 & صن요 & $\cong \simeq \cong$ & 욤요 & $\stackrel{ }{i}$ \\
\hline ڤัّ & 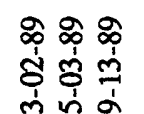 & 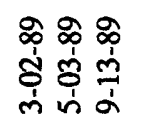 & 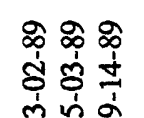 & 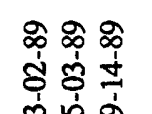 & 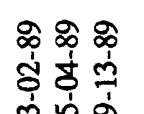 & 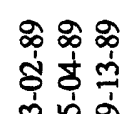 & के \\
\hline 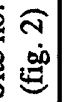 & - & $N$ & $m$ & $n$ & 0 & r & 。 \\
\hline
\end{tabular}




\begin{tabular}{|c|c|c|c|c|c|c|c|}
\hline$z$ & 어용 & 융ำ & 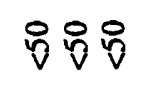 & 888 & 888 & 8 묵 & 8 \\
\hline$\dot{z}$ & 용ㅇ & ㅇㅇㅁ & ํํํำ & ళ్తి \&్సి & 8 응 & ళ్లి & 8 \\
\hline$\stackrel{0}{\Sigma}$ & $\frac{O}{v} \frac{O}{v} \vec{v}$ & $\stackrel{\partial}{\vec{v}} \stackrel{\mathrm{V}}{\mathrm{v}} \frac{\mathrm{v}}{\mathrm{v}}$ & 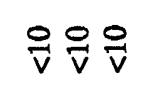 & 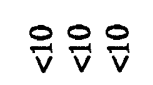 & 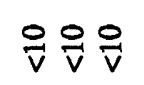 & 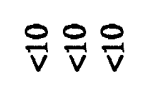 & $\frac{O}{v}$ \\
\hline$\frac{5}{2}$ & $\begin{array}{l}8888 \\
80 \\
\text { nivivi }\end{array}$ & 88 & ర్రి & 8088 & $\begin{array}{l}8888 \\
\text { nis }\end{array}$ & 8888 & $\underset{8}{8}$ \\
\hline \& & 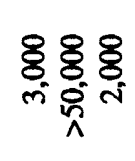 & 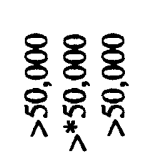 & 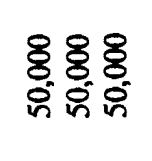 & 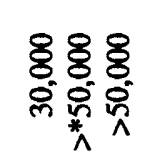 & 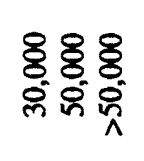 & 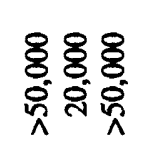 & 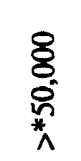 \\
\hline$\Xi$ & ్ㅣ맥유 & $\underset{v}{g} \frac{g}{v} \frac{\delta}{v}$ & $\frac{g}{v} \frac{8}{v} \frac{8}{v}$ & $\frac{\delta}{v} \frac{8}{v} \frac{\delta}{v}$ & $\frac{8}{v} \frac{8}{v} \frac{8}{v}$ & $8^{-}$\&్ల & $\frac{8}{\vec{v}}$ \\
\hline$z$ & శ్రి రి & రి రి రి & రిశ్రి & ర్రి రి & ర్రిర్రి & ర్రి రి & రి \\
\hline 0 & క్రి రి & $\mathbb{\nabla}^{--}$ & రి & రి & జ్రిర్రి & ర్రిర్రి & శ్రి \\
\hline రో & 우 - & $\frac{9}{v} \cong$ & శిరి & 옹ㅇㅇㅇ & -ュㅇ & $-\infty$ & $\stackrel{O}{\vec{v}}$ \\
\hline z & 88 & 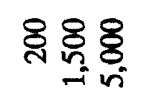 & ిత్రి్సి & $\begin{array}{l}8 \\
\end{array}$ & 용 & 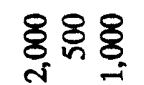 & ஜ \\
\hline 8 & 요 \&్ర & 요욤음 & 요욤 & ళ & 요용 & 8) & ஜ \\
\hline$\breve{u}$ & 串号 & ర్లి ్ָరి & ర్రి & ర్రి ్రి & ర్రి & గిగి & จิ \\
\hline$\Xi$ & 요윰유 & 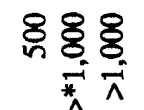 & 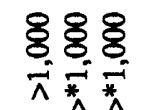 & 8 & 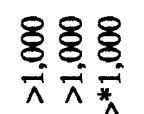 & 응요 & 8 \\
\hline 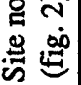 & - & $N$ & $m$ & $n$ & 0 & - & \\
\hline
\end{tabular}




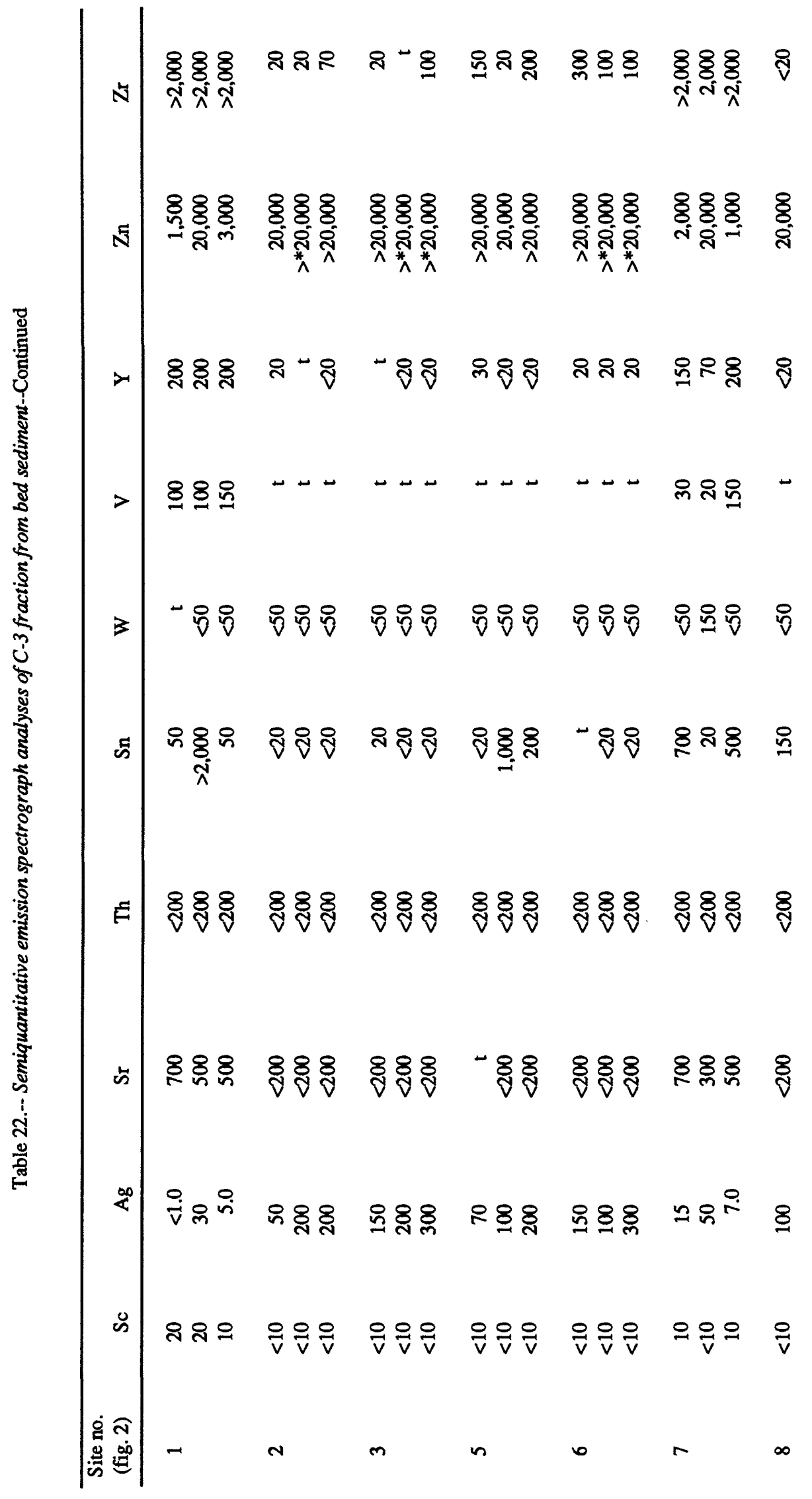




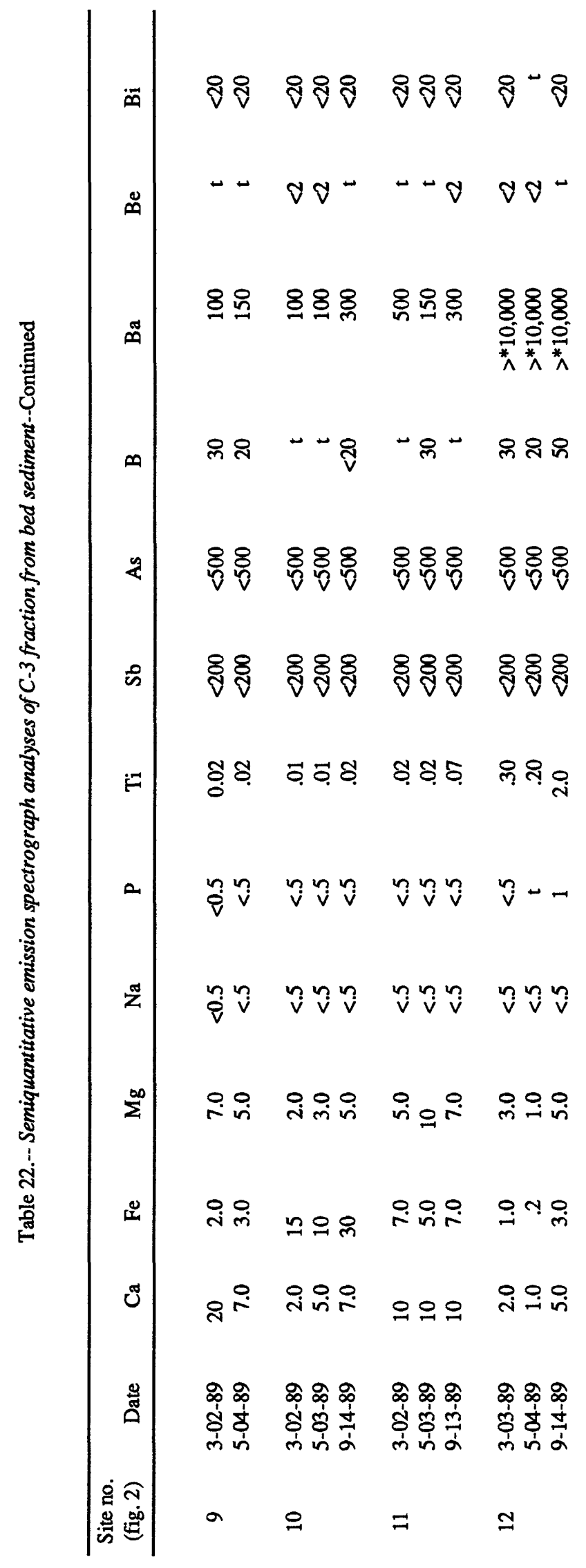




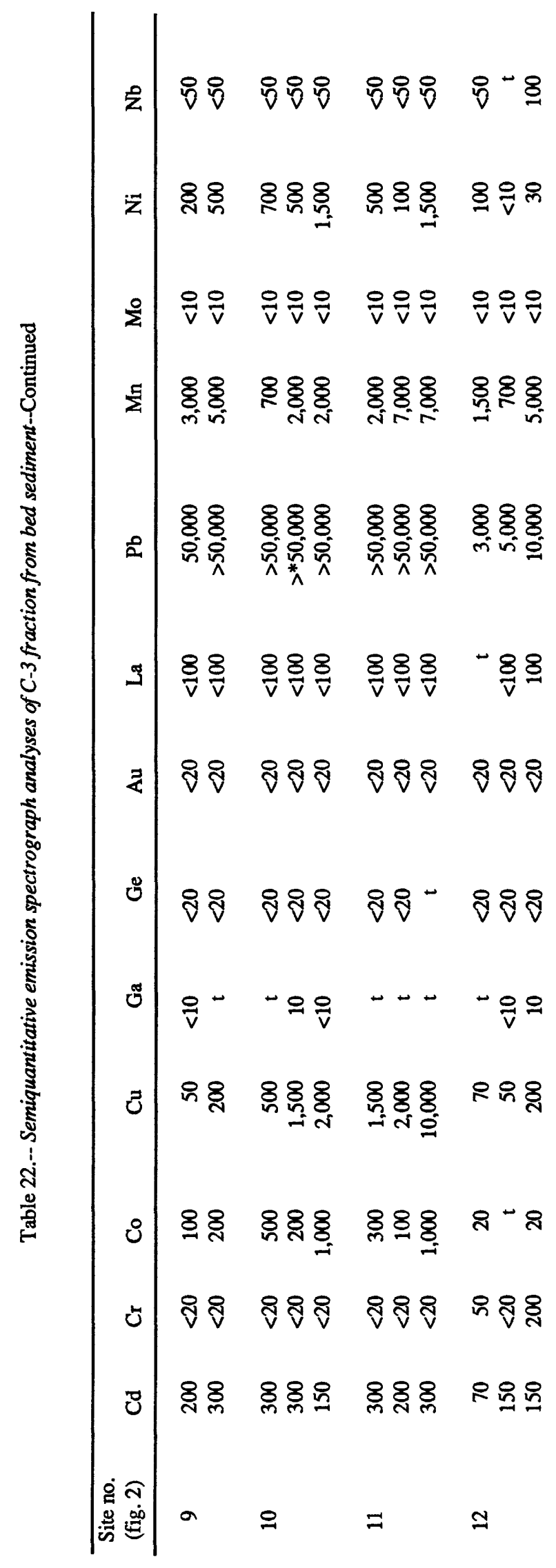




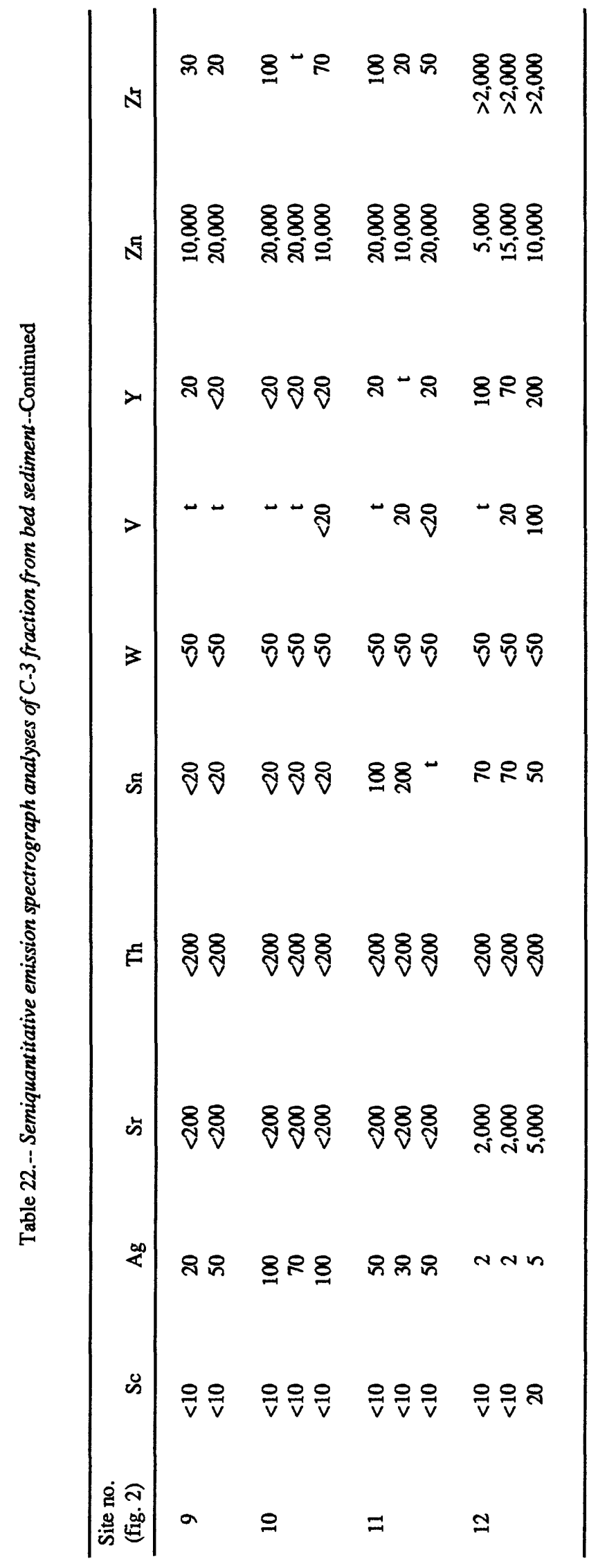




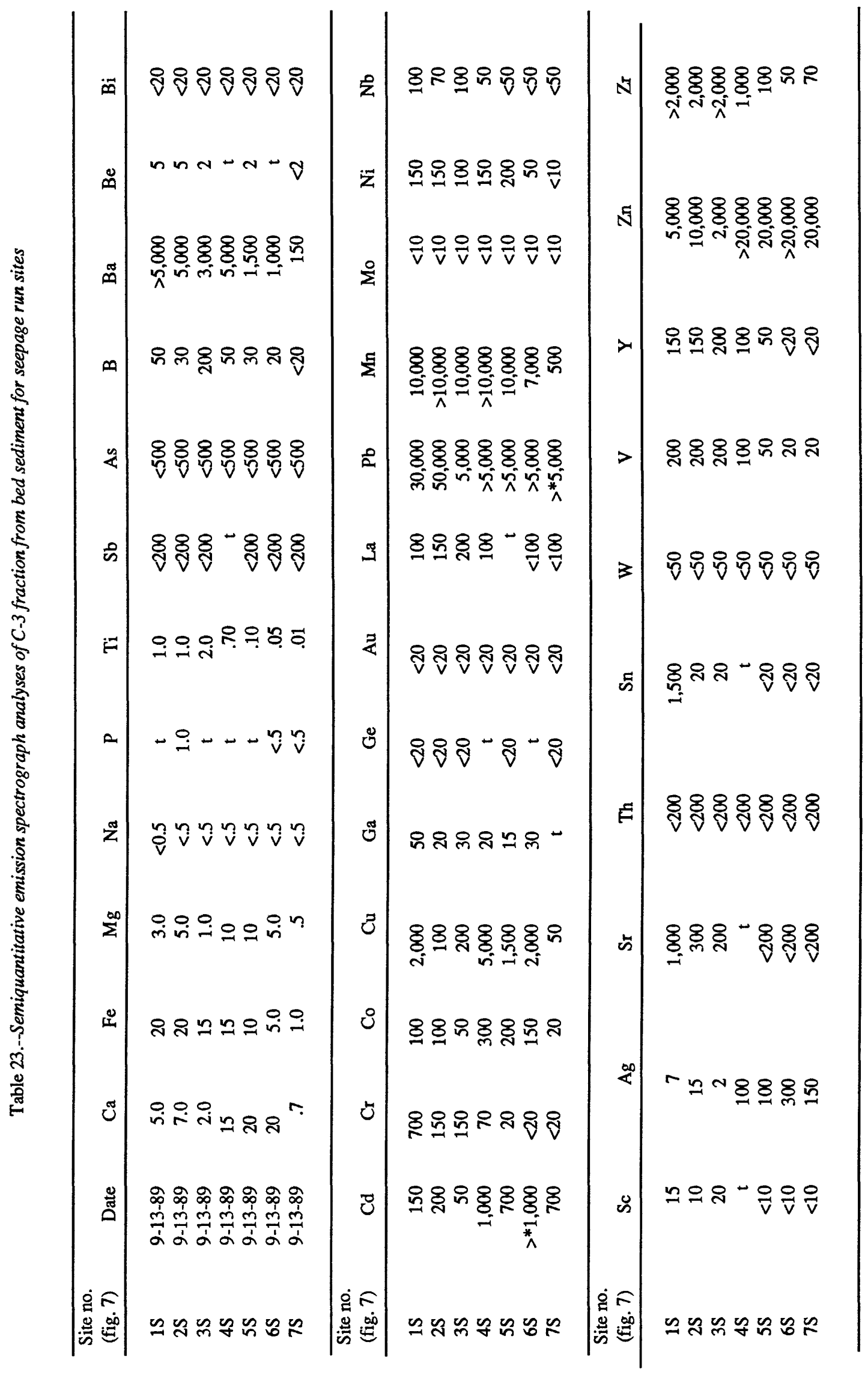




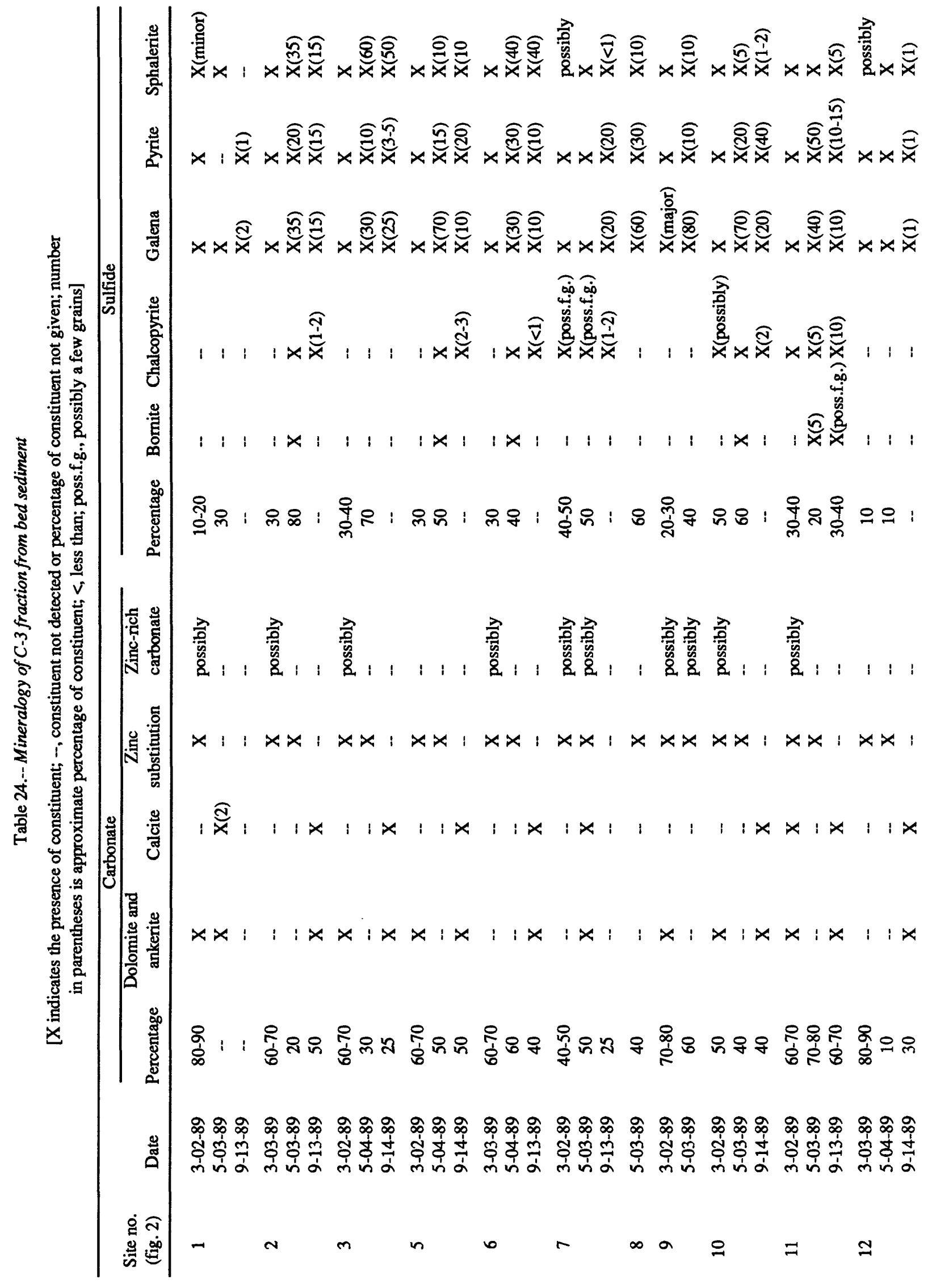




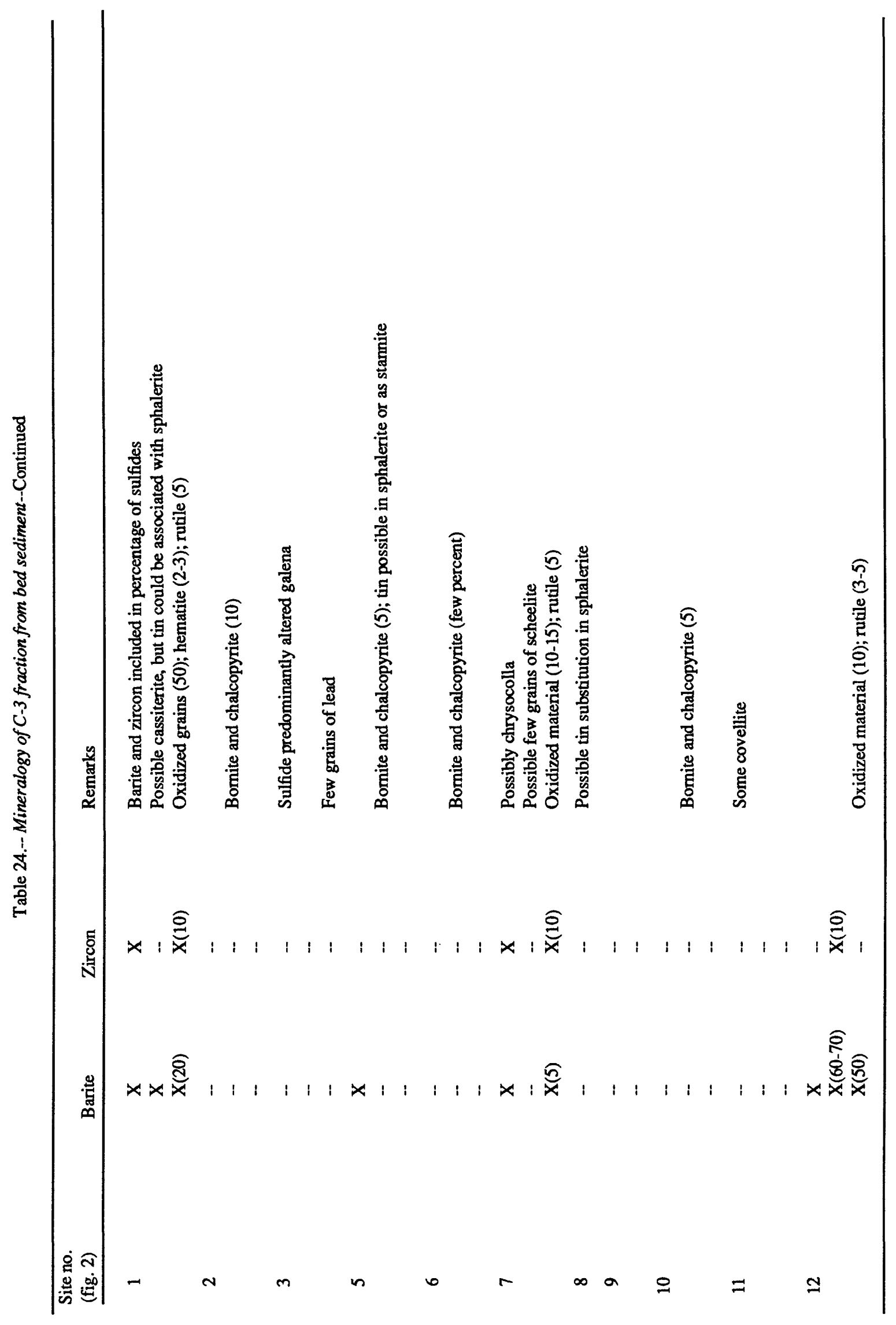




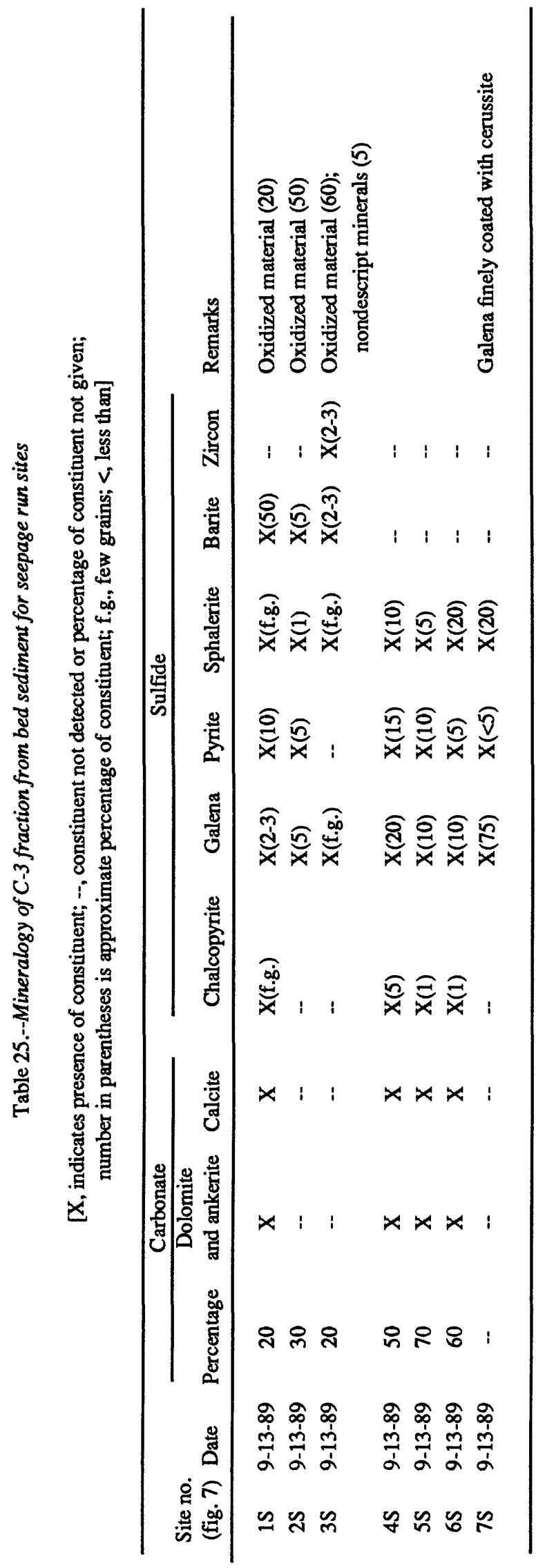




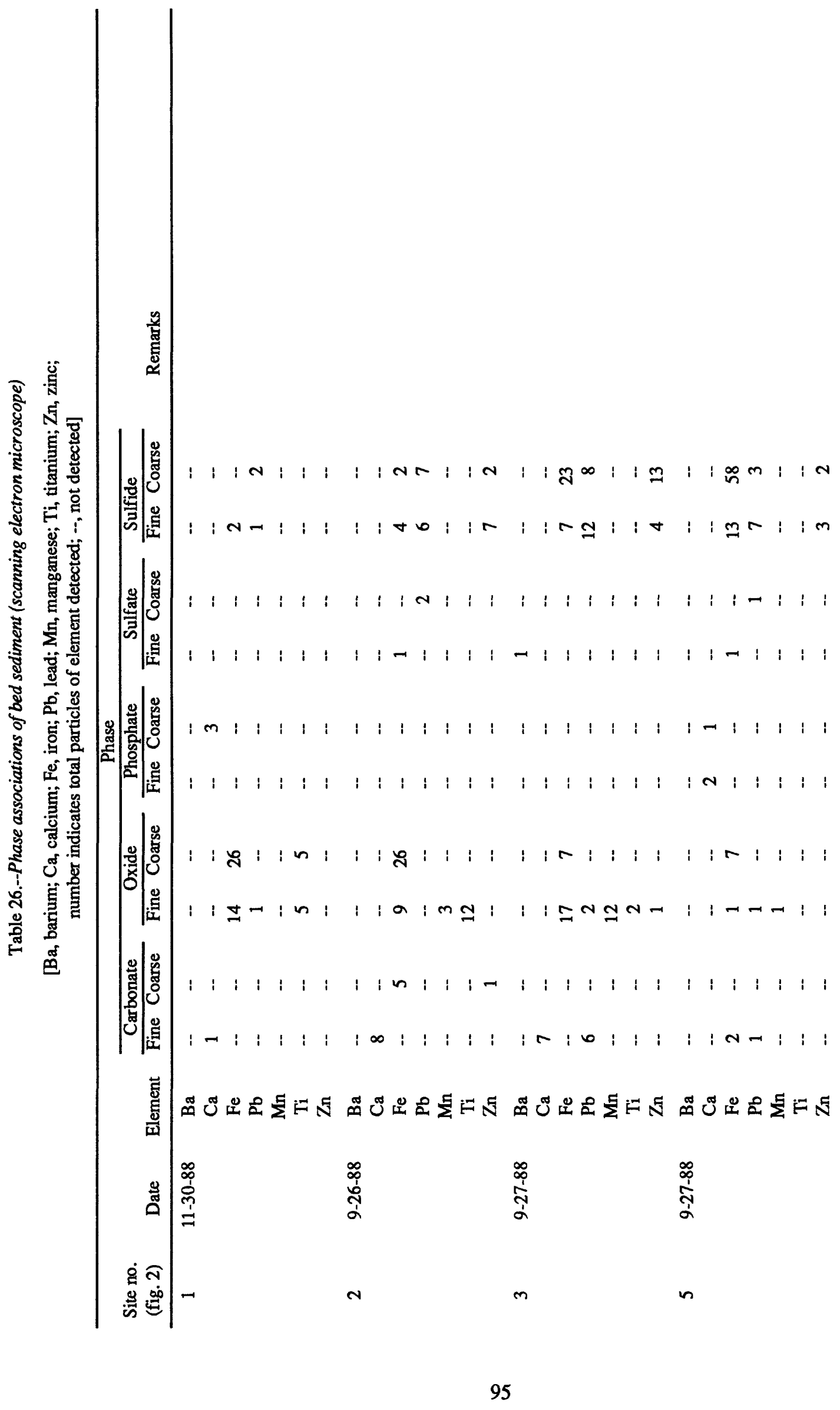




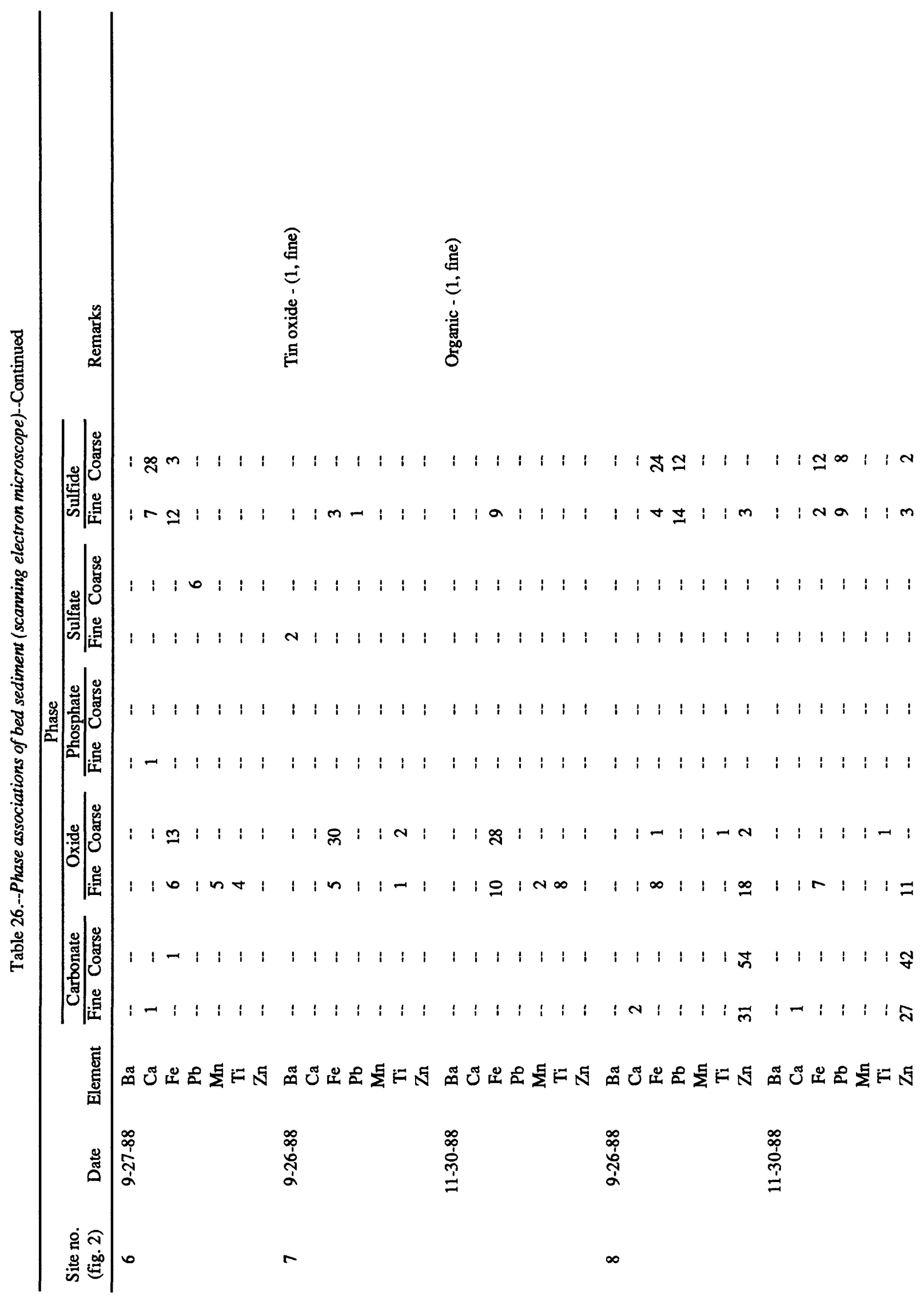




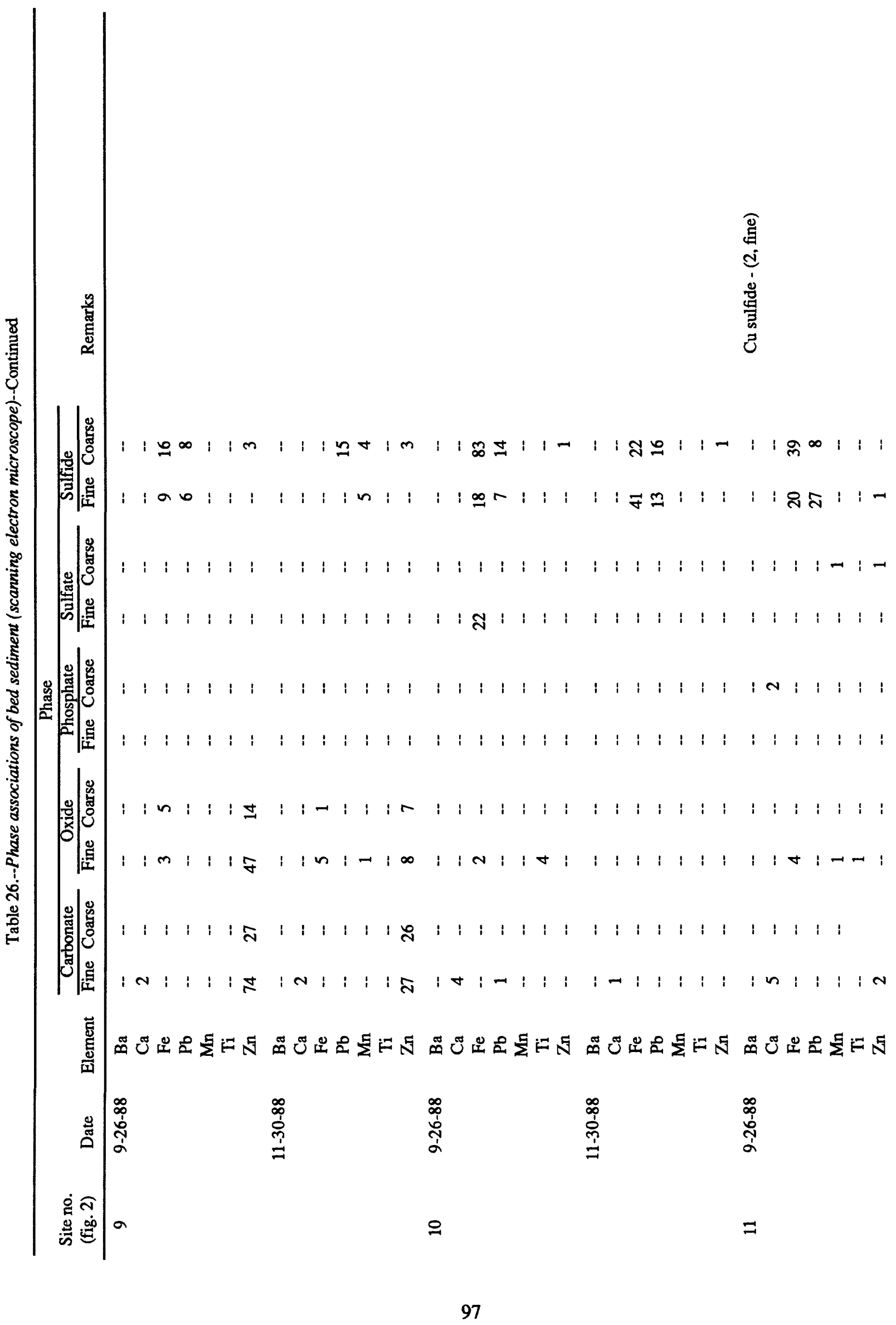




$$
L
$$

